\title{
La fórmula para el sacramento de la comunión en lengua mochica
}

\author{
José ANTONio Salas García*
}

\section{RESUMEN}

El presente artículo tiene por objeto traducir del mochica al castellano la fórmula utilizada para administrar el sacramento de la comunión. Como acontece con otros textos mochicas que hemos tenido ocasión de interpretar (Salas García 2008), los resultados de la traducción nos muestran textos que no son exactamente iguales en su contenido a las versiones de estas oraciones en castellano.

Palabras Clave: lengua mochica, traducción, textos cristianos

* Agradezco al doctor Rodolfo Cerrón-Palomino por haber leído el original de este artículo y por las gentiles sugerencias que me hizo. No obstante, los errores que pudieran subsistir son de mi entera responsabilidad. 


\section{INTRODUCCIÓN}

El extinto idioma mochica se habló en la sierra de Piura, en pueblos de Cajamarca, en todo Lambayeque y en La Libertad, posiblemente hasta Moche. En el siglo XVII, el gramático Fernando de la Carrera (1644: sin numeración) ${ }^{1}$ brinda la distribución de los pueblos de habla mochica en cuatro corregimientos, detallando qué orden religiosa estaba a cargo de cada pueblo. Así, para el corregimiento de Trujillo se menciona que el pueblo de Santiago de Cao corresponde a la orden de Santo Domingo, mientras que Magdalena de Cao, Chocope, todo el valle de Chicama y Paiján estaban bajo la Orden Mercedaria. Si bien la información del siglo XVII proporcionada por De la Carrera no menciona la ciudad de Trujillo ni el valle de Moche como un centro de habla mochica, se cuenta con información del siglo anterior que nos hace pensar que durante el siglo XVI el mochica también se habló en dicho valle. En efecto, esto nos lo comunica Gonzalo Fernández de Oviedo (1855 [1557]: 224-225):

En otras ochenta ó noventa leguas que hay desde aqueste rio hasta la villa de Truxillo hay otras lenguas que llaman mochicas, é las mugeres que visten como las de Tumbez, é los indios camisetas é pañicos y en las cabeças unas madexas de lana hilada colorada é muy fina, una vuelta desde á la cabeça y echado su barbiquexo: é traen todos unas mantas por capas, porque tienen por afrenta andar sin ellas, é los

1. Las páginas de la primera parte del Arte de la lengua yunga de Fernando de la Carrera no cuentan con numeración. 
señores se sirven de mucho arte. Tienen sus pages é sus offiçiales é coçineros, todos hombres, no mugeres: andan en hamacas: si no es en la lengua, en todo lo demás, en trage, en serviçio, en sacrifiçios é çeremonias todos acuerdan en una cosa.

Fernández de Oviedo da un indicio de que estaríamos ante la misma entidad lingüística cuando escribe (1851 [1535]: 448): «En la tierra llana llaman á este animal col, é en la sierra le diçen llama [...]». El término col es plenamente mochica. Este no es el único indicio que nos hace pensar que el mochica se hablaba hasta Trujillo. En la Relación anónima de costumbres antiguas de los naturales del Perú (Jesuita Anónimo 1968 [1594]: 169) se habla de las autoridades religiosas prehispánicas y se menciona que en cada localidad importante existía un prelado, y se detalla que se requería para «los Muchicas, otro, cuyo asiento era la huaca grande que está en Trujillo, que los naturales llaman Chimo». Estos indicios nos hacen pensar que en el siglo X'r se hablaba el mochica en Trujillo, cosa que al parecer no sucedió en el siglo siguiente, a juzgar por la distribución de pueblos de habla mochica que menciona Fernando de la Carrera.

Continuando con De la Carrera, este anota que en el corregimiento de Zaña, los pueblos de San Pedro de Lloc, Jequetepeque, Chepén, Guadalupe y Pueblo Nuevo corresponden a la orden de San Agustín. Por su parte, las localidades de Eten, Chiclayo y San Miguel eran de la orden de San Francisco, en tanto que Santa Lucía, parroquía de Zaña, Reque, Monsefú, Mochumí, Lambayeque, Túcume, Íllimo, Pacora, Mórrope y Jayanca pertenecían a clérigos. 
José Antonio Salas Garcia

En el corregimiento de Piura, el autor señala que Motupe, Guancabamba, el anexo de Penachi - conocido como Salas-y Copis, anexo de Olmos, eran de clérigos, mientras que el pueblo de Frías estaba a cargo de la Orden de La Merced.

En el corregimiento de Cajamarca hace mención de los pueblos de Santa Cruz, Niepos, San Miguel de la Sierra, San Pablo, e incluso de una parcialidad de Balsas de Marañón, como curatos de habla mochica asignados a la orden de San Francisco. Del mismo modo, se menciona a Cachen como pueblo de los mercedarios. Asimismo, se hace alusión a pueblos de la provincia de Huambos y del valle de Condebamba, donde se habla mochica y que eran curatos de clérigos. En total, De la Carrera calculaba que en estas localidades existían alrededor de cuarenta mil almas que hablaban la lengua mochica (1644).

El Arte de la lengua yunga de Fernando de la Carrera es la única gramática mochica que ha llegado a nosotros. Sin embargo, dicho autor no sería el único gramático colonial que se ocupó de este idioma. Jorge Zevallos Quiñones (1948) proporciona información de otros gramáticos cuyas obras no han llegado hasta nuestros días. El primero de ellos sería fray Pedro de Aparicio, quien hacia 1553 habría compuesto un arte, un vocabulario, sermones, pláticas y oraciones cristianas en la lengua de los habitantes del valle de Chicama (Zevallos Quiñones 1948: 43). El segundo gramático de quien da noticias Zevallos Quiñones es Alonso Núñez de San Pedro, el cual confiesa en una carta de 1595 que ha compuesto un catecismo y un arte de la lengua yunga (Zevallos Quiñones 1948: 44). Presumimos que Núñez de San Pedro escribió acerca de la misma lengua mochica que 
aparece en el arte de Fernando de la Carrera, pues dicho sacerdote era cura de Motupe y se sabe también que anduvo por Jayanca. Ambos pueblos eran, a la sazón, de habla mochica, lo cual sirve como base a nuestra presunción. Núñez de San Pedro manifiesta en la carta de 1595 que tenía veinte años de experiencia en las parroquias de la costa norte, por lo que sus obras podrían ser posteriores a 1575 y anteriores a la fecha de la carta.

El tercer gramático sería Roque Cejuela de Traña, cura de Lambayeque, que tradujo la Doctrina christiana a la lengua de sus feligreses de acuerdo con lo estipulado en el concilio de 1583. Cejuela confiesa que este trabajo le demandó cuatro años (Zevallos Quiñones 1948: 45). Se sabe que Lambayeque era de habla mochica. El cuarto gramático del cual se tiene noticias es Luis de Teruel, de quien se conoce que hacia 1618 se encontraba haciendo un arte y vocabulario de la lengua del pueblo de Lambayeque (Zevallos Quiñones 1948: 46). El quinto es Pedro Prado y Escobar. Zevallos Quiñones nos permite saber que este cura vivió desde 1623 a 1630 en Jayanca, zona de habla mochica. Prado y Escobar posiblemente escribió un arte de la lengua mochica (Zevallos Quiñones 1948: 49). El sexto gramático que menciona Zevallos Quiñones es Fernando de la Carrera, quien inicia la elaboración de una gramática mochica luego de 1633, año en que llega a San Martín de Reque como cura. La gramática se editará recién en 1644. A estos datos habría que añadirles que existe un conjunto de oraciones cristianas que fueron publicadas por Oré (1607). Con las informaciones recabadas presentamos el siguiente cuadro a manera de resumen: 


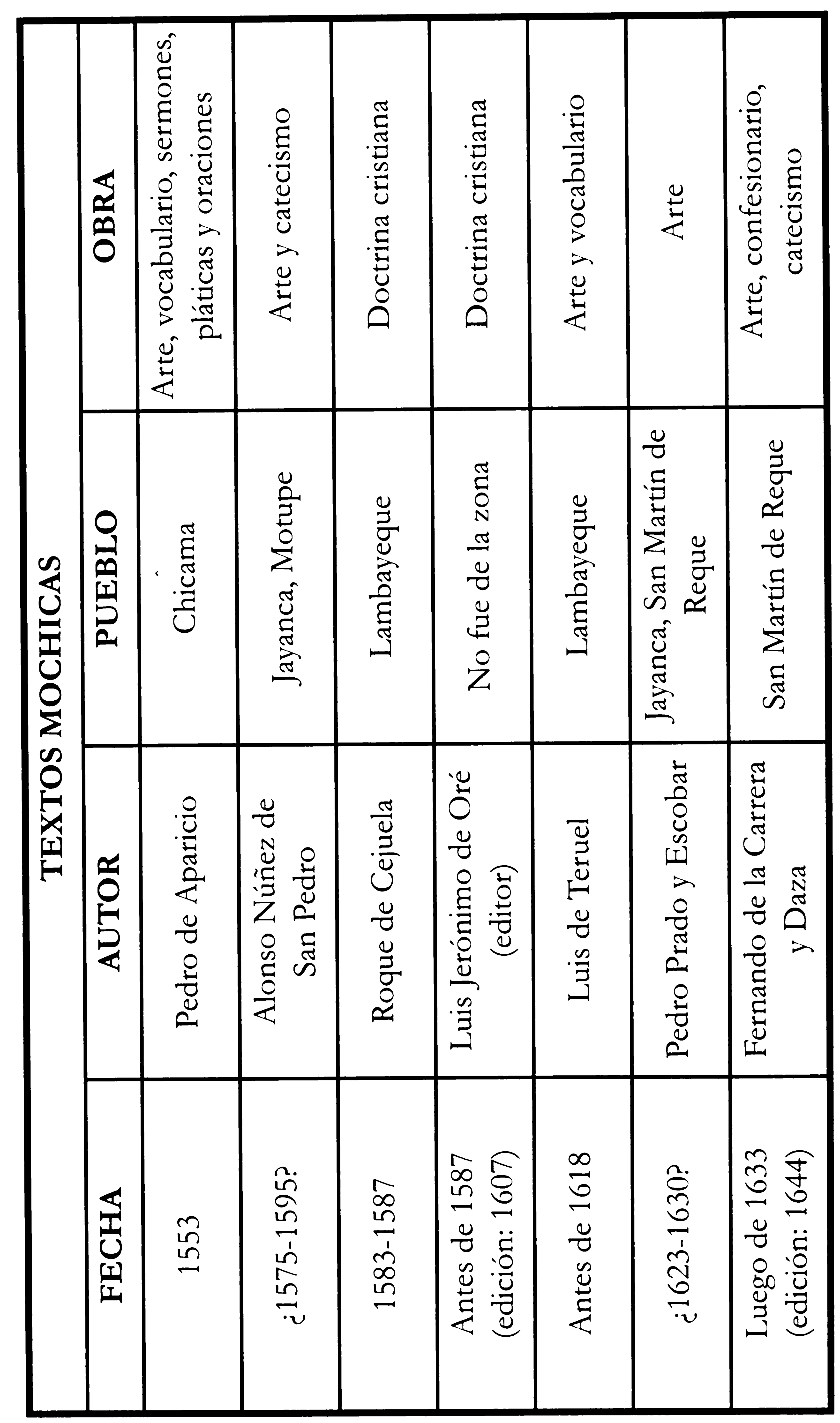


Por el tipo de textos producidos, creemos que los fines que motivaban el aprendizaje de la lengua mochica obedecían a un deseo de efectuar la tarea de catequizar a la población de la costa norte del Perú. Un año antes de su fallecimiento, Jorge Zevallos Quiñones (1996) publicó un erudito artículo acerca de los exámenes que rendían los curas para poder ejercer como sacerdotes en uno de los pueblos de la costa norperuana. Zevallos Quiñones indica la fecha, quién compone el jurado, el nombre del examinado y — cuando existe la información- a qué orden pertenece, qué tipo de examen se le practicó y la opción a la que se presentaba para ejercer su ministerio.

Resulta curioso que algunos sacerdotes fueran examinados en dos ocasiones: Rodrigo Paz Verero, cura de Monsefú, examinado en 1614 fue reexaminado con éxito en 1628 cuando se desempeñaba como cura de Ferreñafe. Lo mismo acontece con el bachiller Gonzalo Jacinto de Miranda, quien fue examinado por vez primera en 1624 al postular de Íllimo para cualquier parroquia, y reexaminado en 1631 para optar por el pueblo de Lambayeque. El listado de Zevallos Quiñones muestra un hecho singular. García de Somorrostro, quien figuraba como examinador en las pruebas del 5 de octubre y del 12 de diciembre de 1621 recién será examinado el 30 de diciembre de dicho año. Otro detalle que se percibe en la lista de Zevallos Quiñones es que los examinados podían ejercer como examinadores. Tal fue el caso de fray Marcos García, que tras ser examinado en 1621 realiza como examinador un examen en 1624. Incluso se podría aplicar este caso al ya mentado García de Somorrostro que, tras ser examinado, continuó como examinador. 
En la relación de examinados, aparecen tres nombres importantes para la lengua mochica. El principal de ellos - ¿qué duda cabe? - es Fernando de la Carrera, autor del Arte de la lengua yunga. Los otros dos son los antes mencionados fray Marcos García, de la orden de San Agustín, y el bachiller Gonzalo Jacinto de Miranda.

Fray Marcos García, cura de Mocupe hacia 1643, se encargó de la censura del Arte de la lengua yunga, frente al cual manifestó su aquiescencia. Gonzalo Jacinto de Miranda, por su parte, es importante para el mochica porque dio su aprobación para la impresión del Arte de la lengua yunga en tanto se desempeñaba como cura de Lambayeque y comisario del Santo Oficio de la jurisdicción de Zaña. A continuación transcribimos la tabla elaborada por Zevallos Quiñones (1996: 15-17), con el añadido del primer examen de 1614 que no figura en la tabla original y la ordenación cronológica estricta de los exámenes. 


\begin{tabular}{|c|c|c|c|c|c|}
\hline $\begin{array}{l}Z \\
0 \\
0 \\
0 \\
0\end{array}$ & 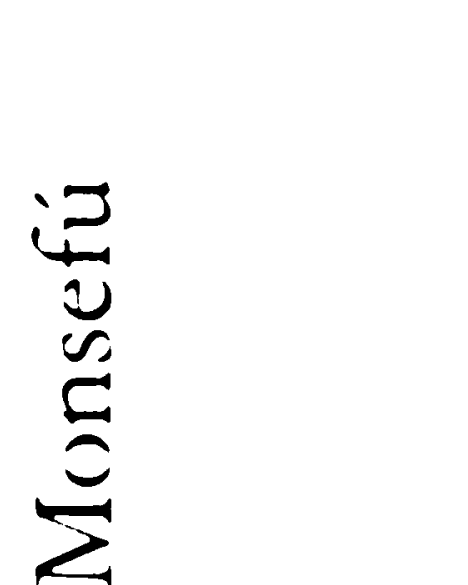 & 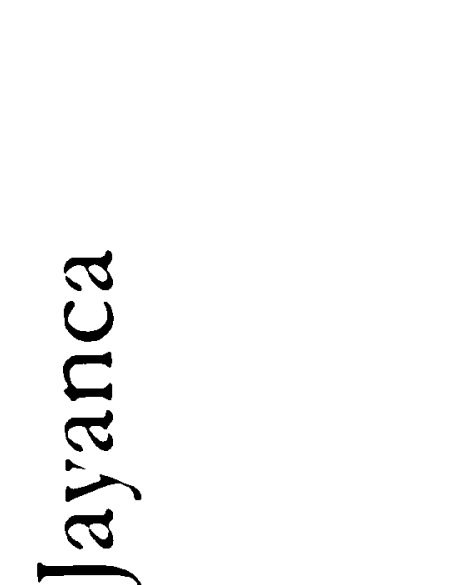 & & 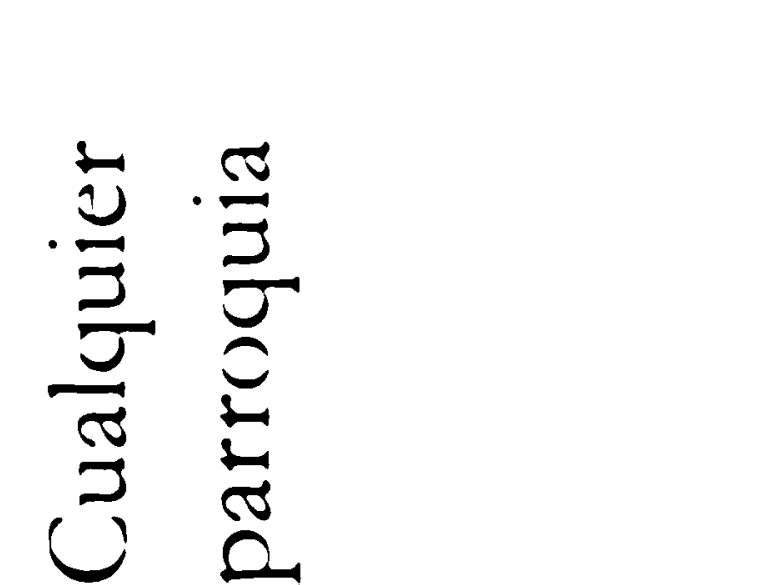 & 芯 \\
\hline 䆓恋 & 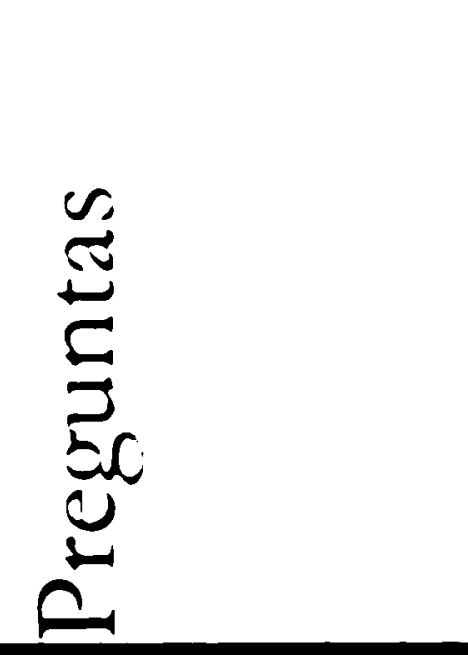 & & & & \\
\hline 孞 & . & 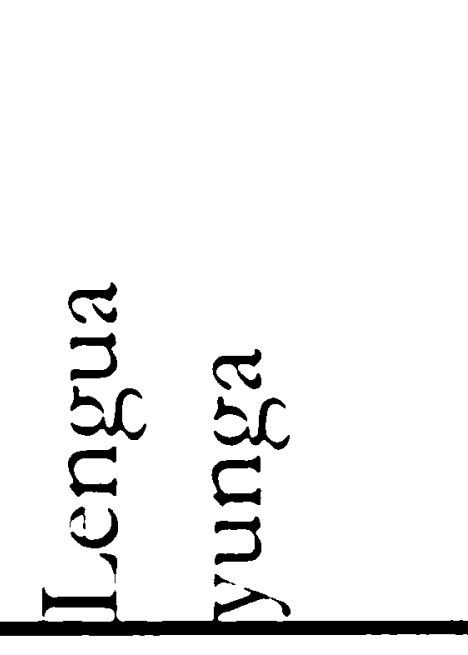 & 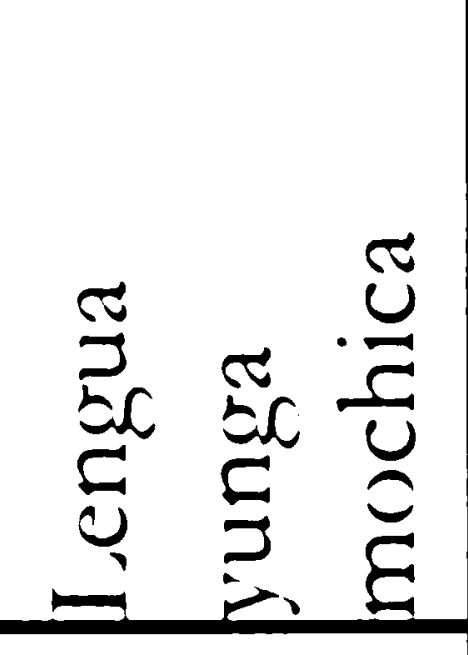 & 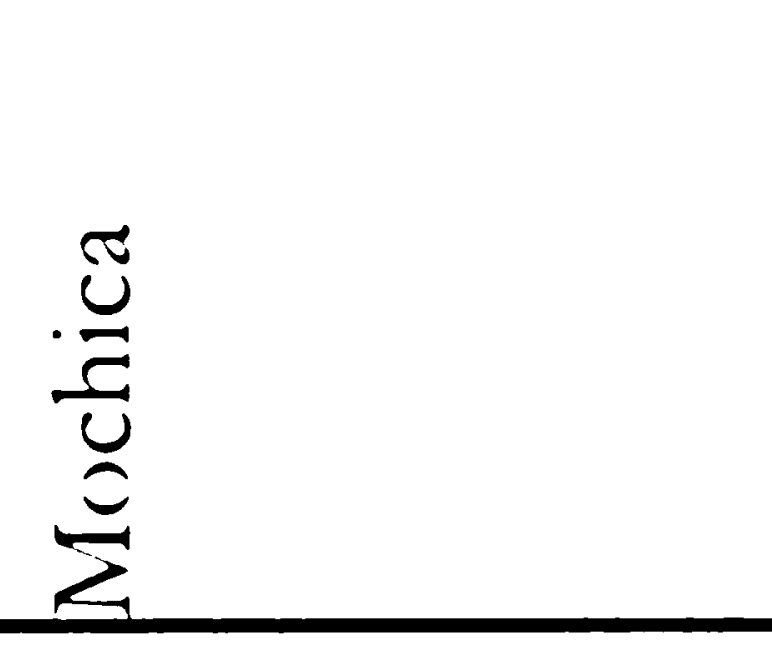 & 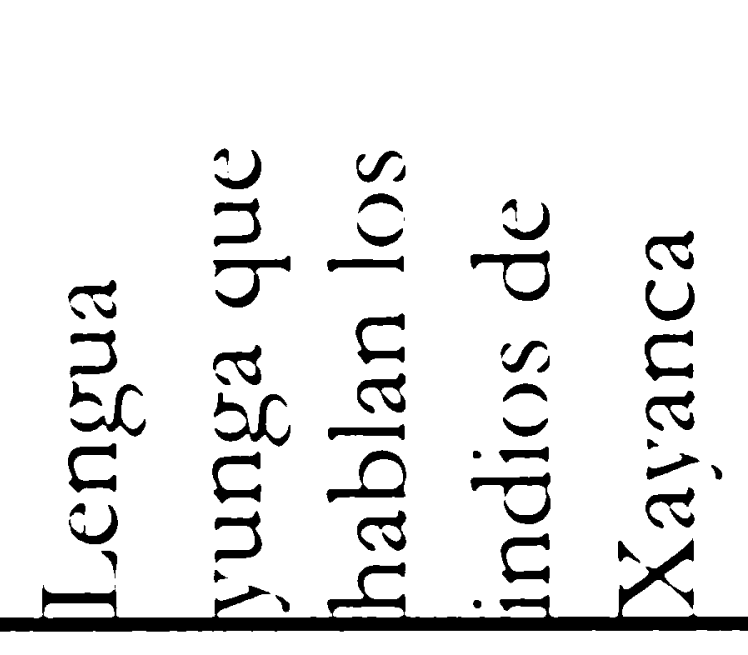 \\
\hline 肙 & 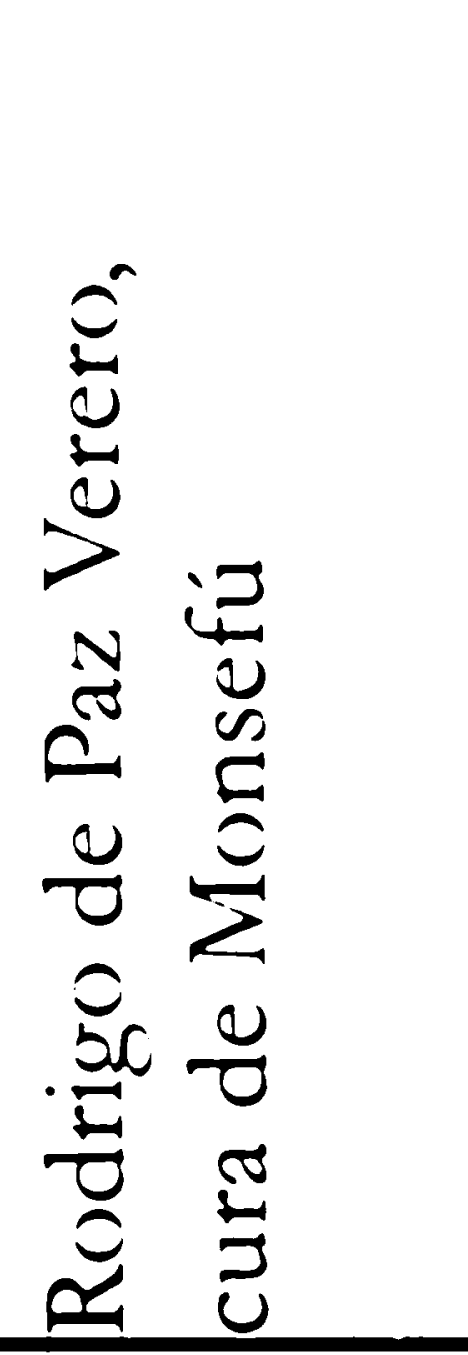 & 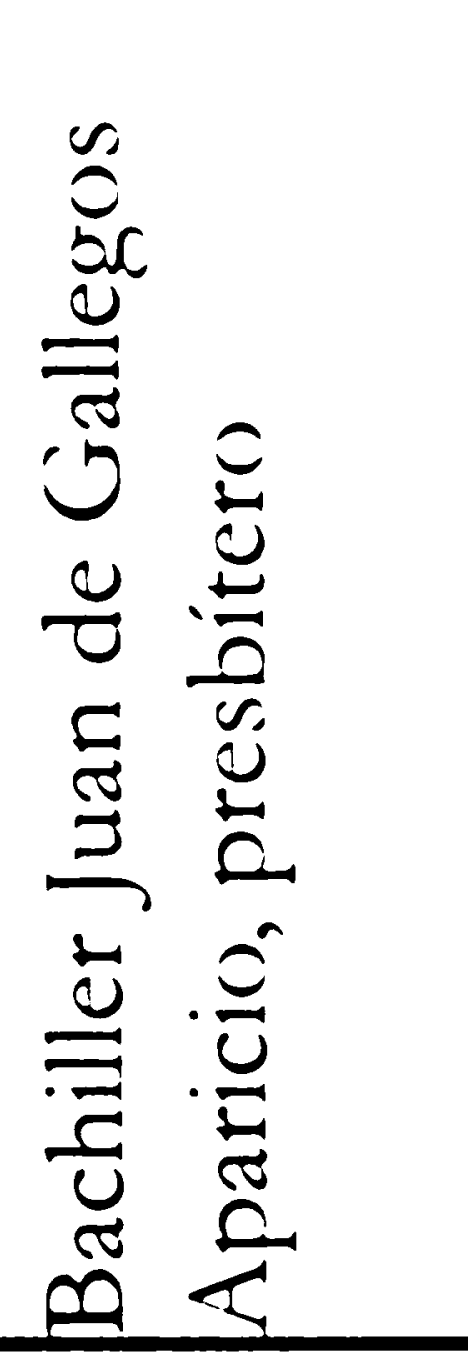 & 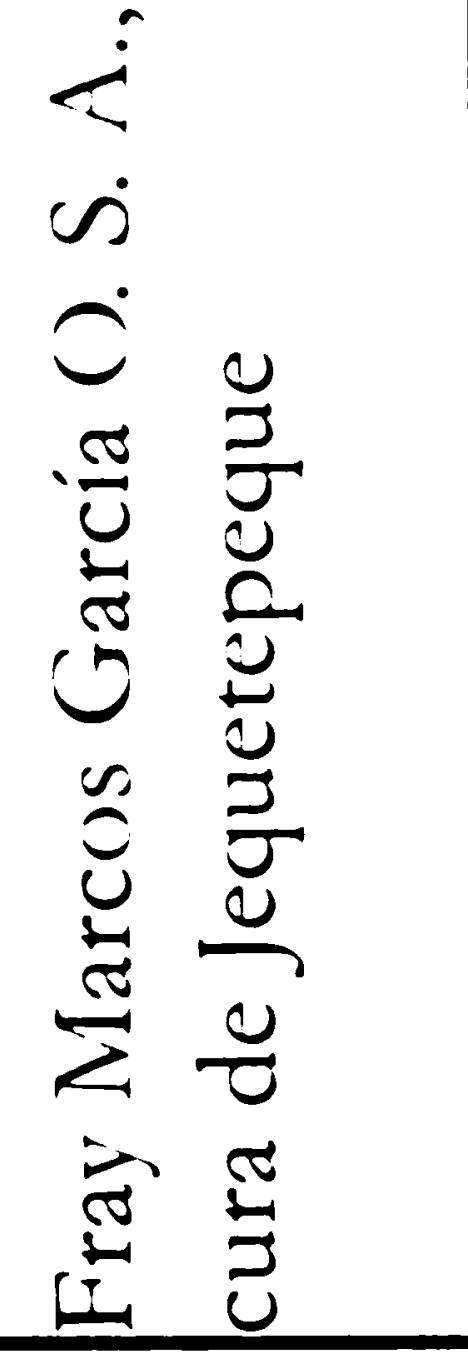 & 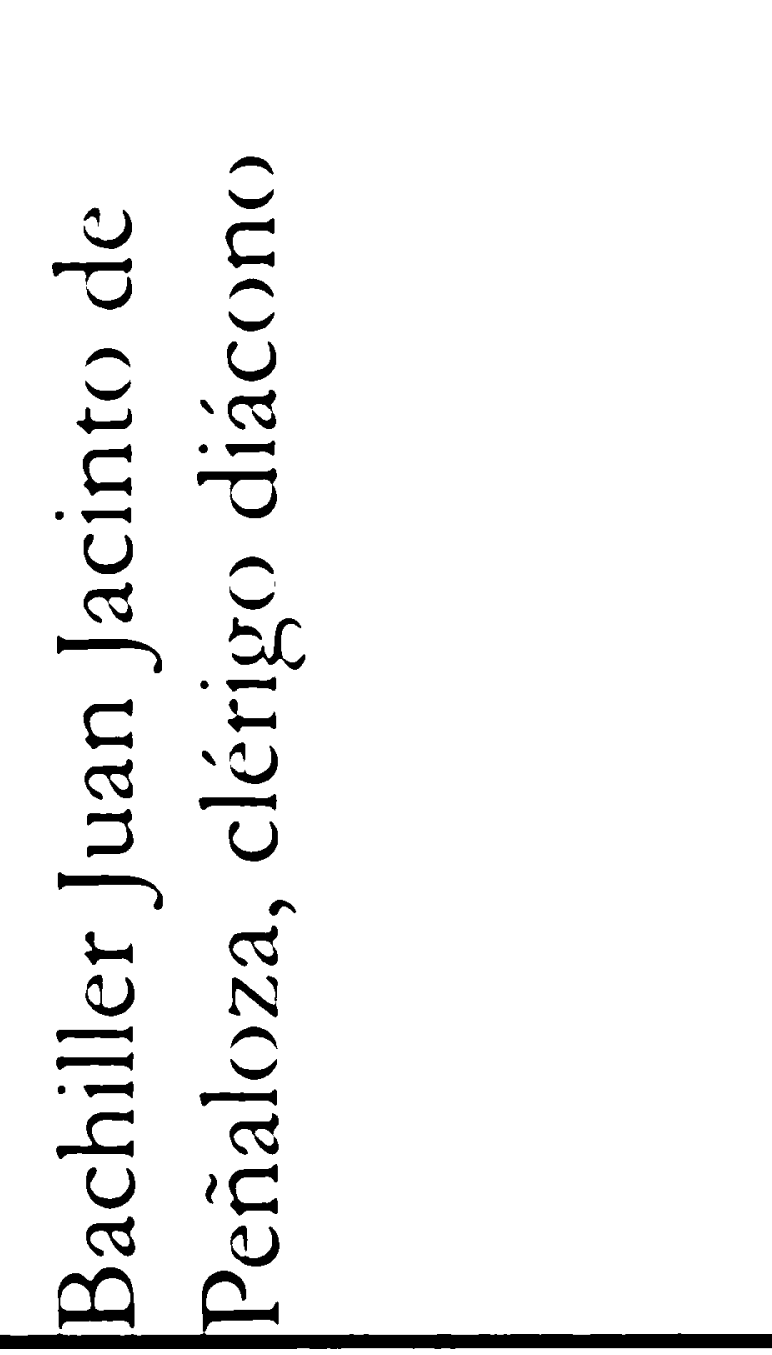 & 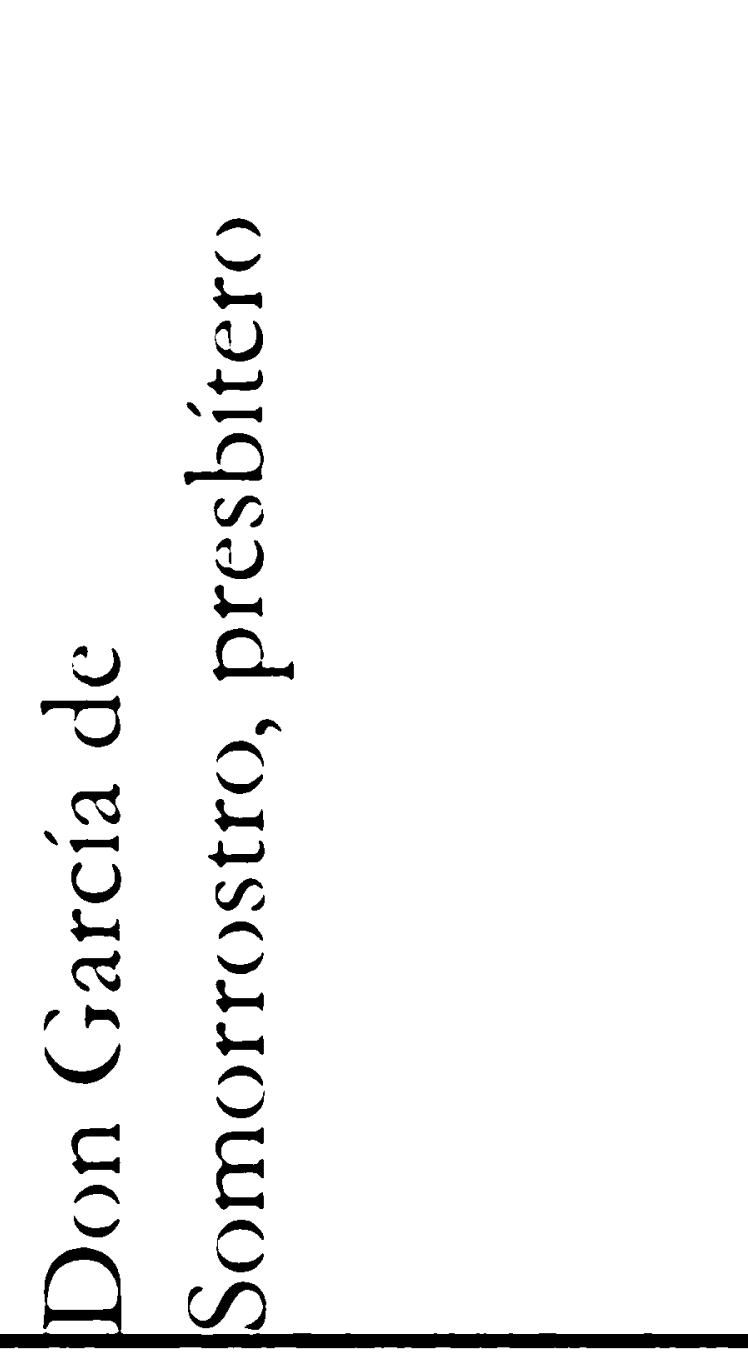 \\
\hline 号 & 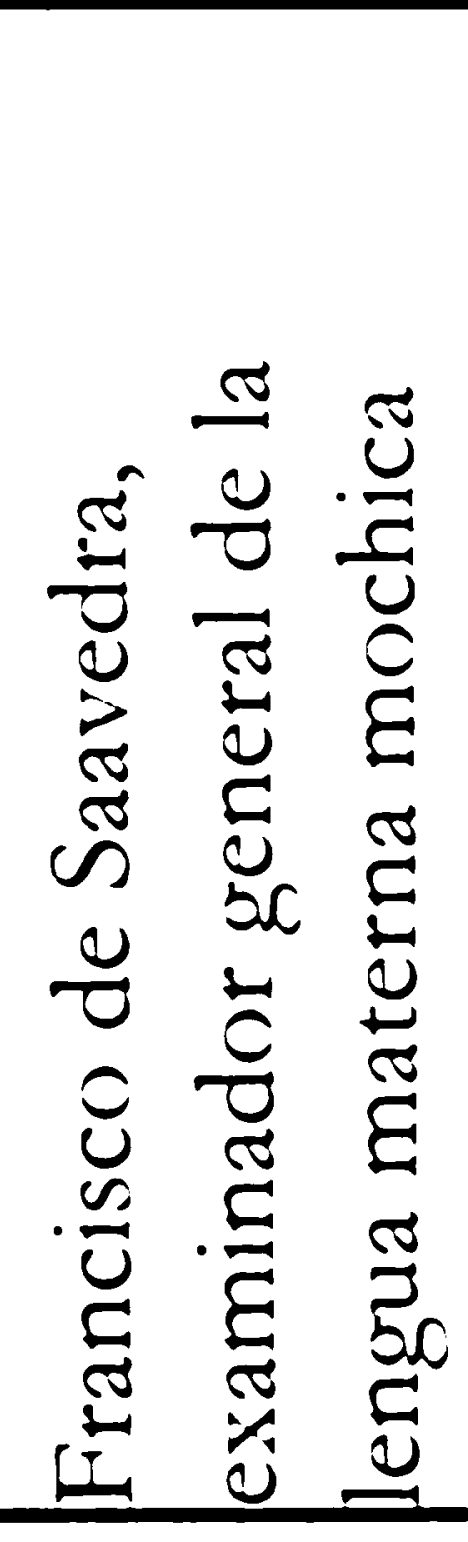 & 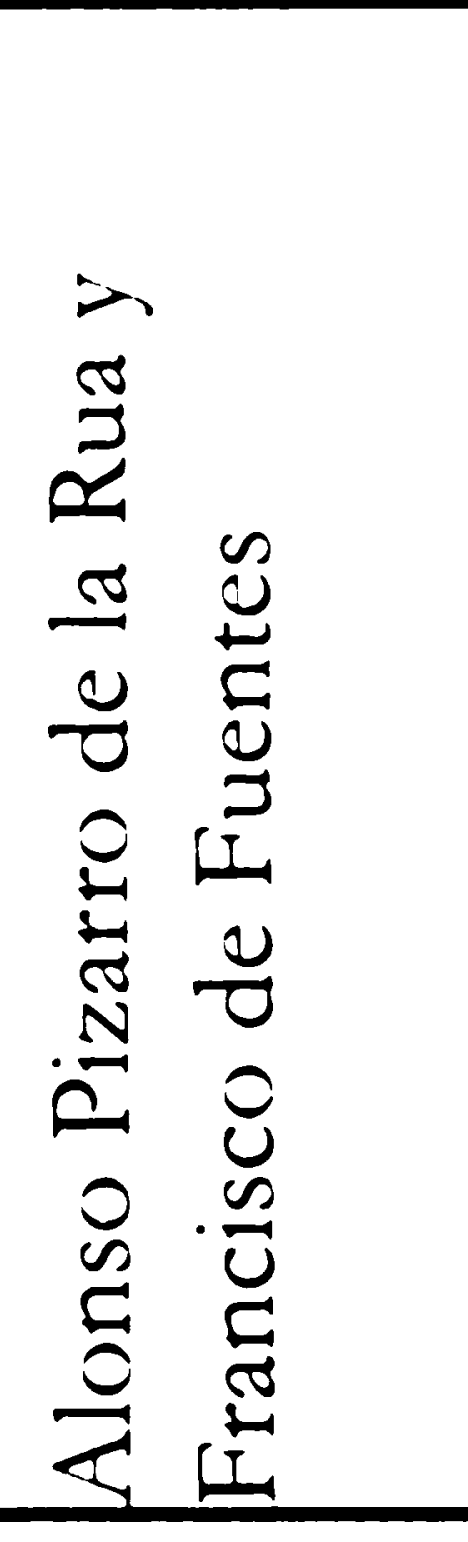 & 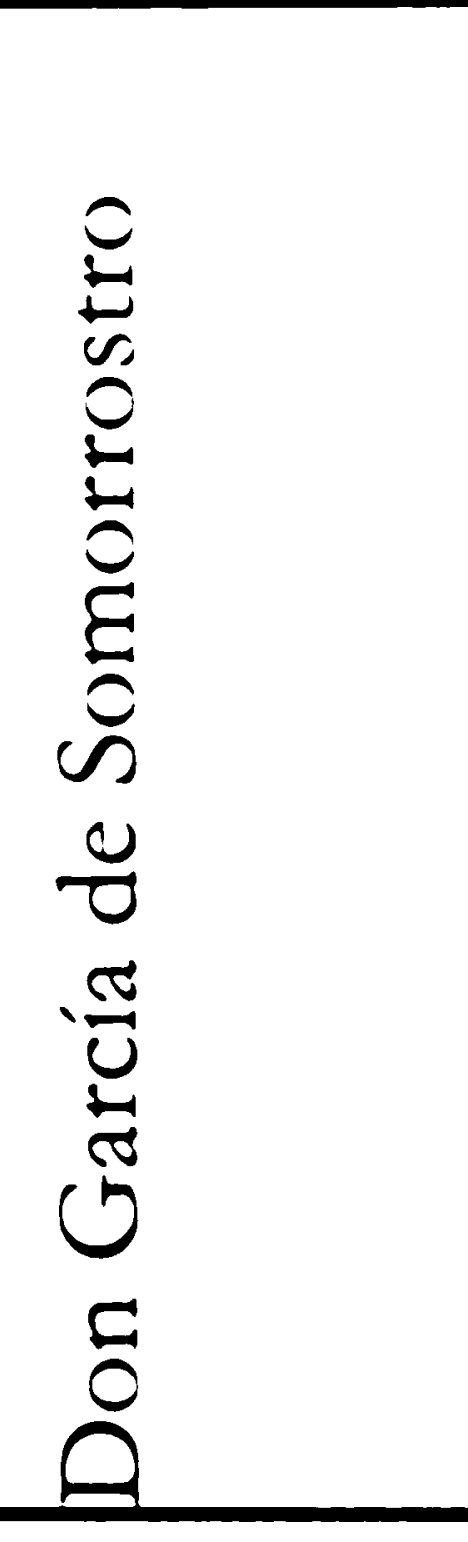 & 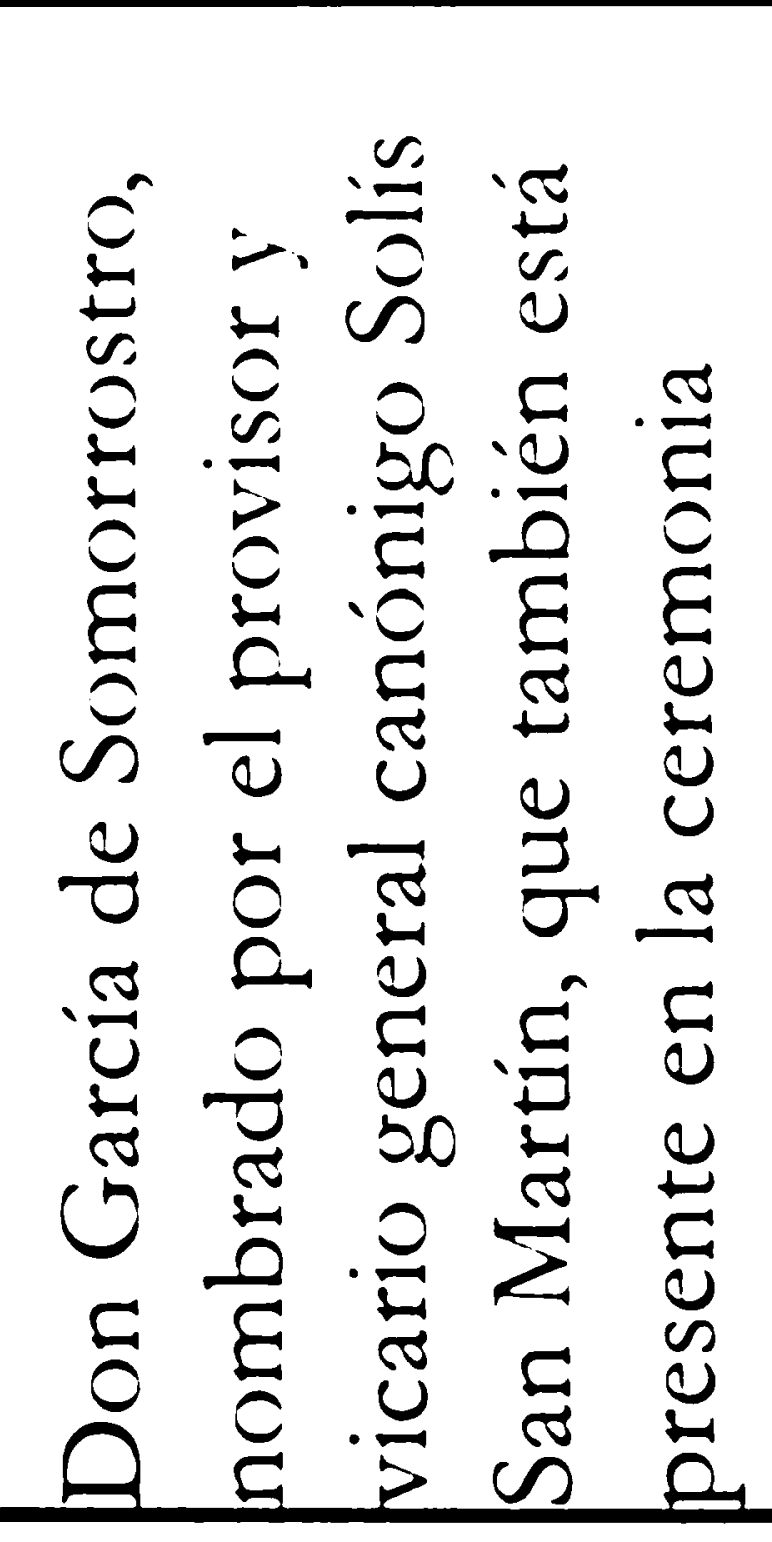 & 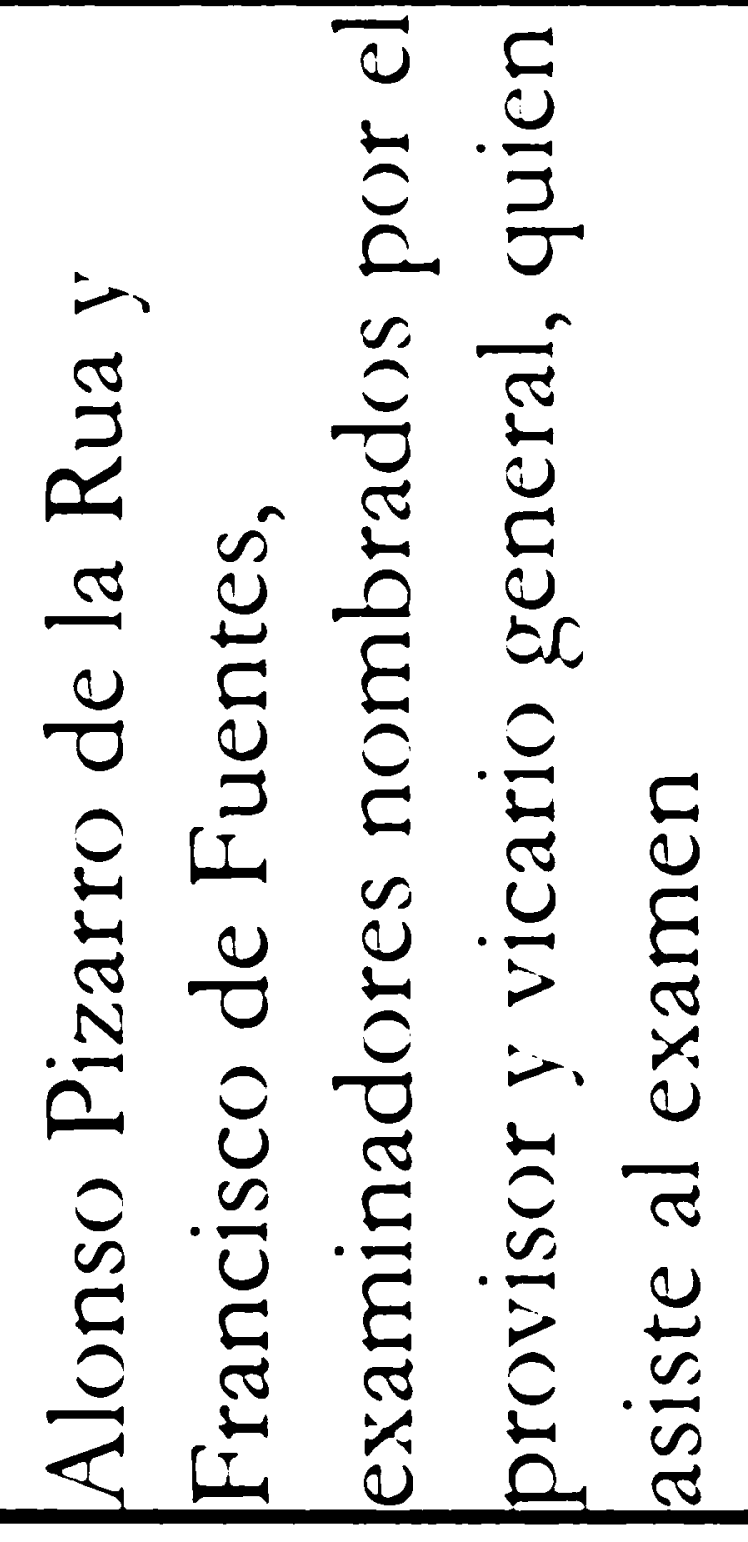 \\
\hline 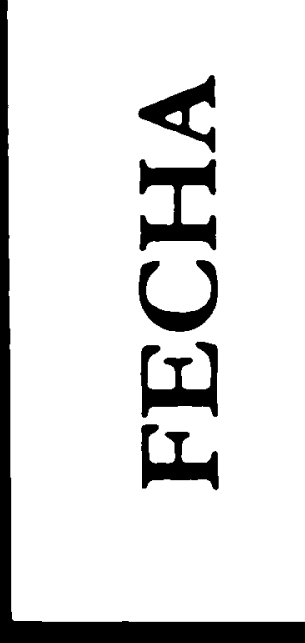 & 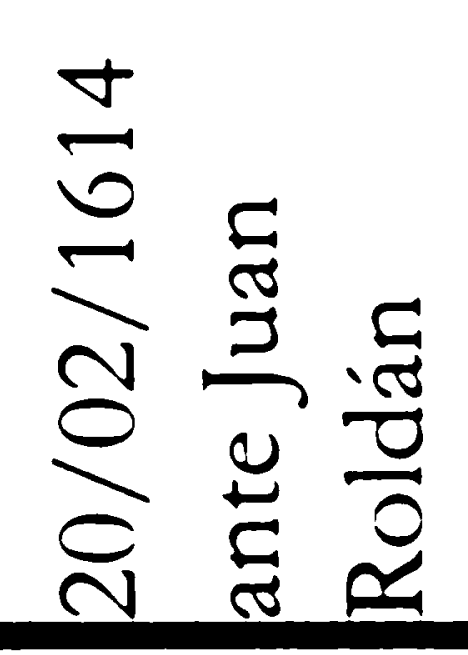 & 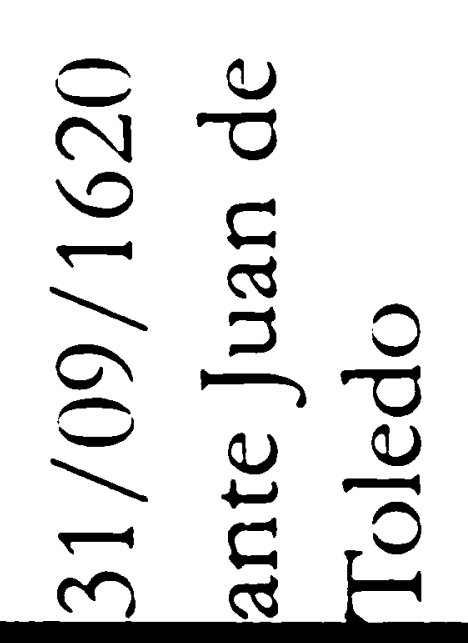 & 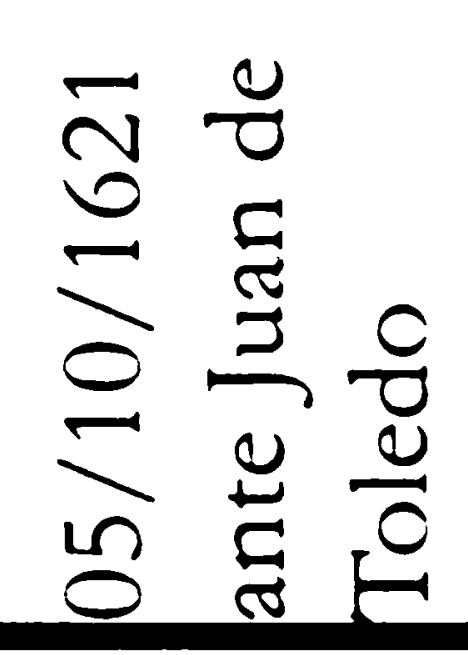 & 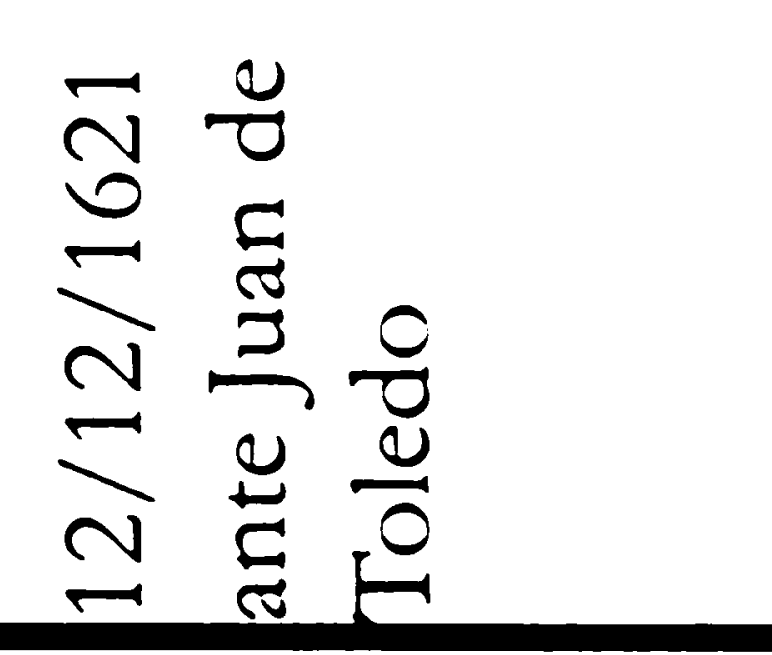 & 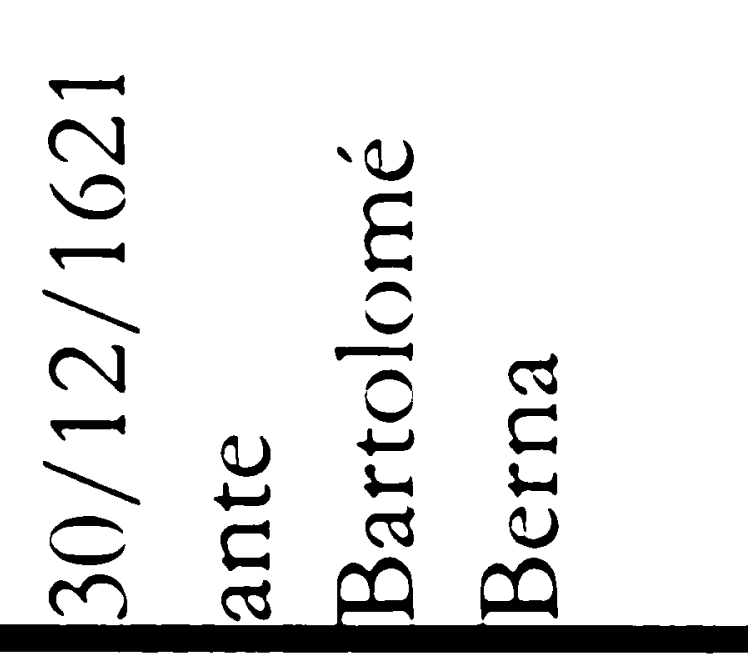 \\
\hline
\end{tabular}




\begin{tabular}{|c|c|c|c|c|}
\hline $\begin{array}{l}Z \\
0 \\
0 \\
0 \\
0 \\
0\end{array}$ & 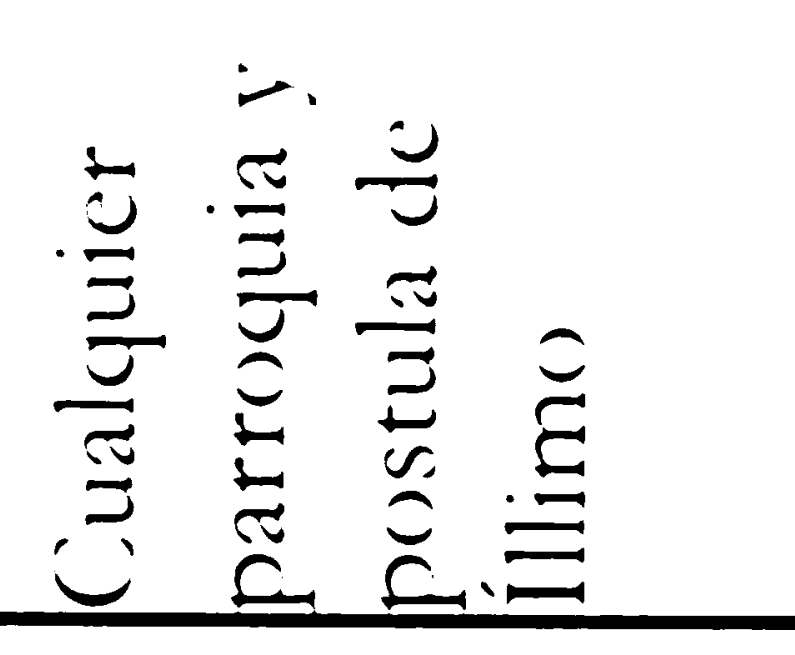 & 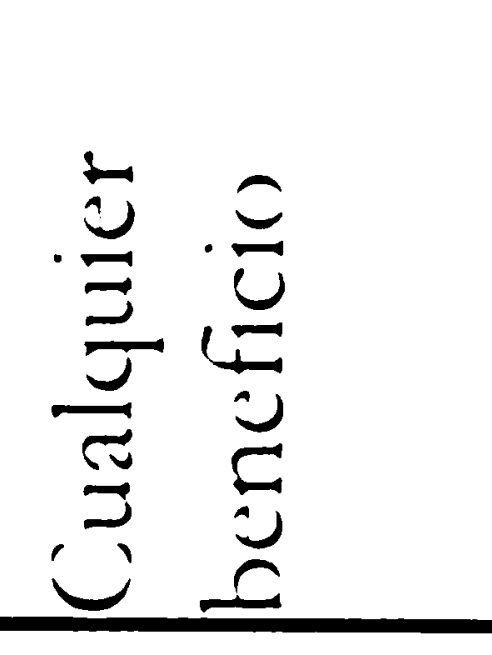 & 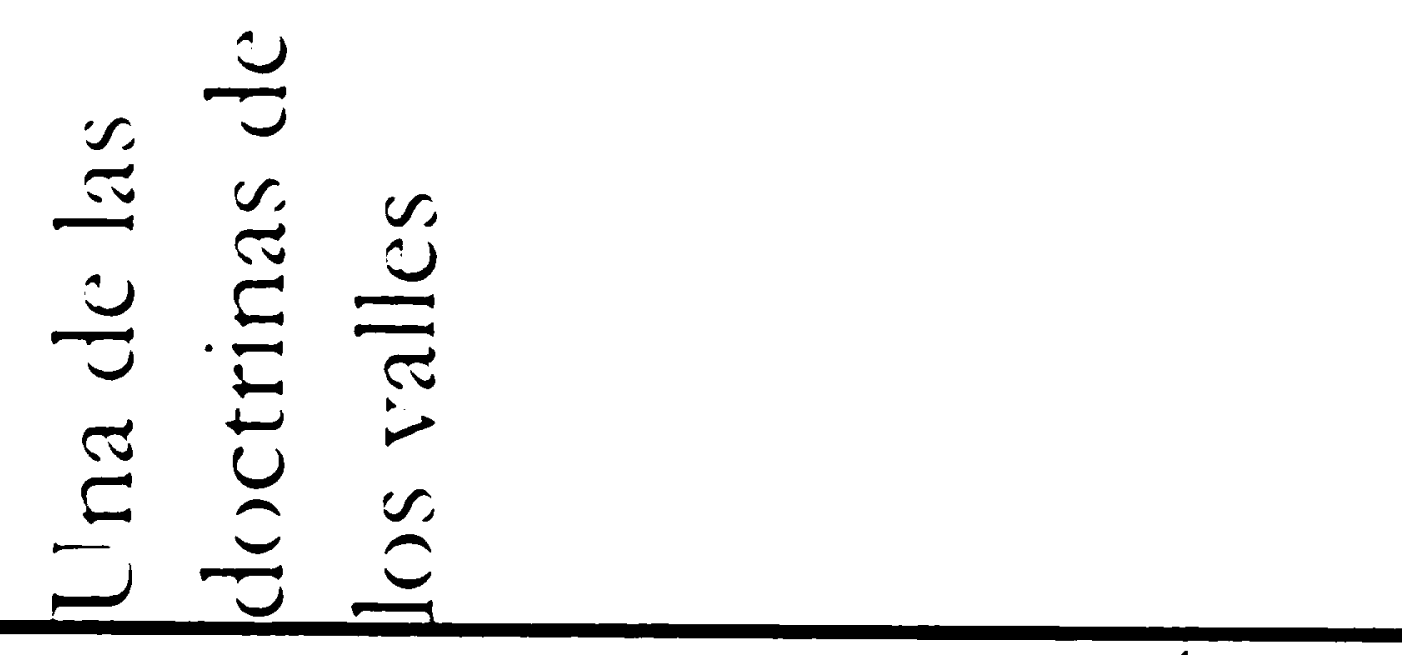 & \\
\hline 恖 & 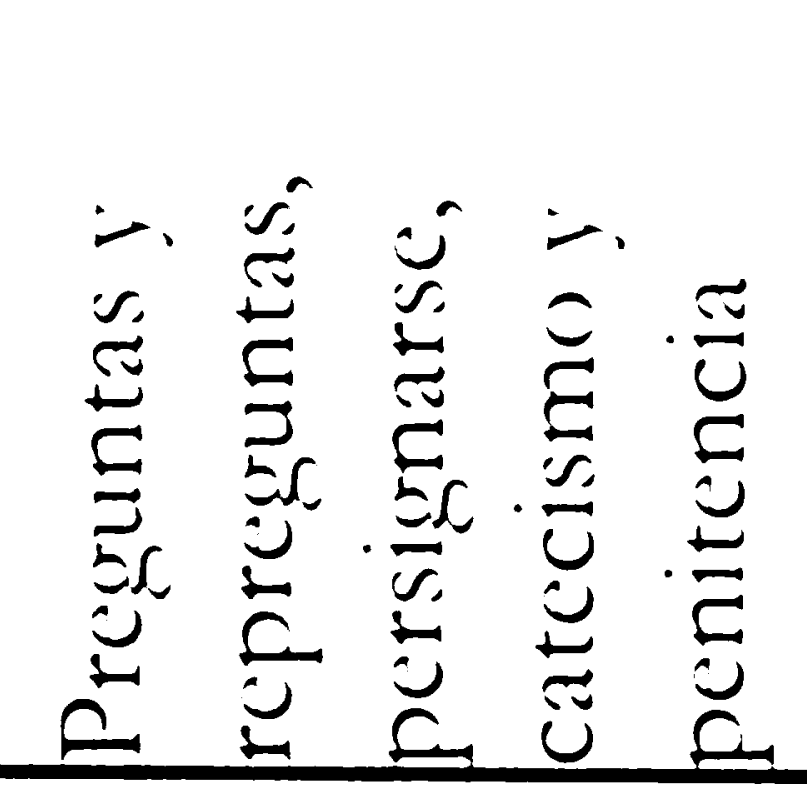 & 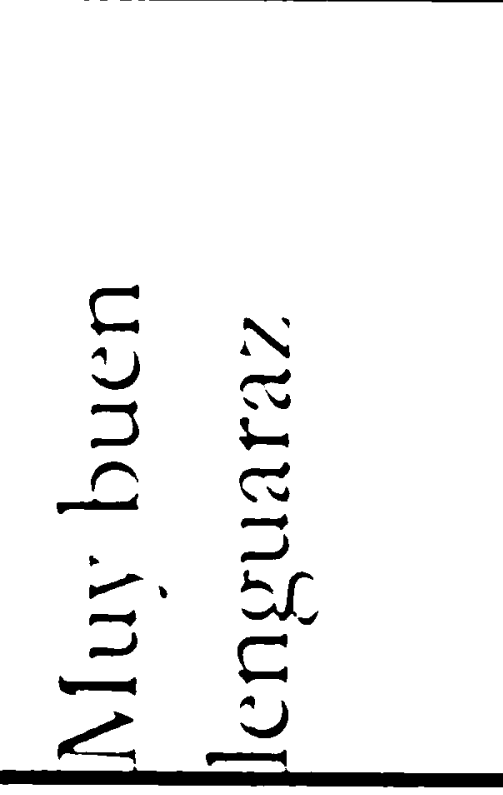 & 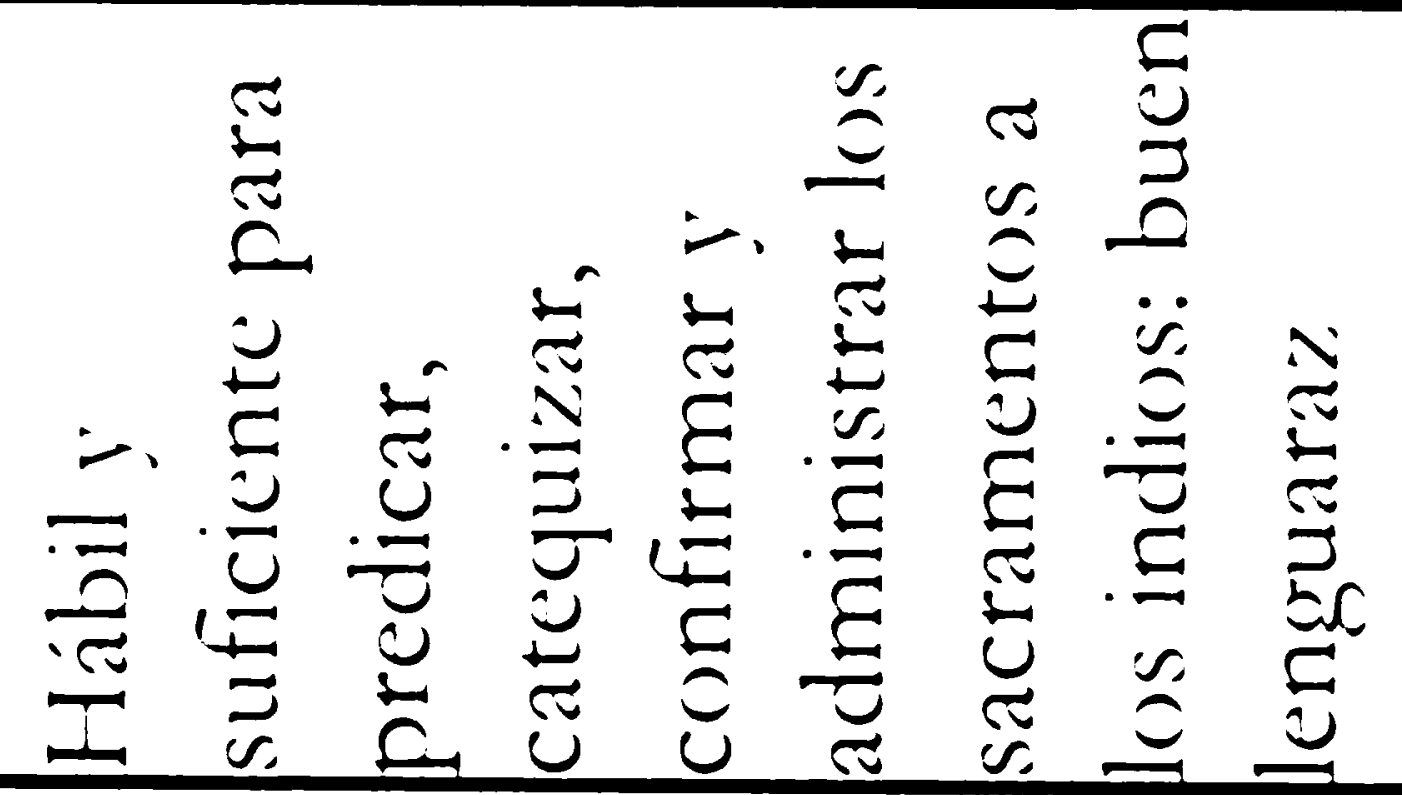 & 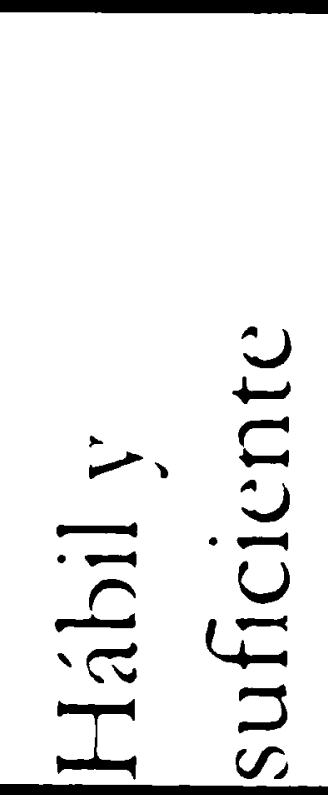 \\
\hline 㥑 & 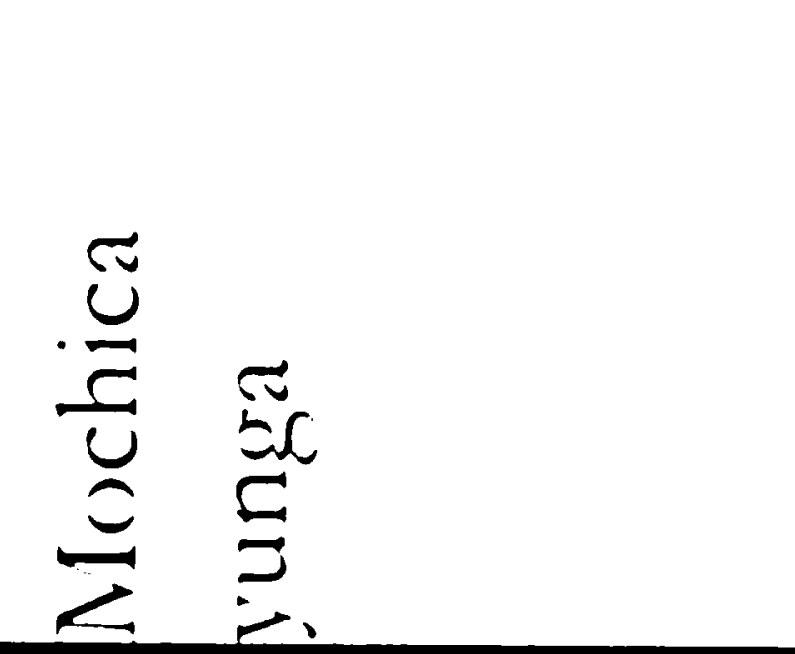 & 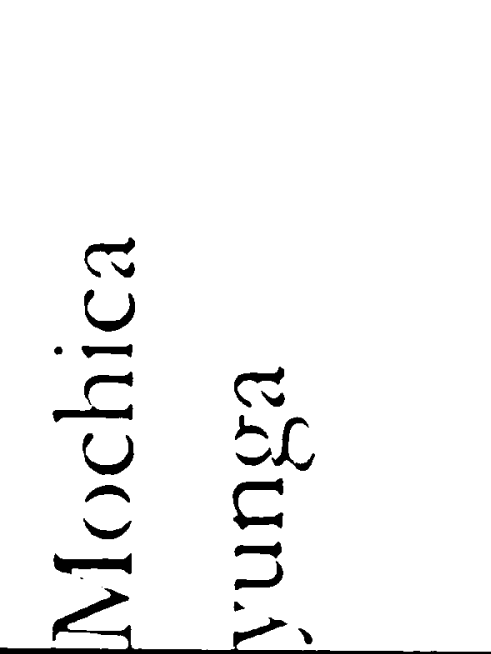 & 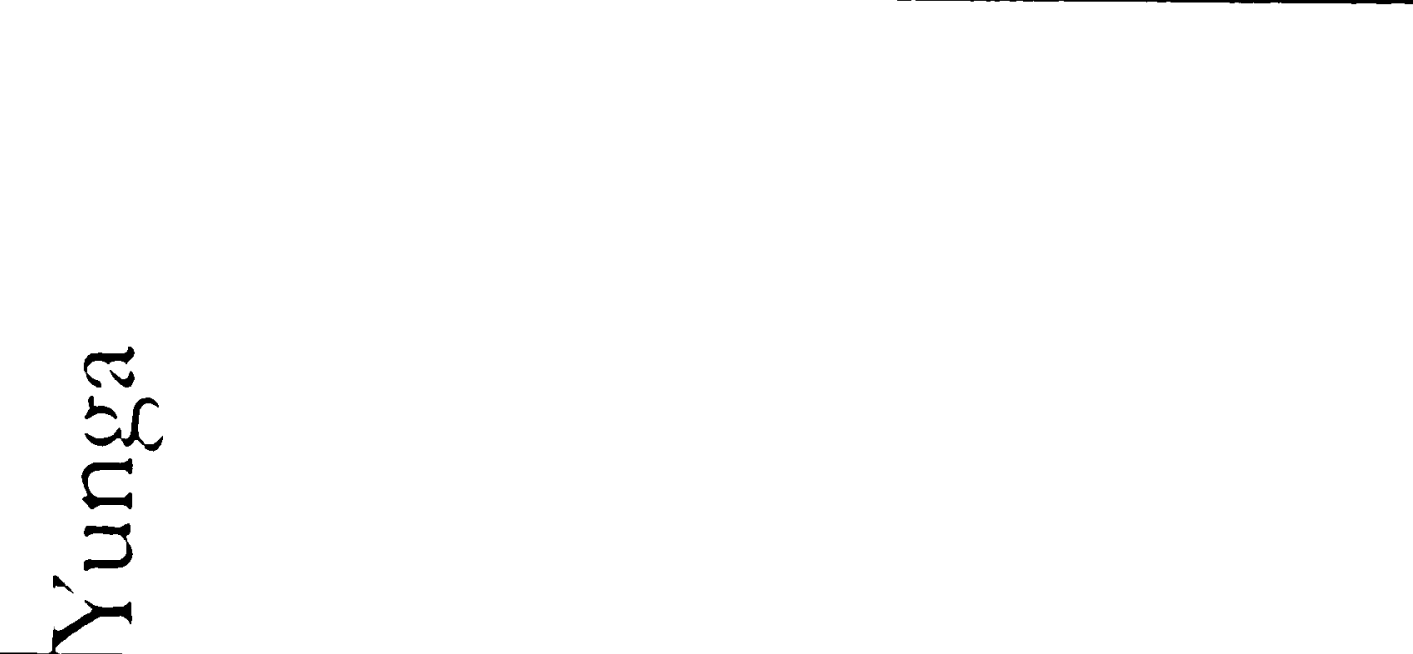 & 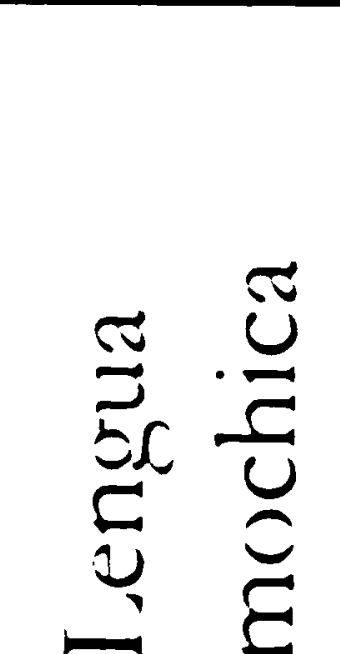 \\
\hline 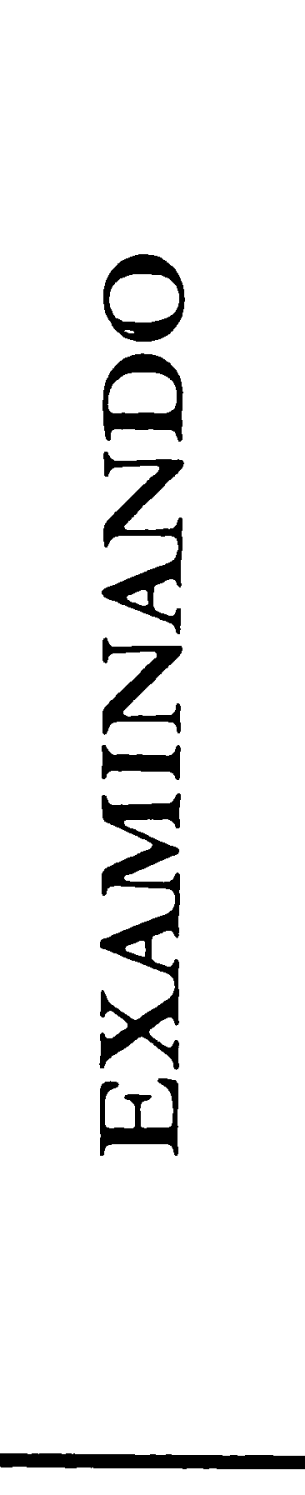 & 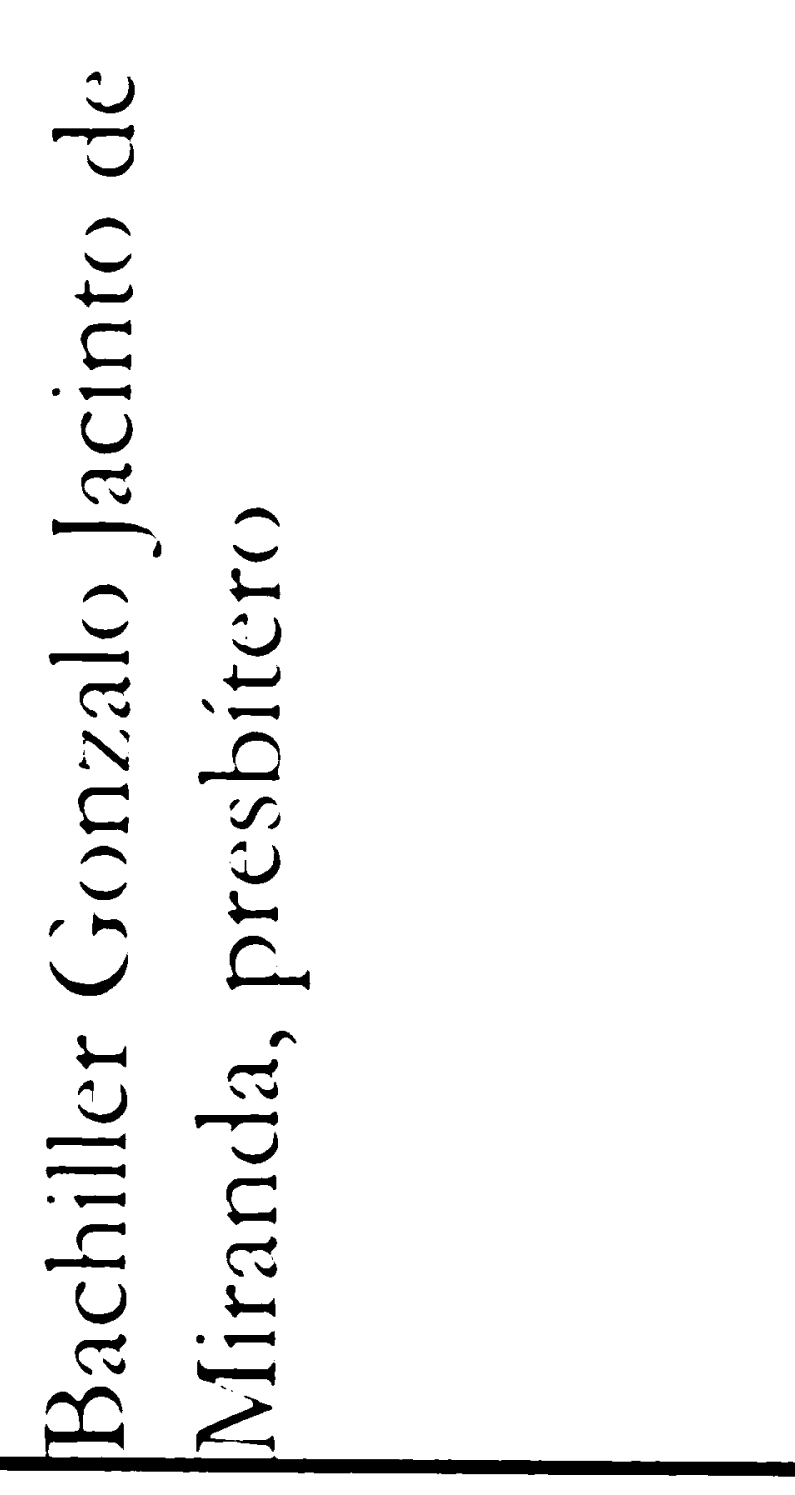 & 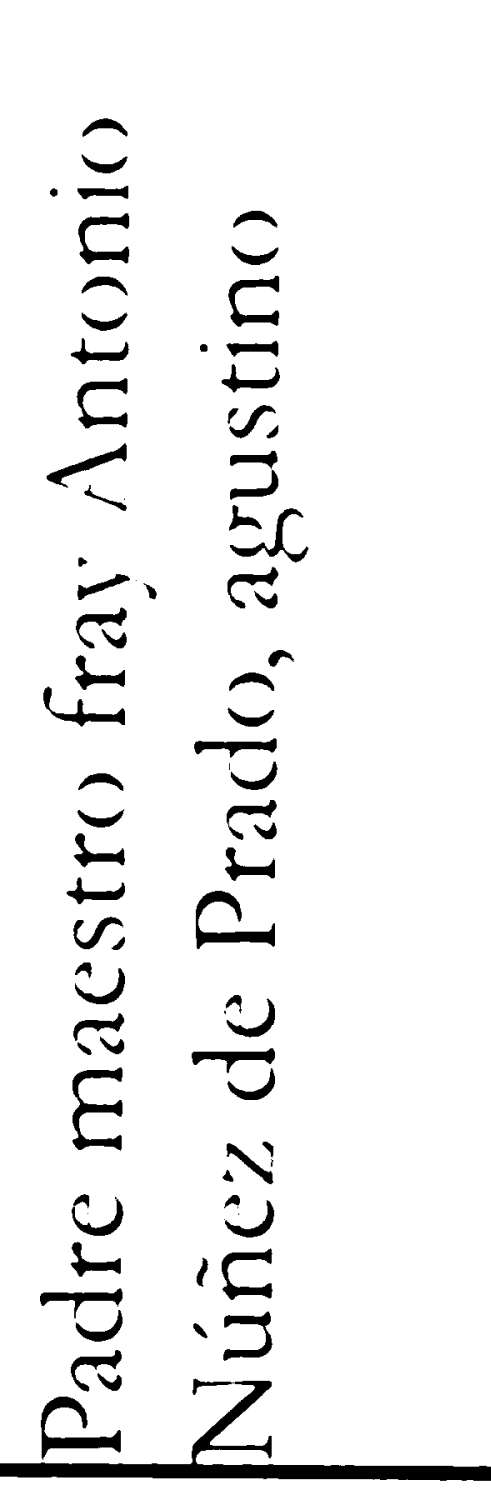 & 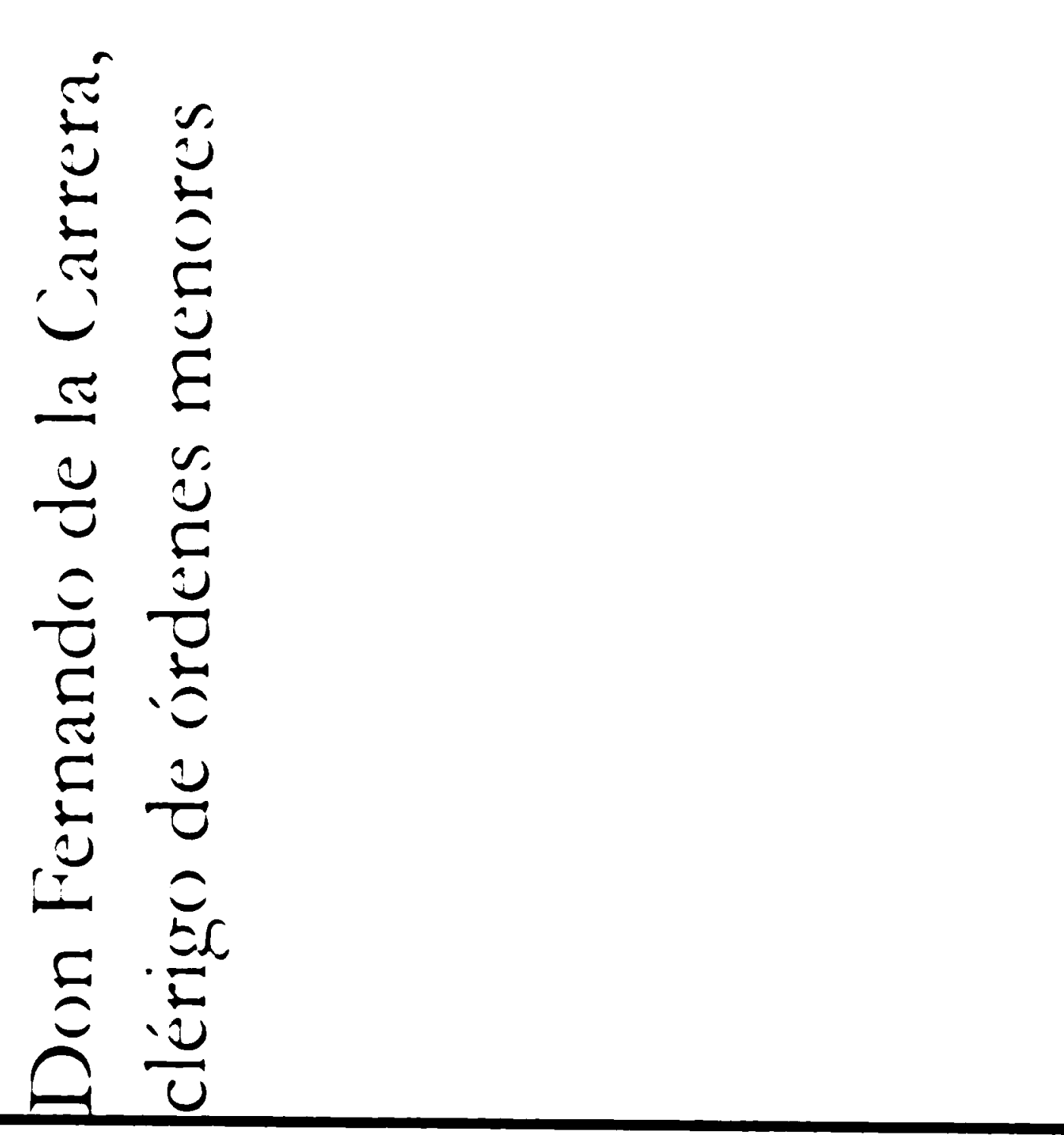 & 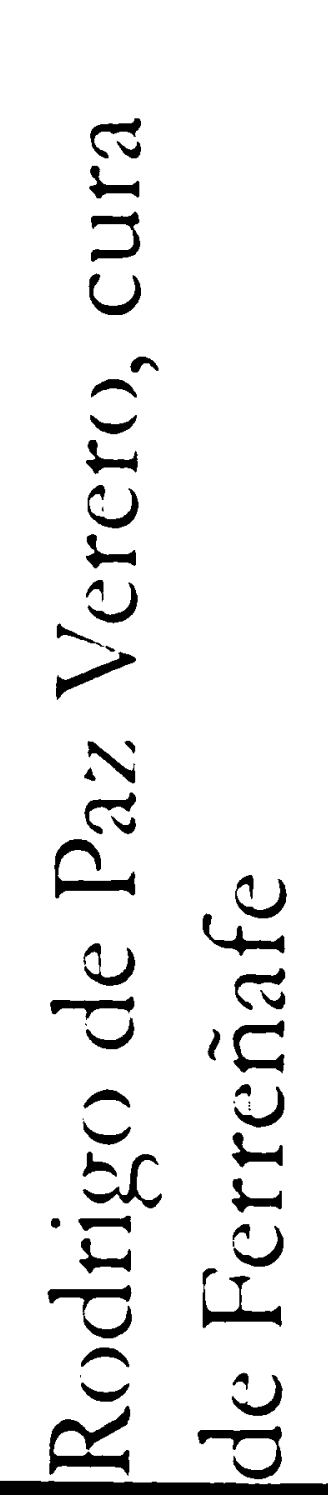 \\
\hline 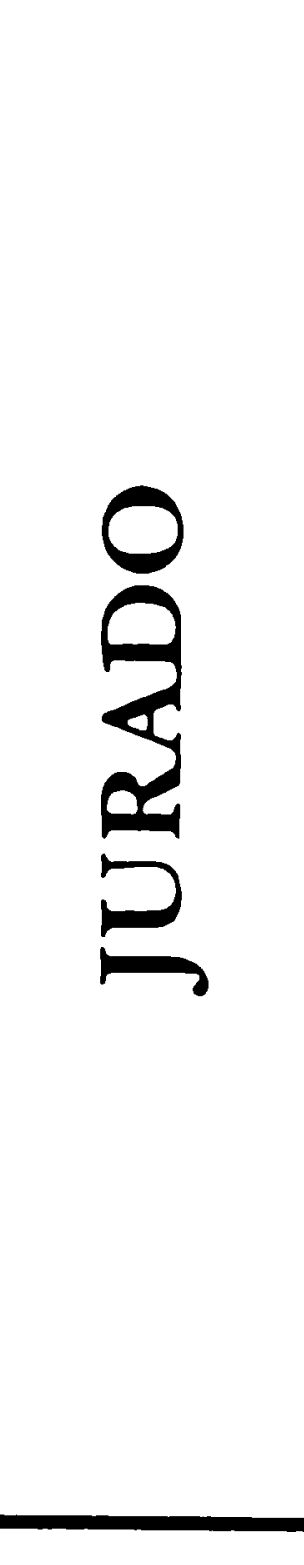 & 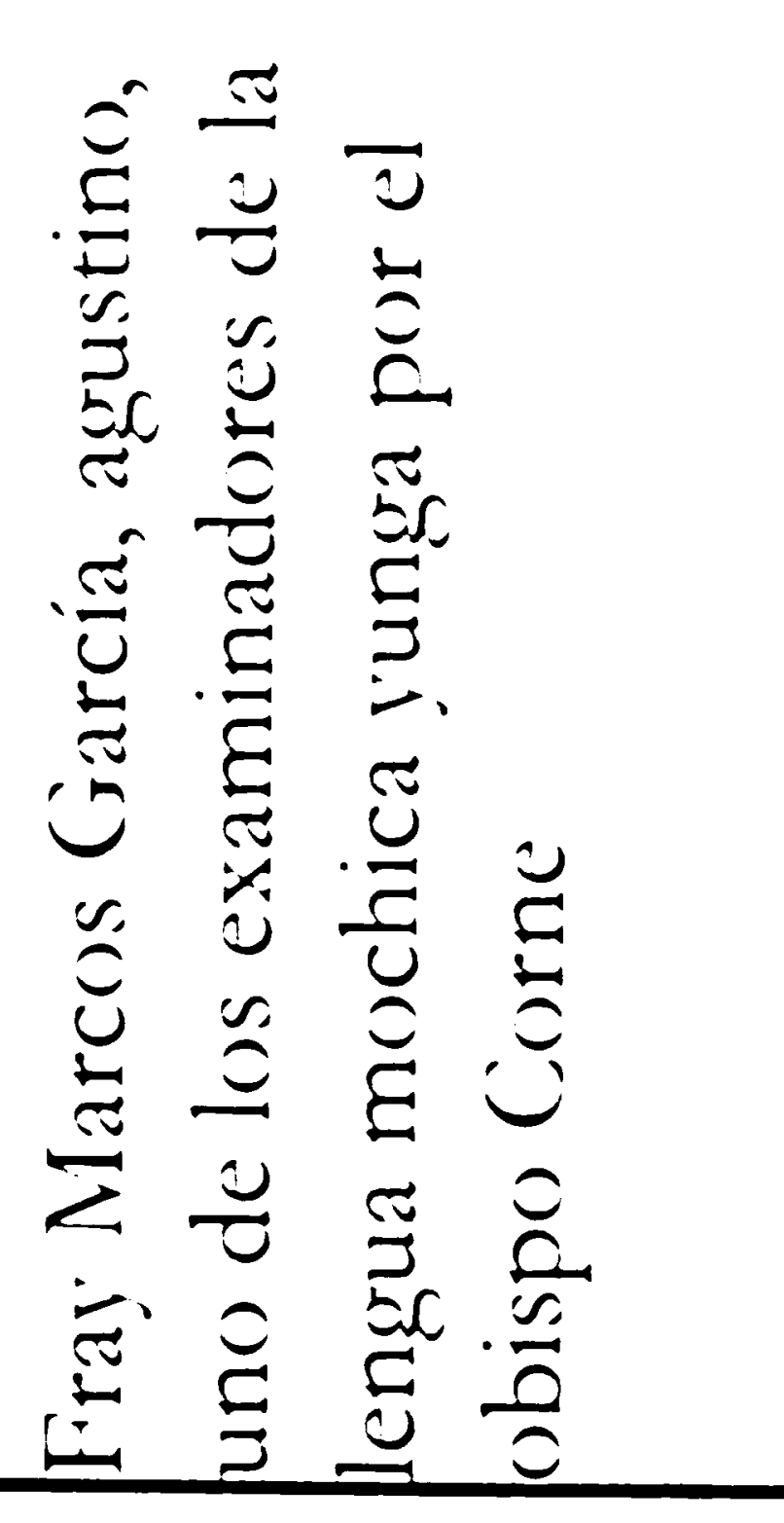 & 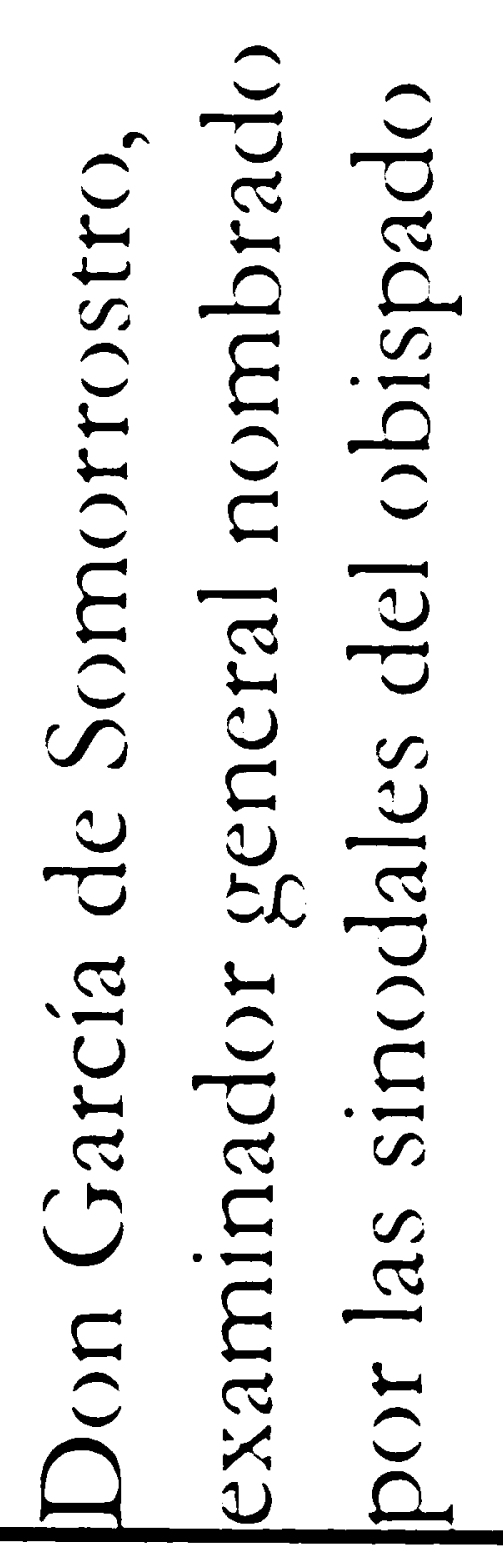 & 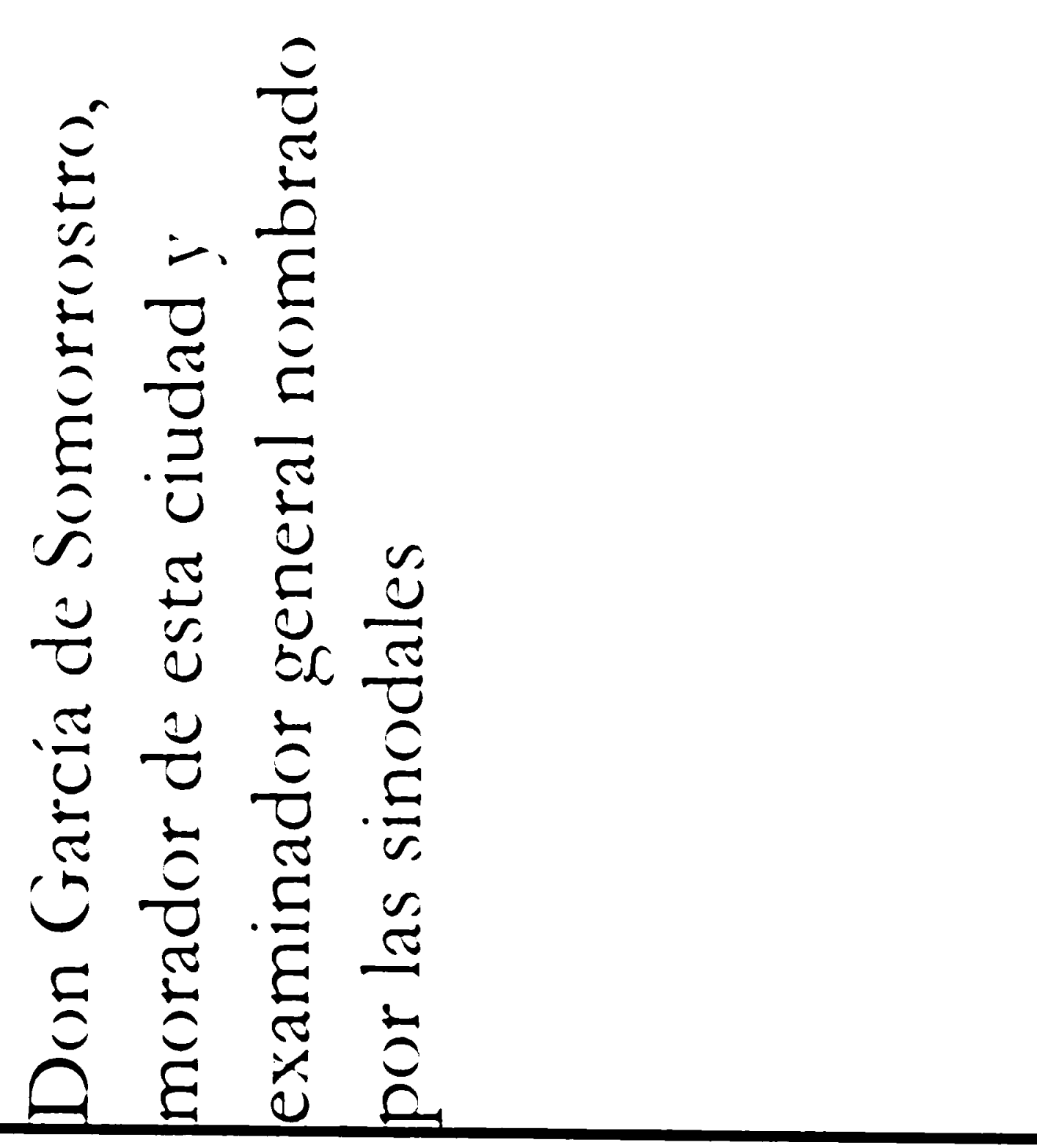 & 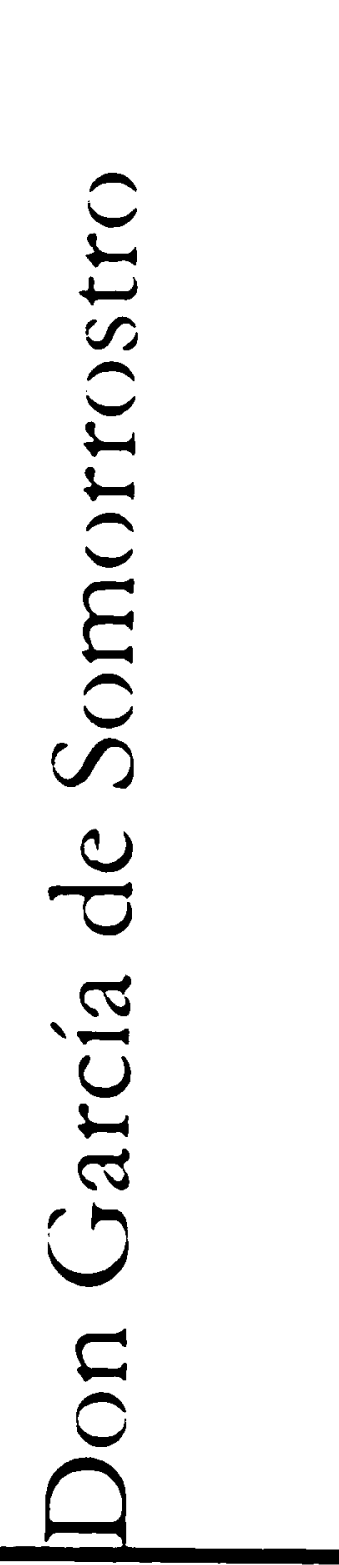 \\
\hline 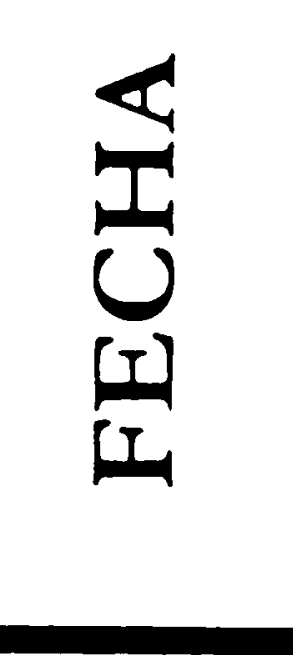 & 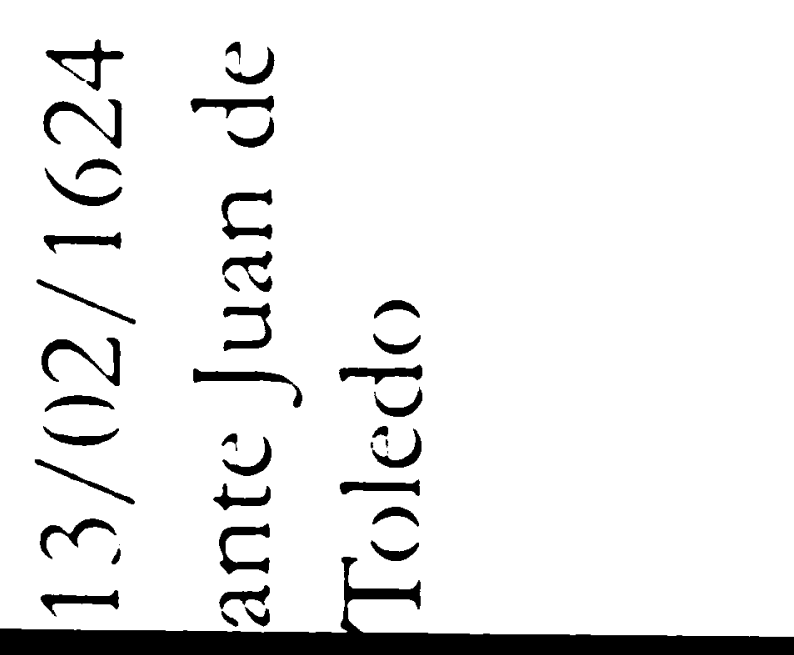 & 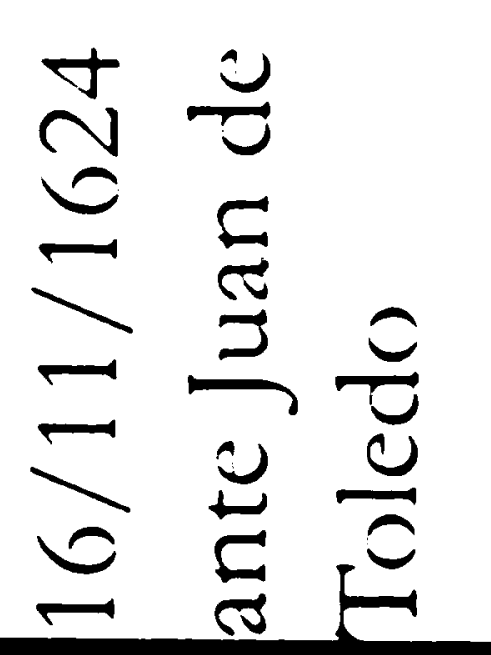 & 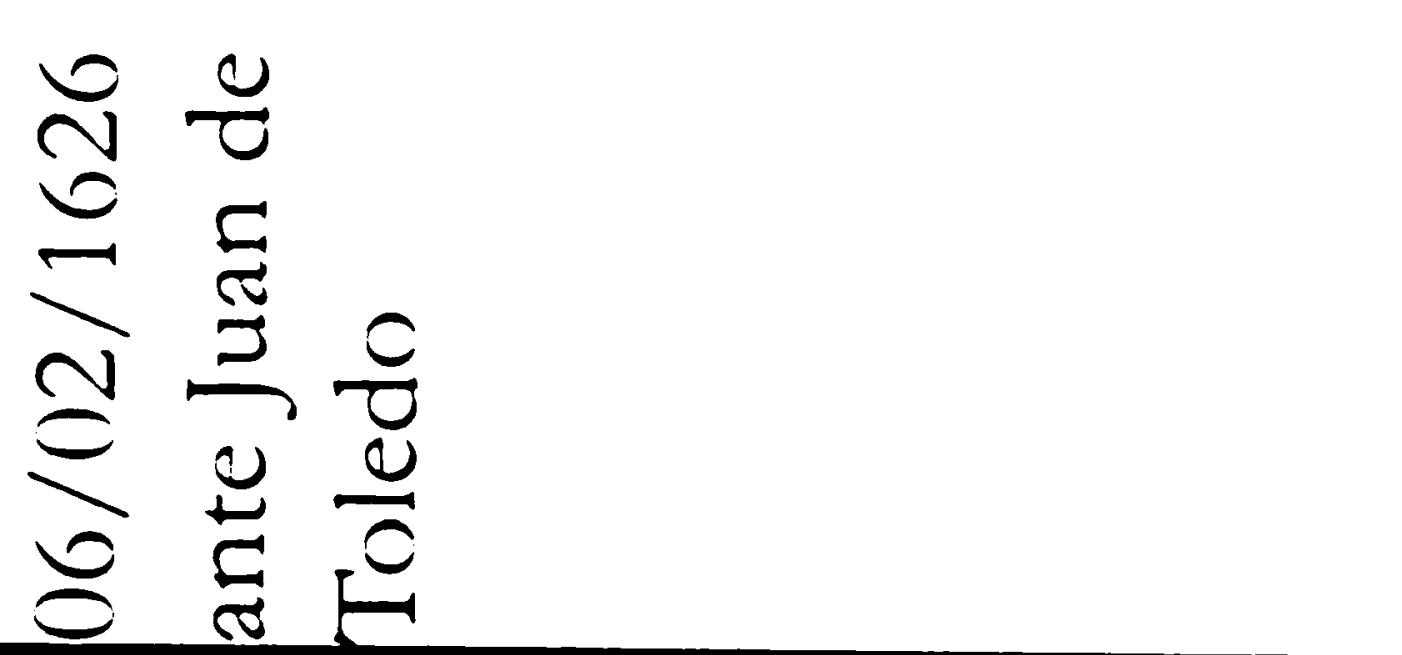 & 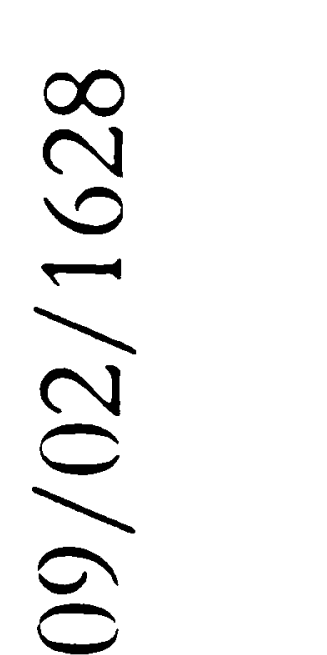 \\
\hline
\end{tabular}




\begin{tabular}{|c|c|c|c|c|}
\hline $\begin{array}{l}Z \\
0 \\
0 \\
0 \\
0\end{array}$ & & 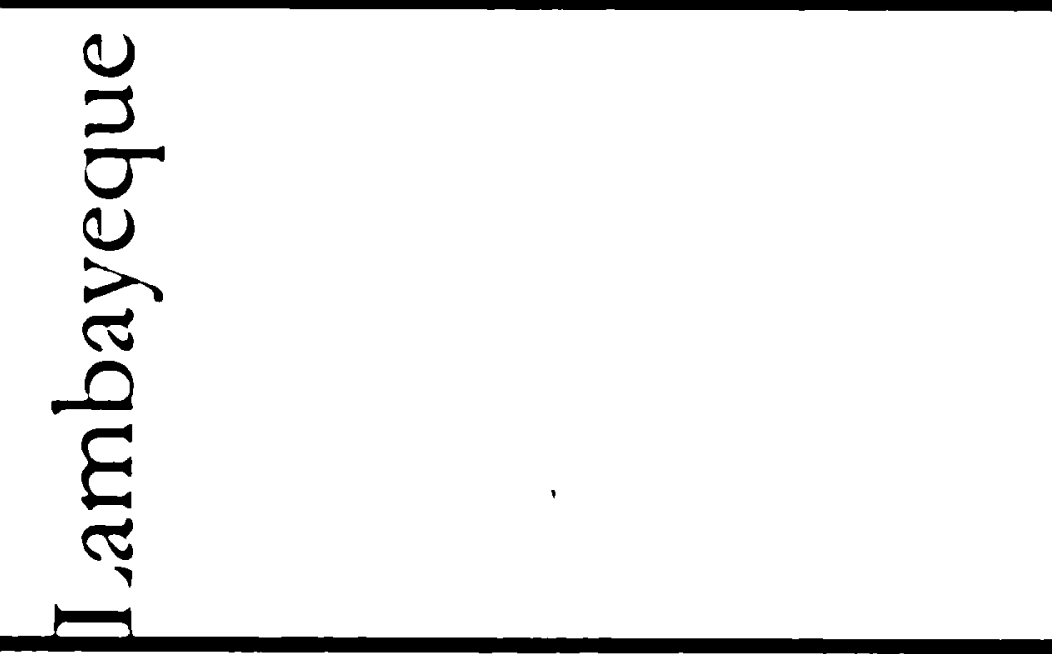 & 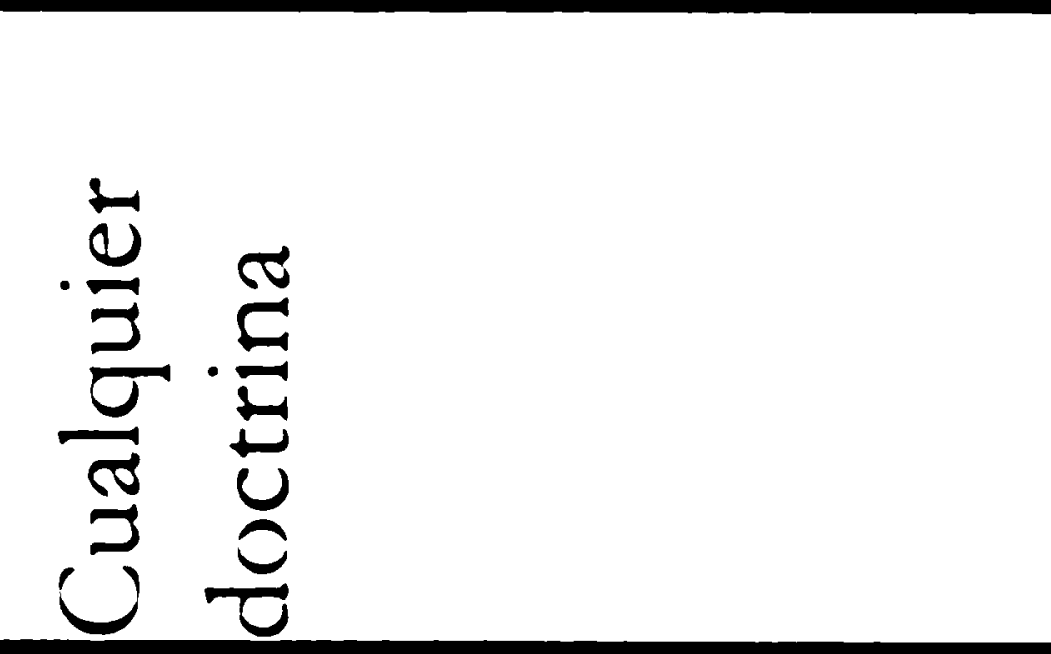 & 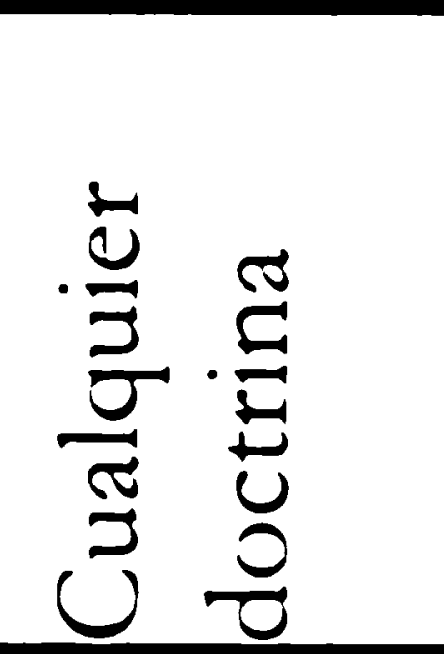 \\
\hline 路是 & 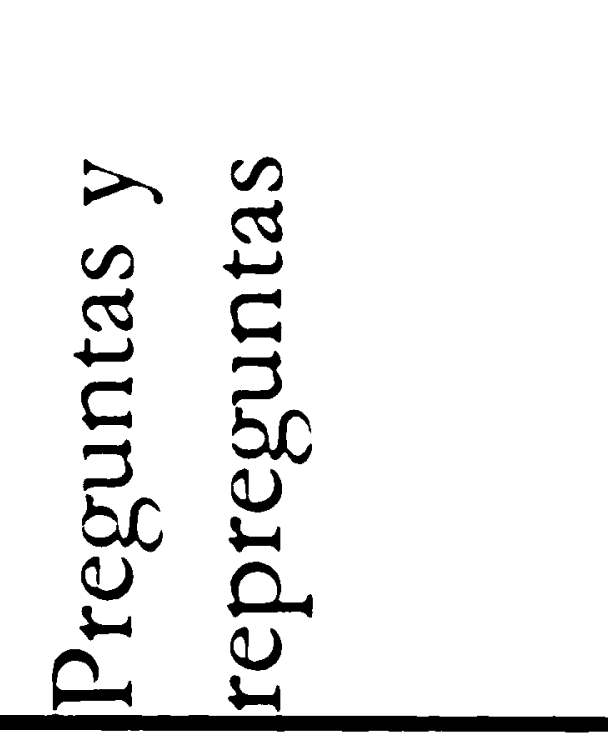 & 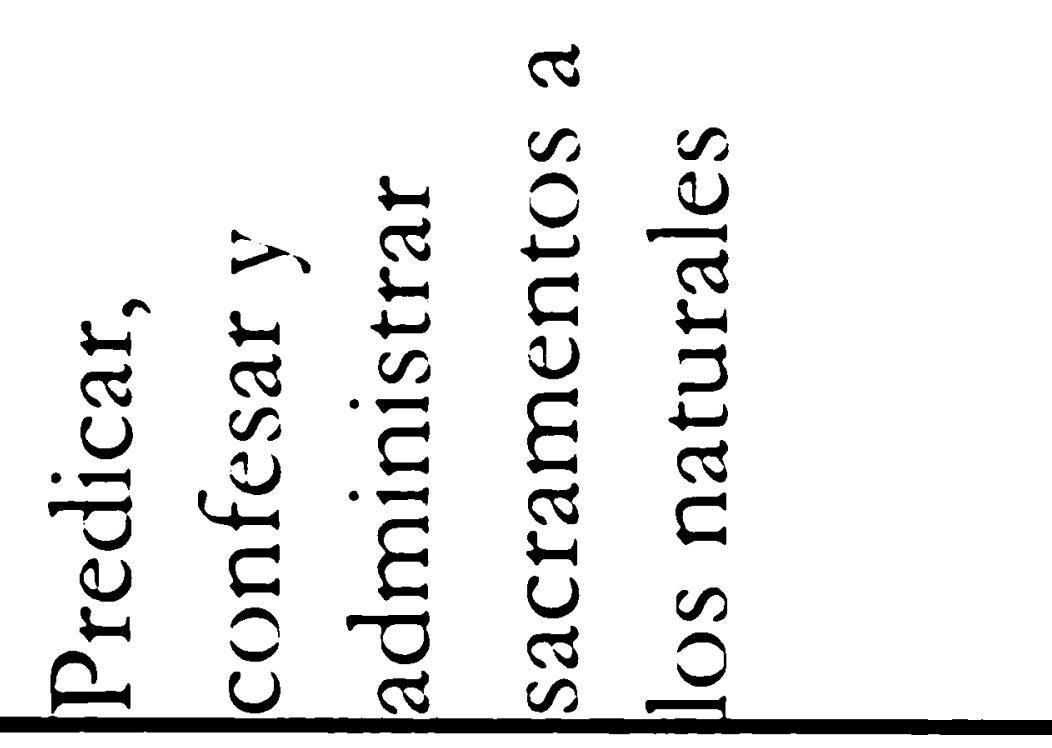 & 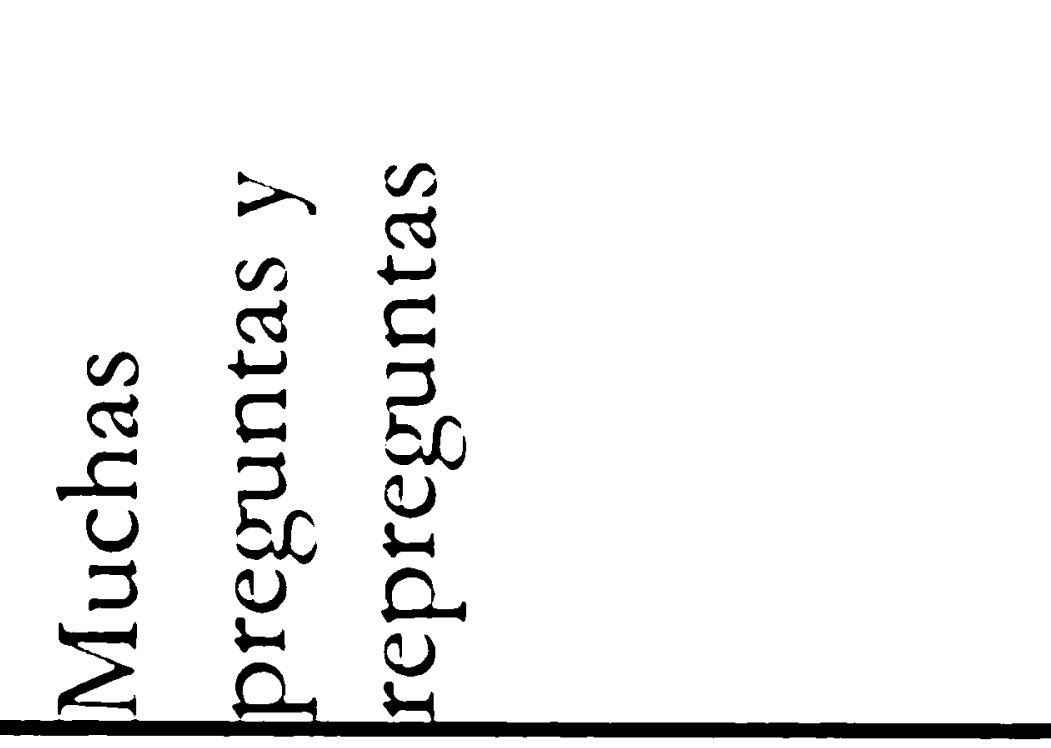 & 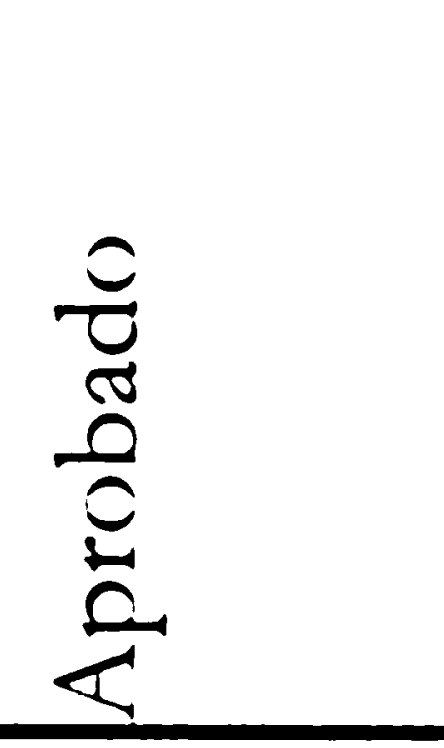 \\
\hline S & 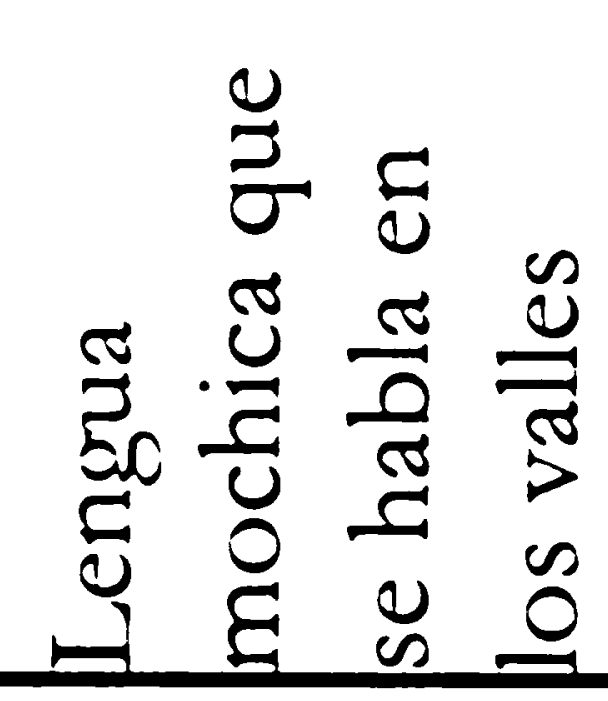 & 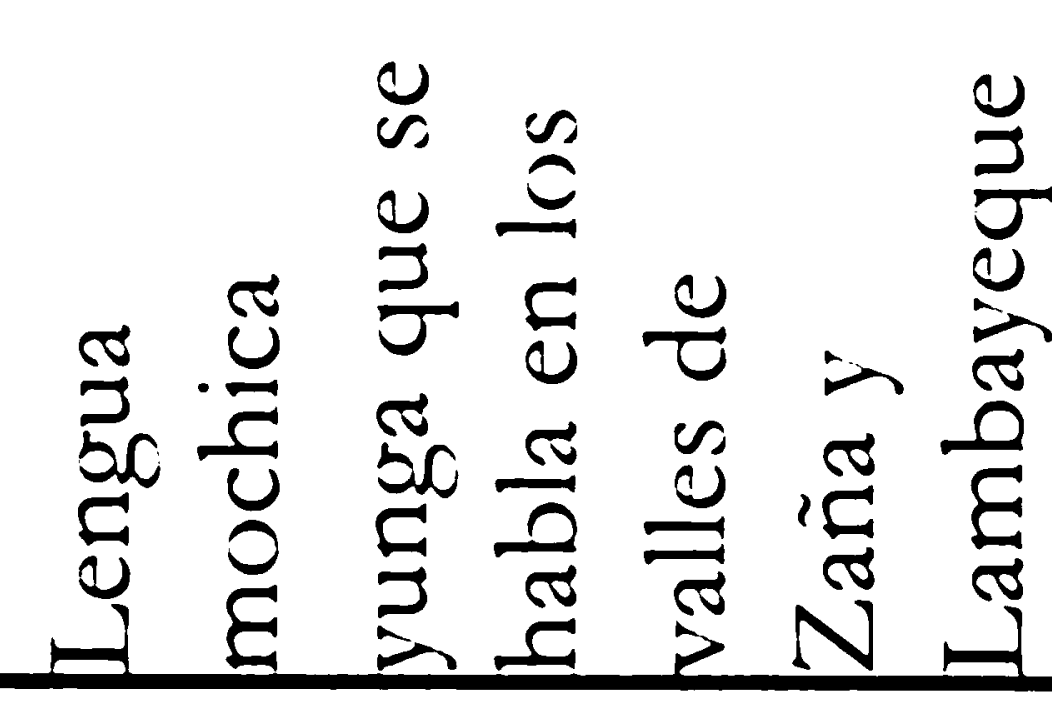 & 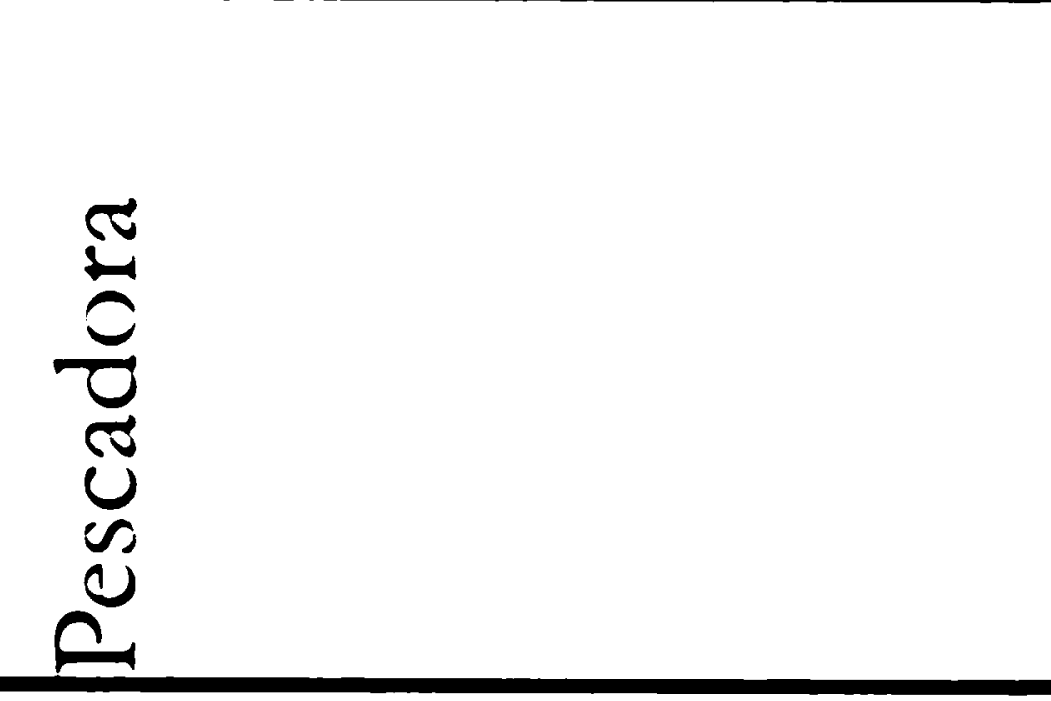 & 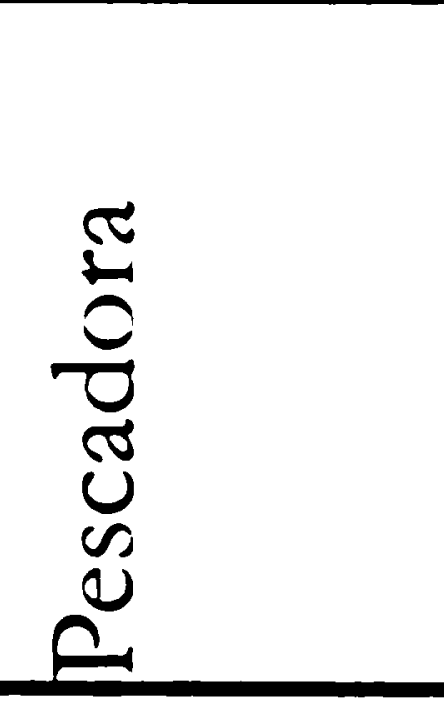 \\
\hline 号 & 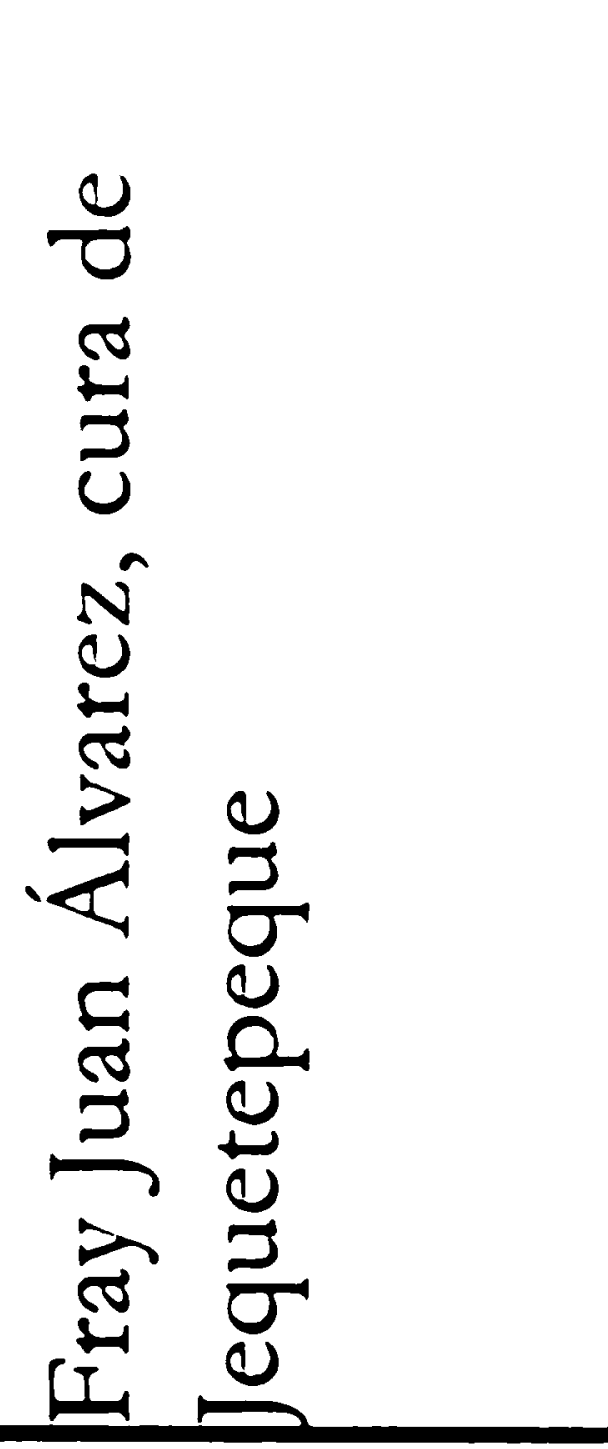 & 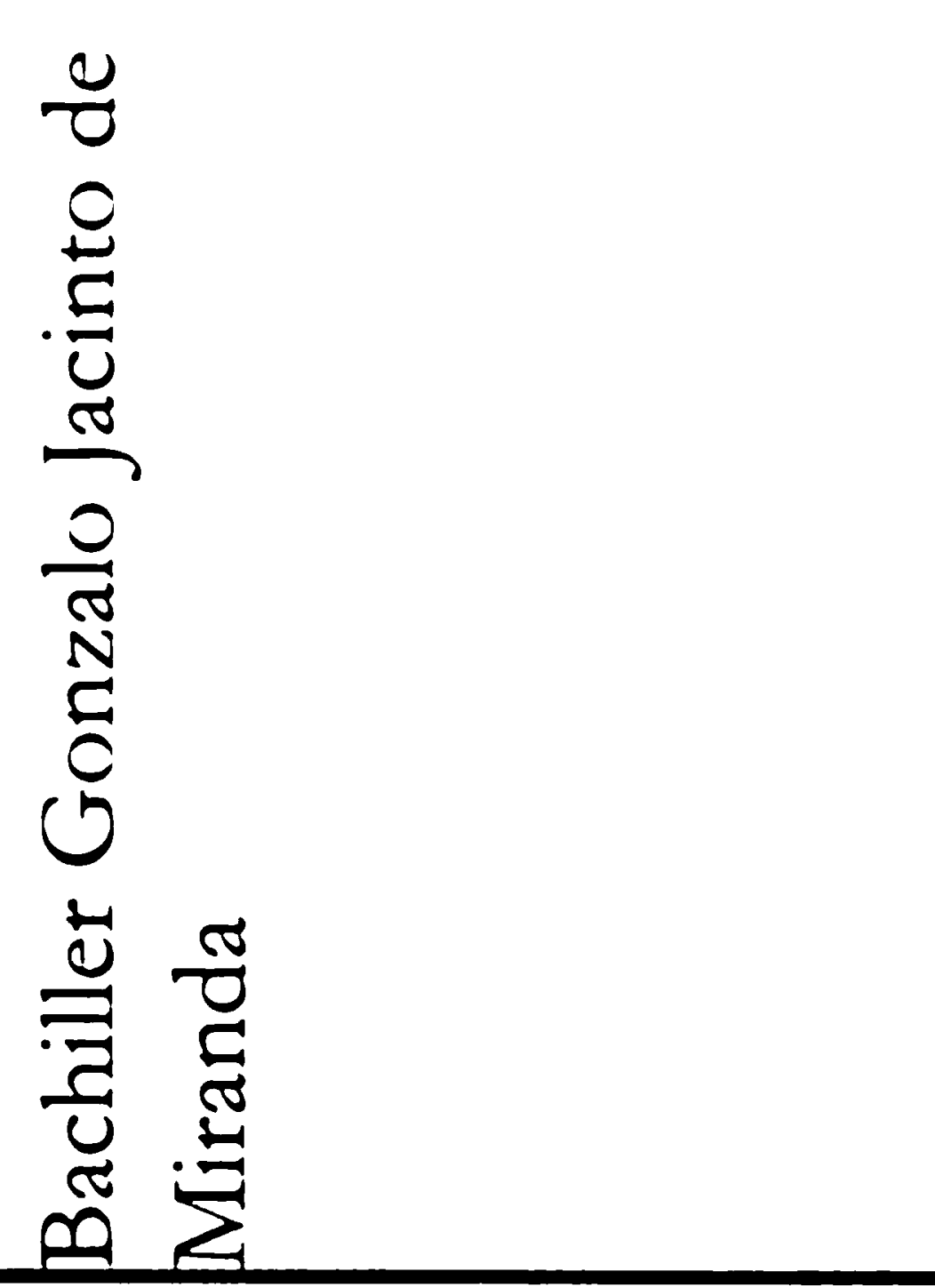 & 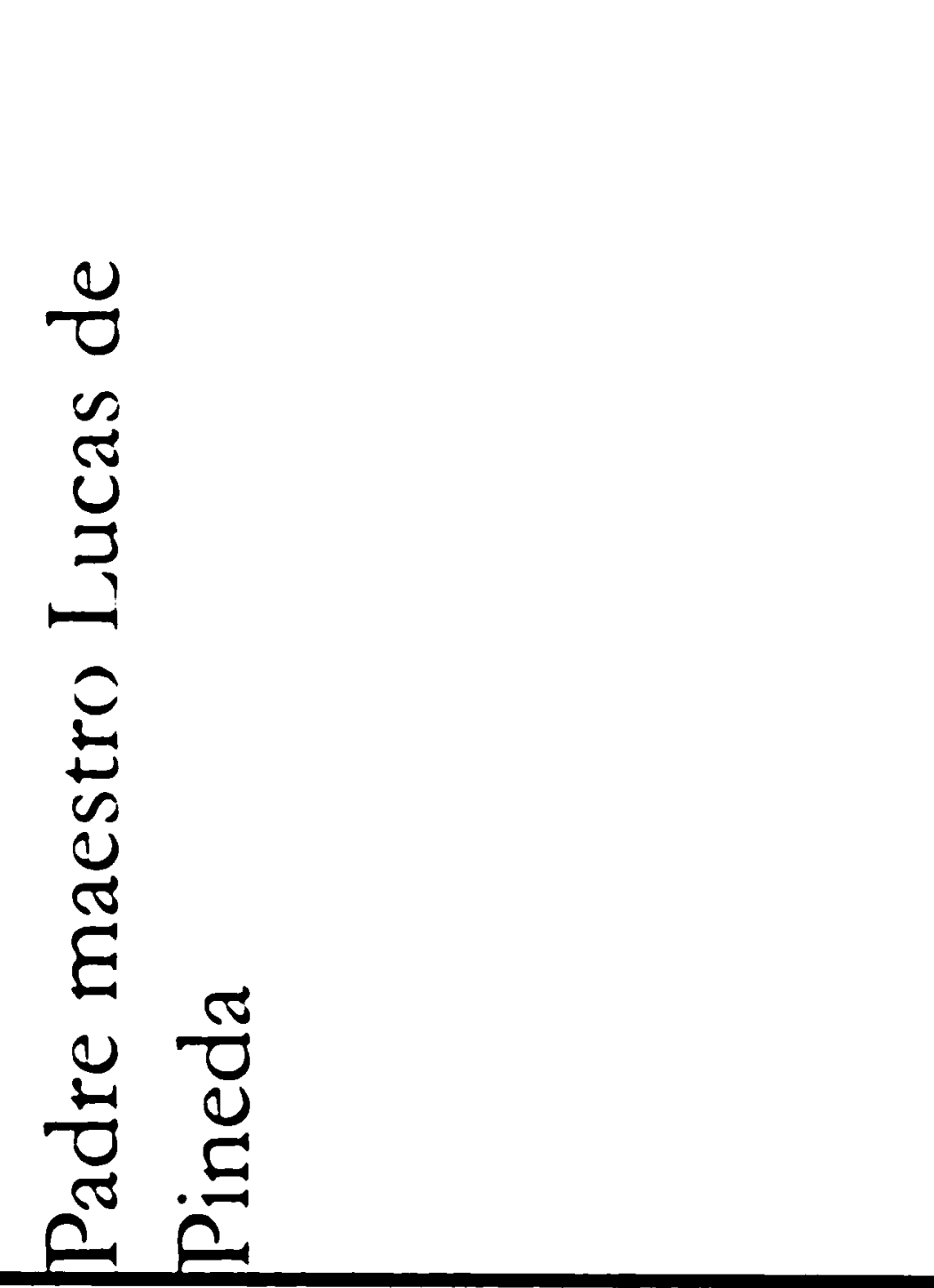 & 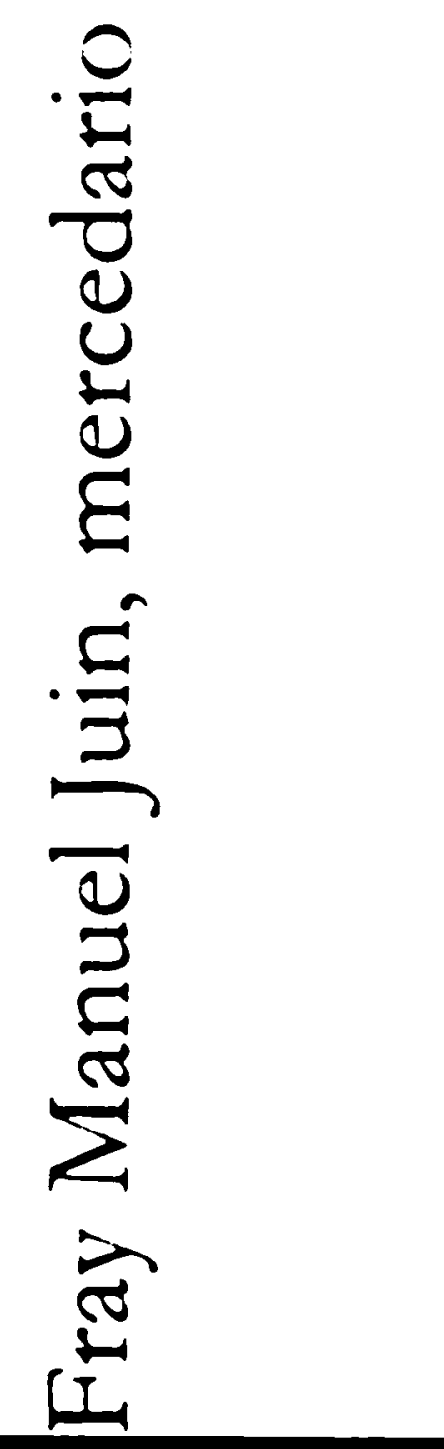 \\
\hline 足 & 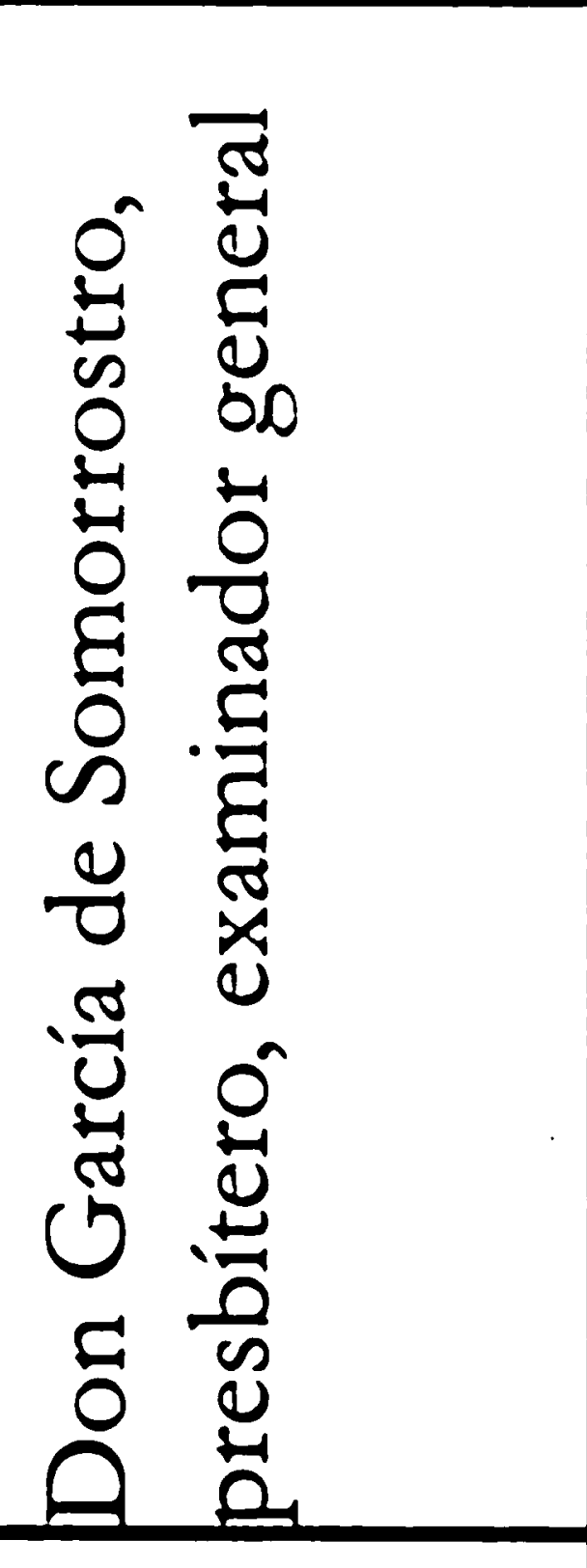 & 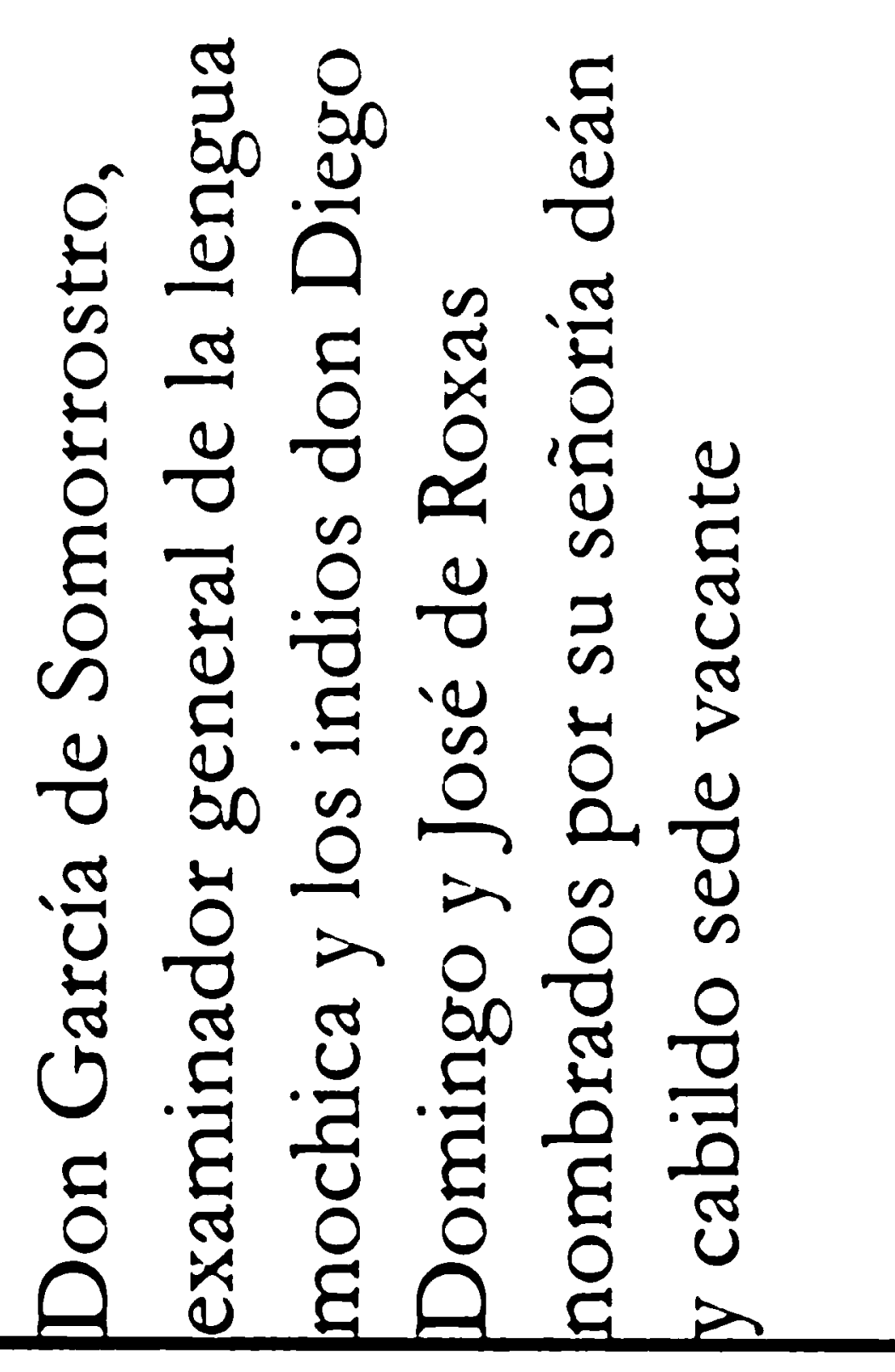 & 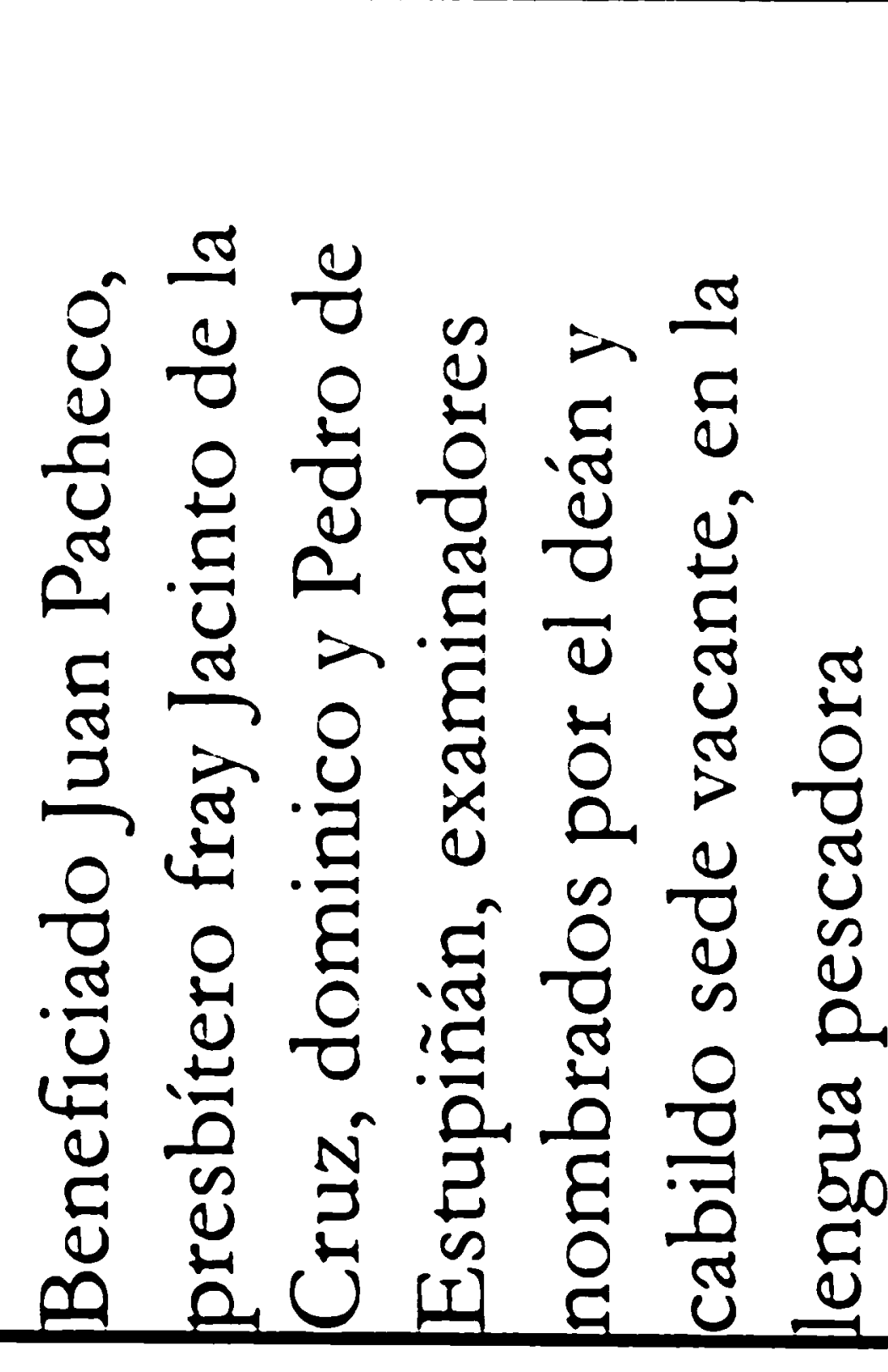 & 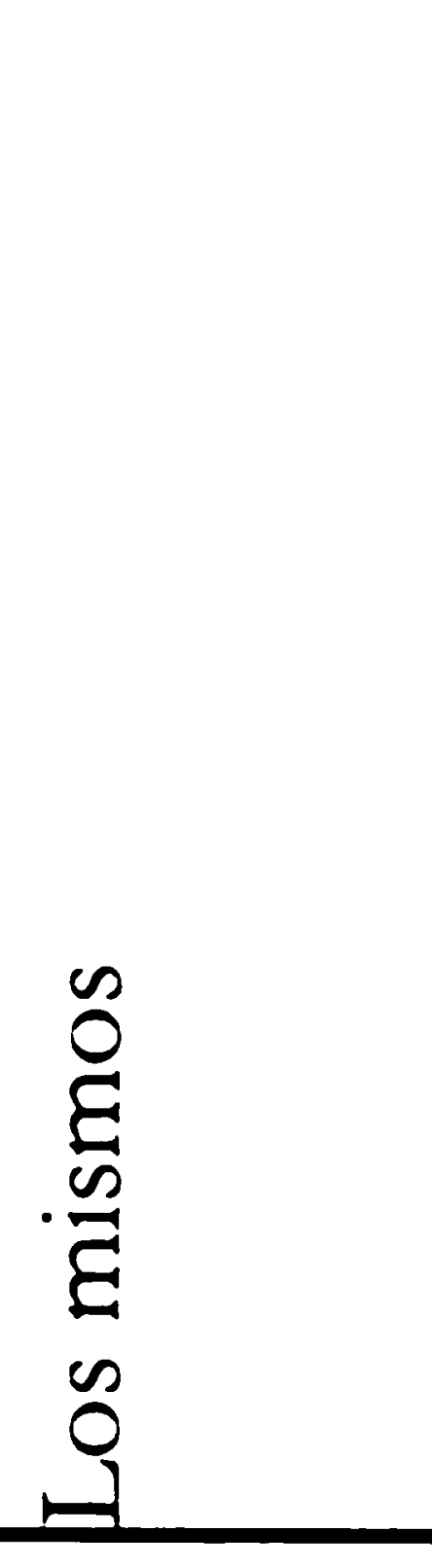 \\
\hline 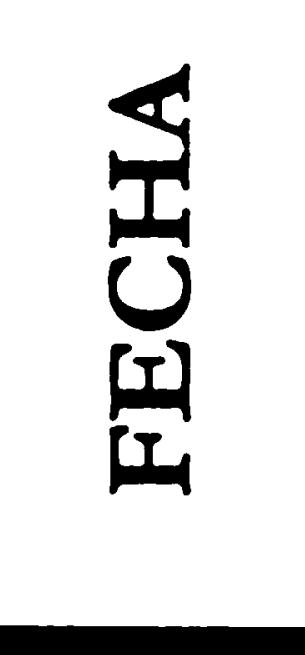 & 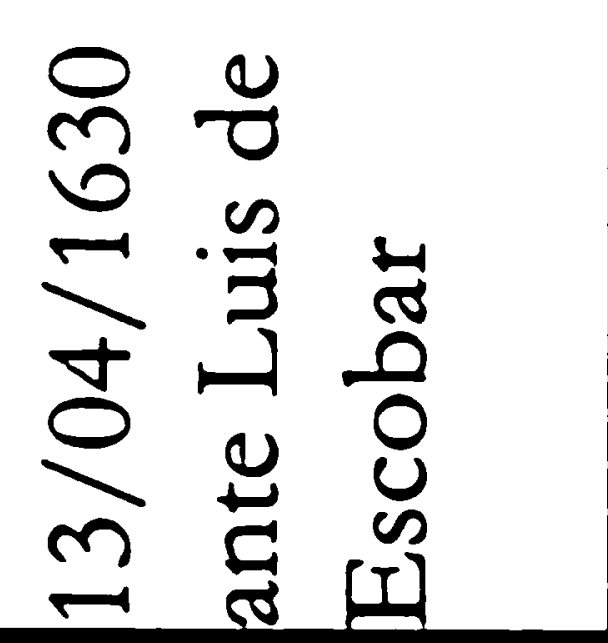 & 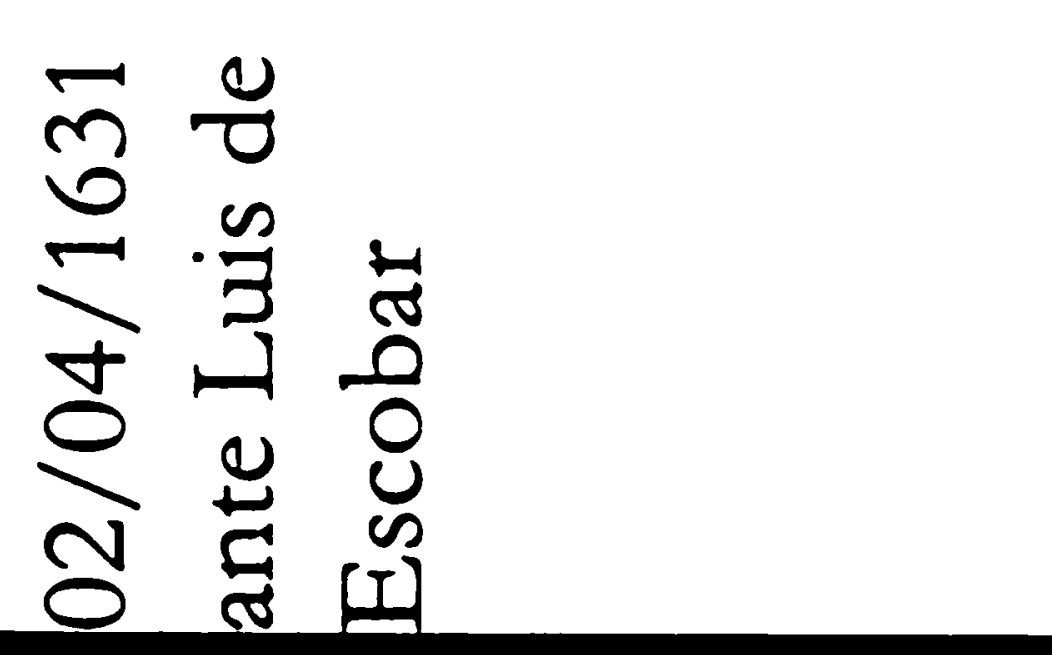 & 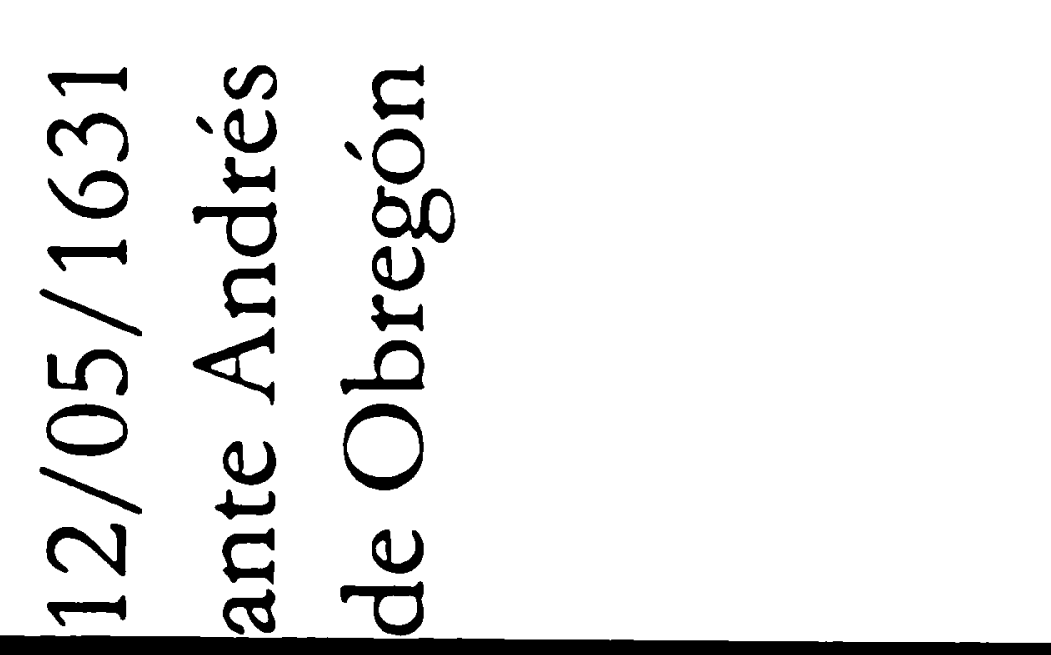 & 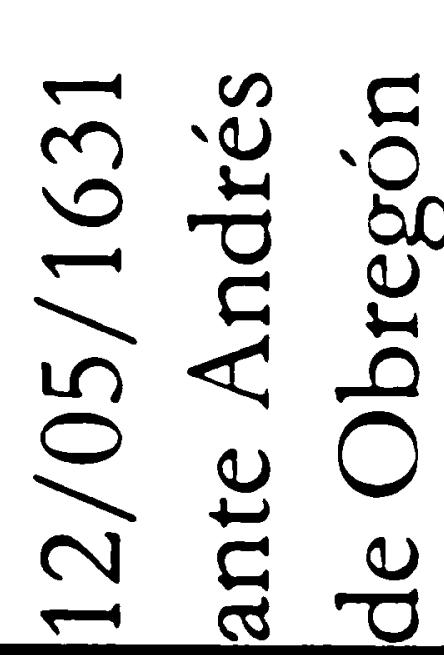 \\
\hline
\end{tabular}


JoSE ANT(ONIC S.ILLAS GARCIA

\begin{tabular}{|c|c|c|c|}
\hline $\begin{array}{l}Z \\
0 \\
0 \\
0 \\
0 \\
0\end{array}$ & 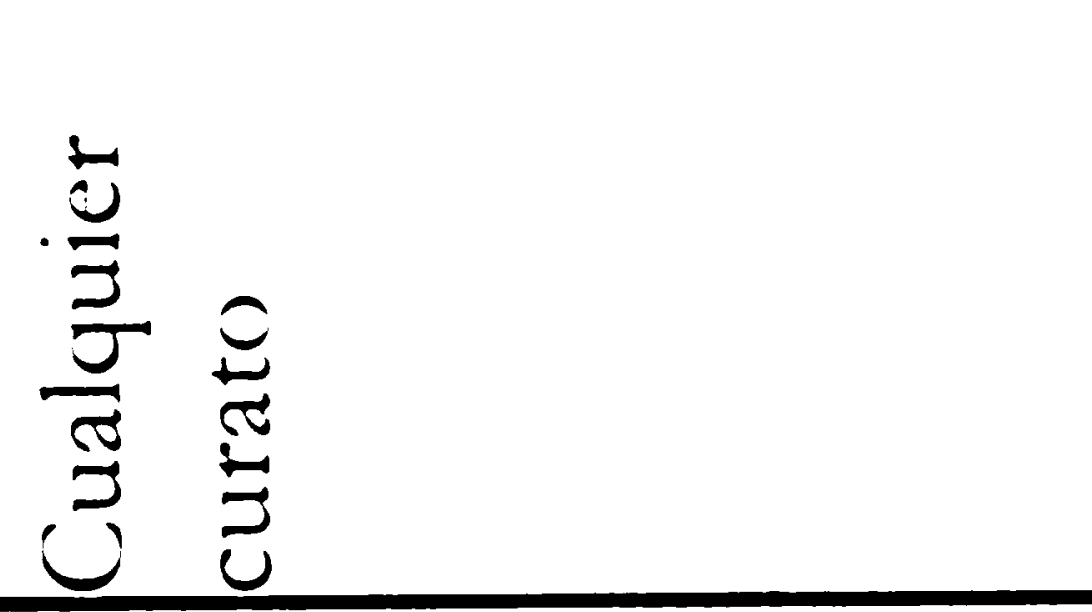 & 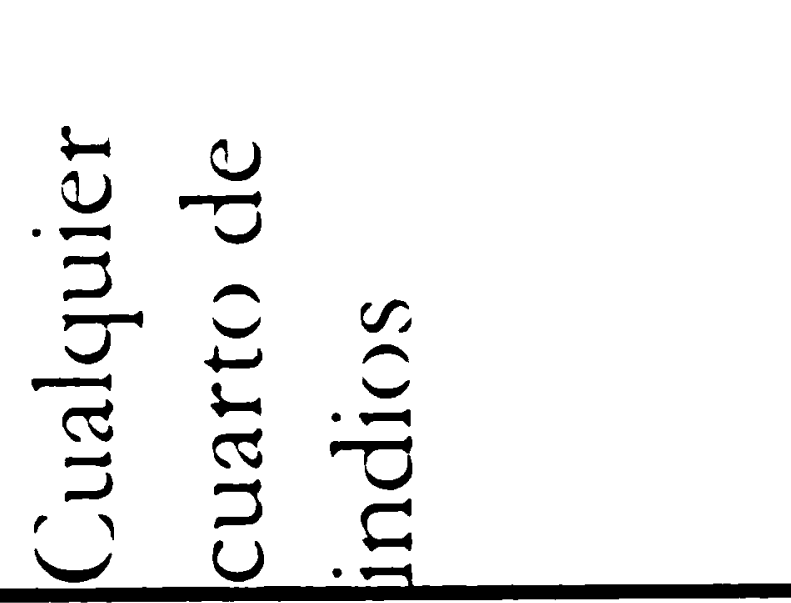 & \\
\hline$\underbrace{\infty}_{\infty} \frac{1}{\infty}$ & 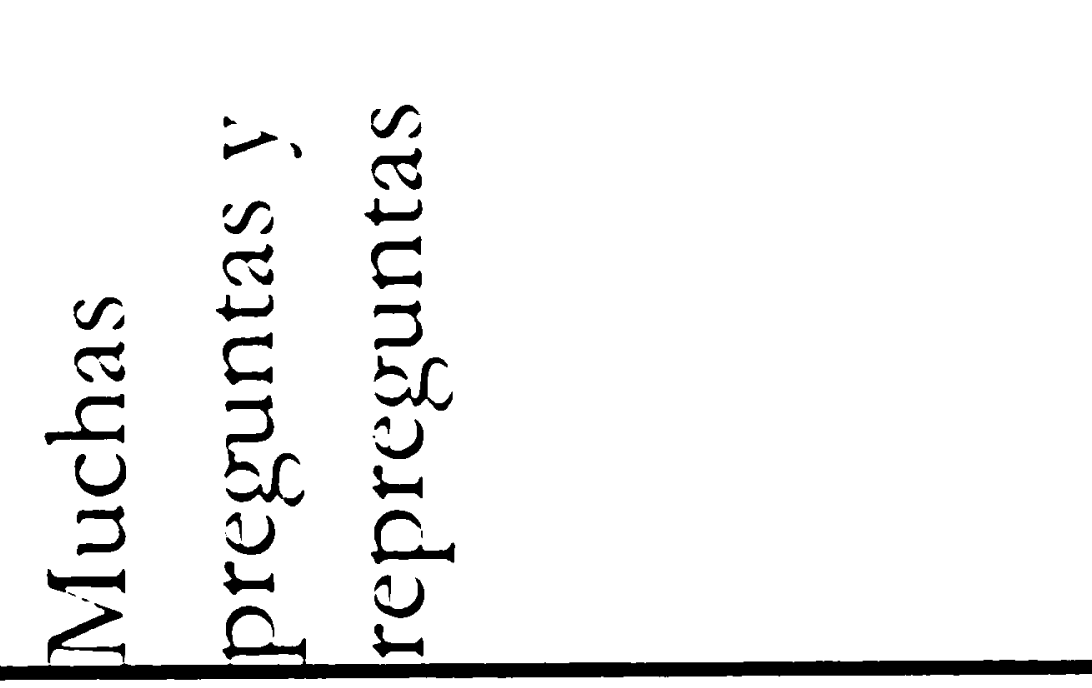 & 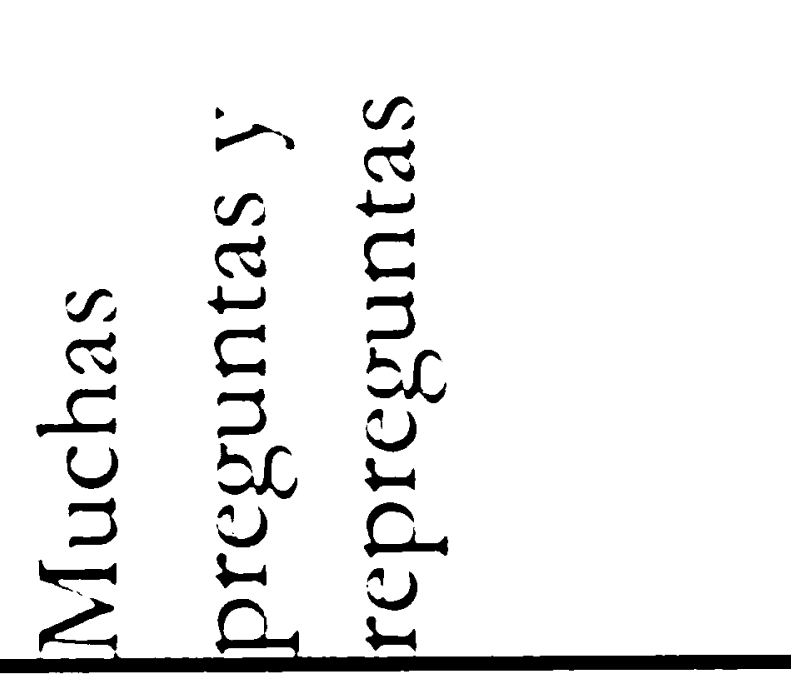 & 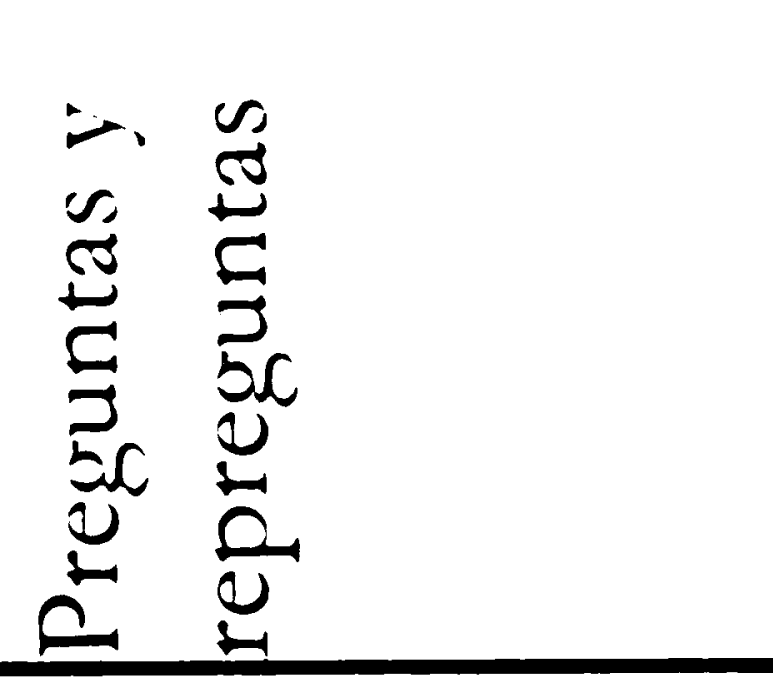 \\
\hline 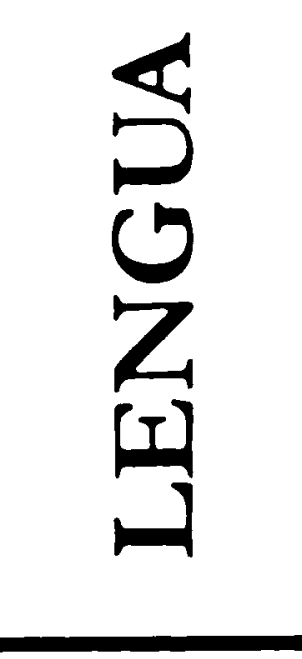 & 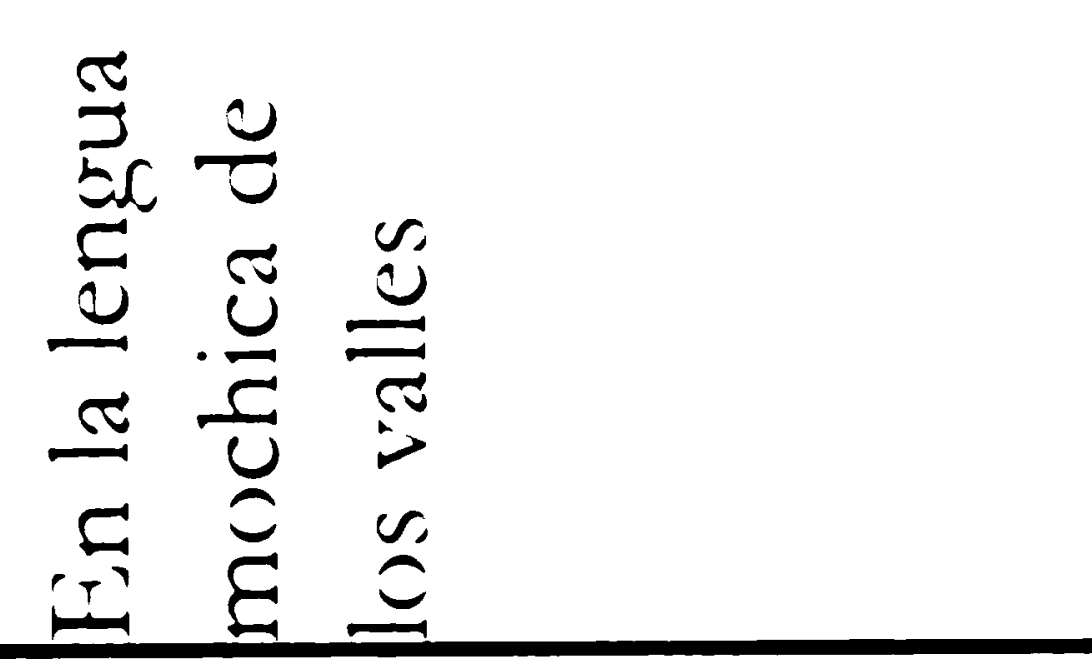 & 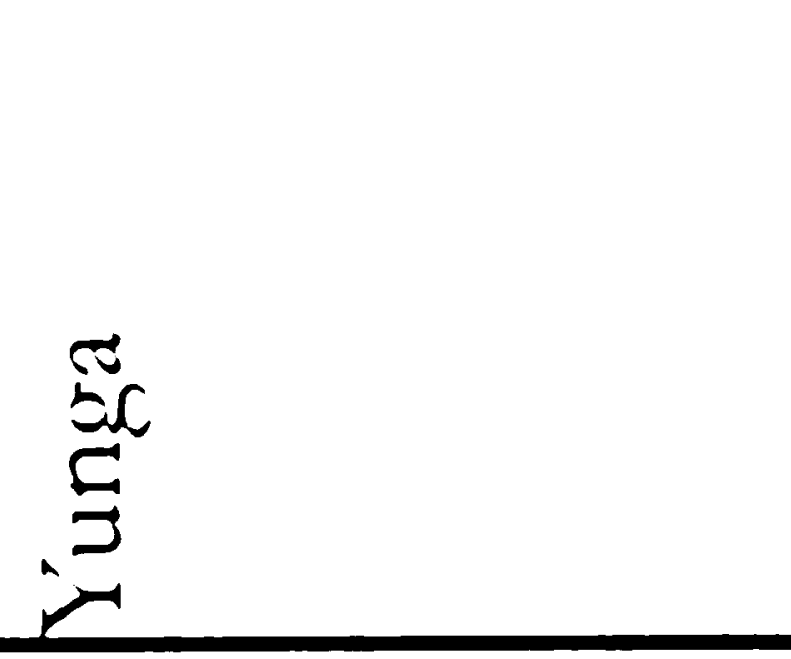 & 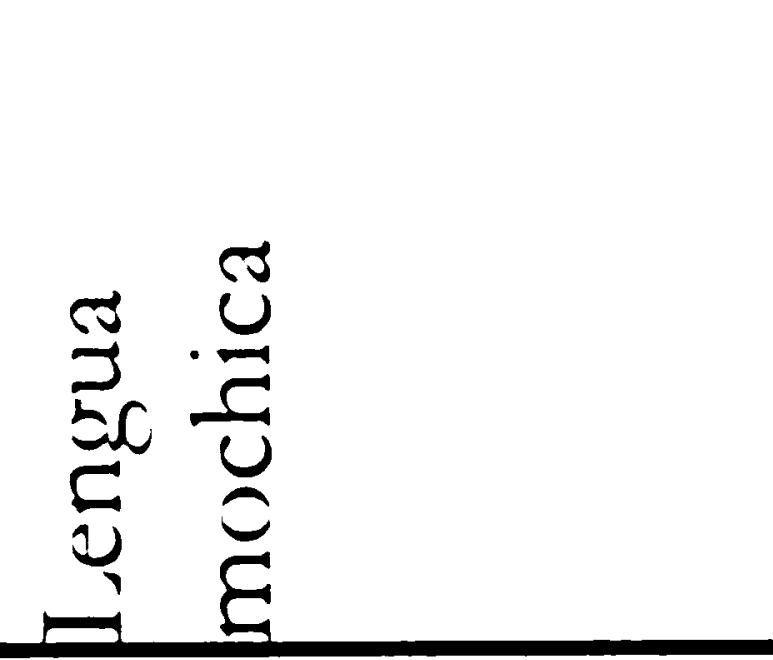 \\
\hline 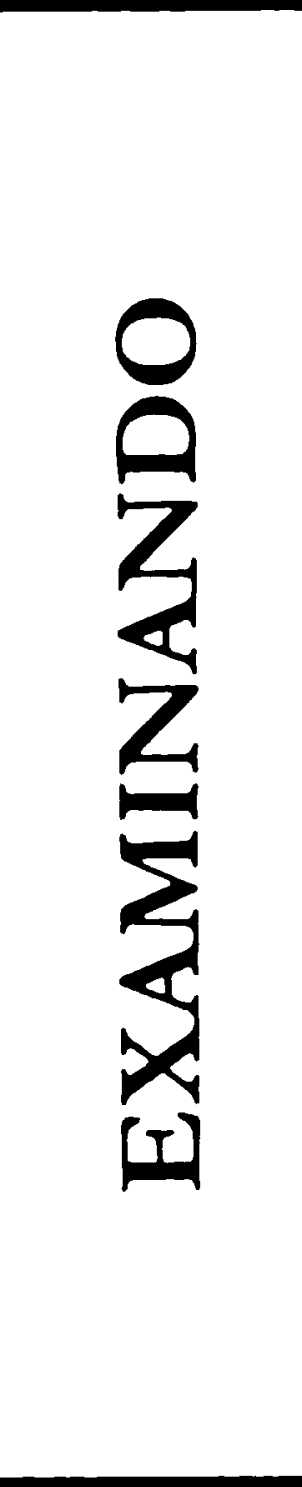 & 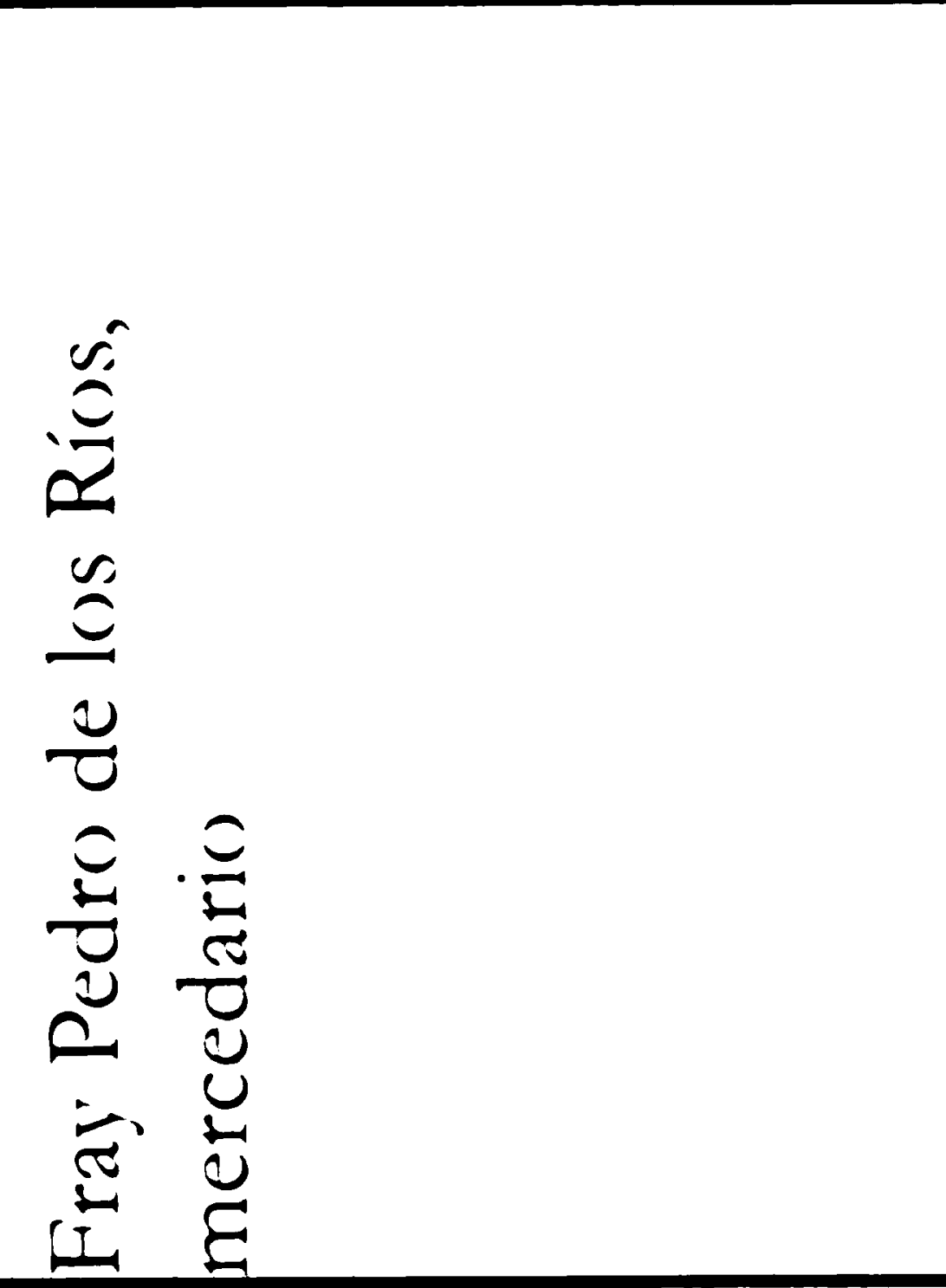 & 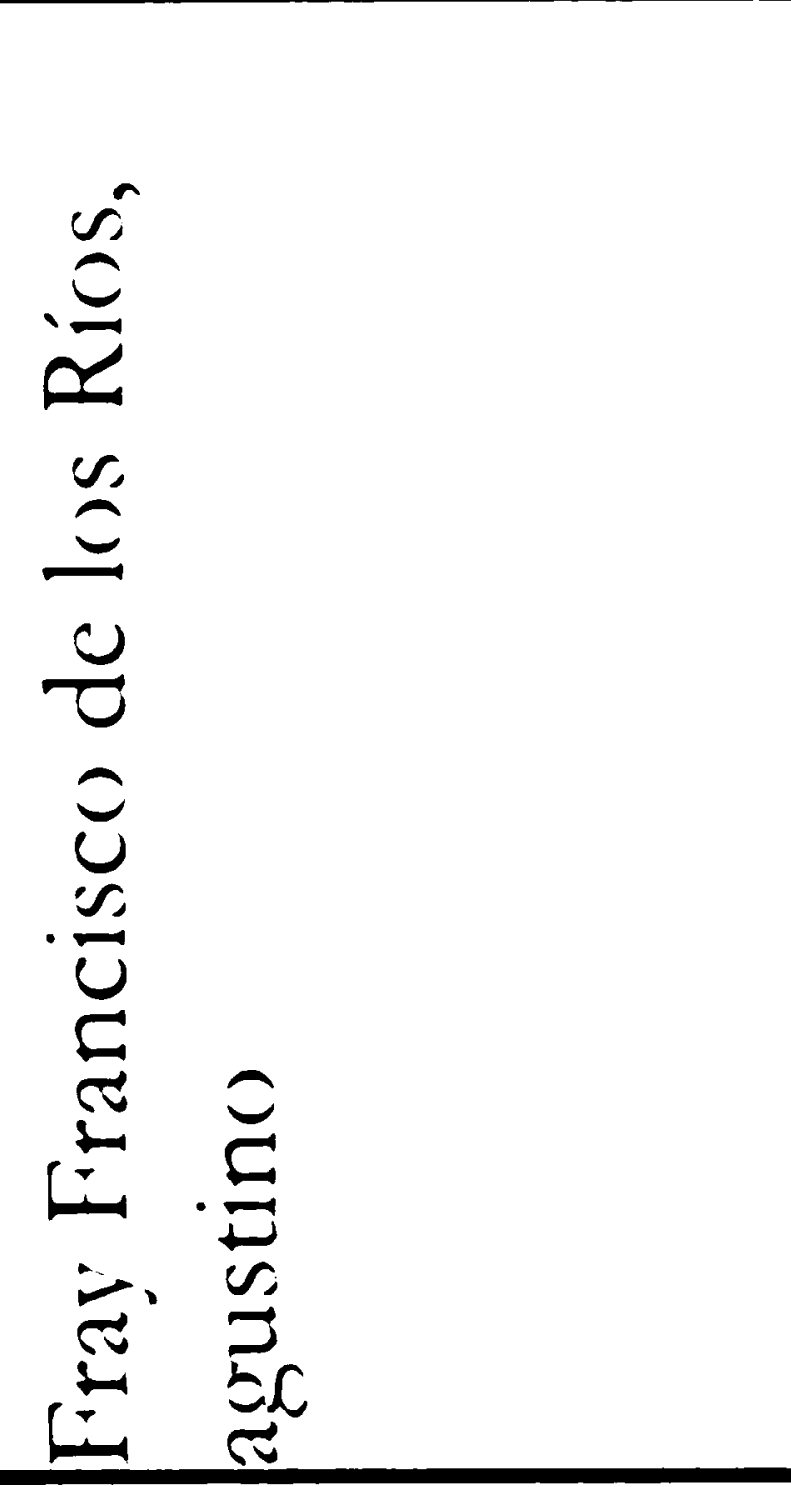 & 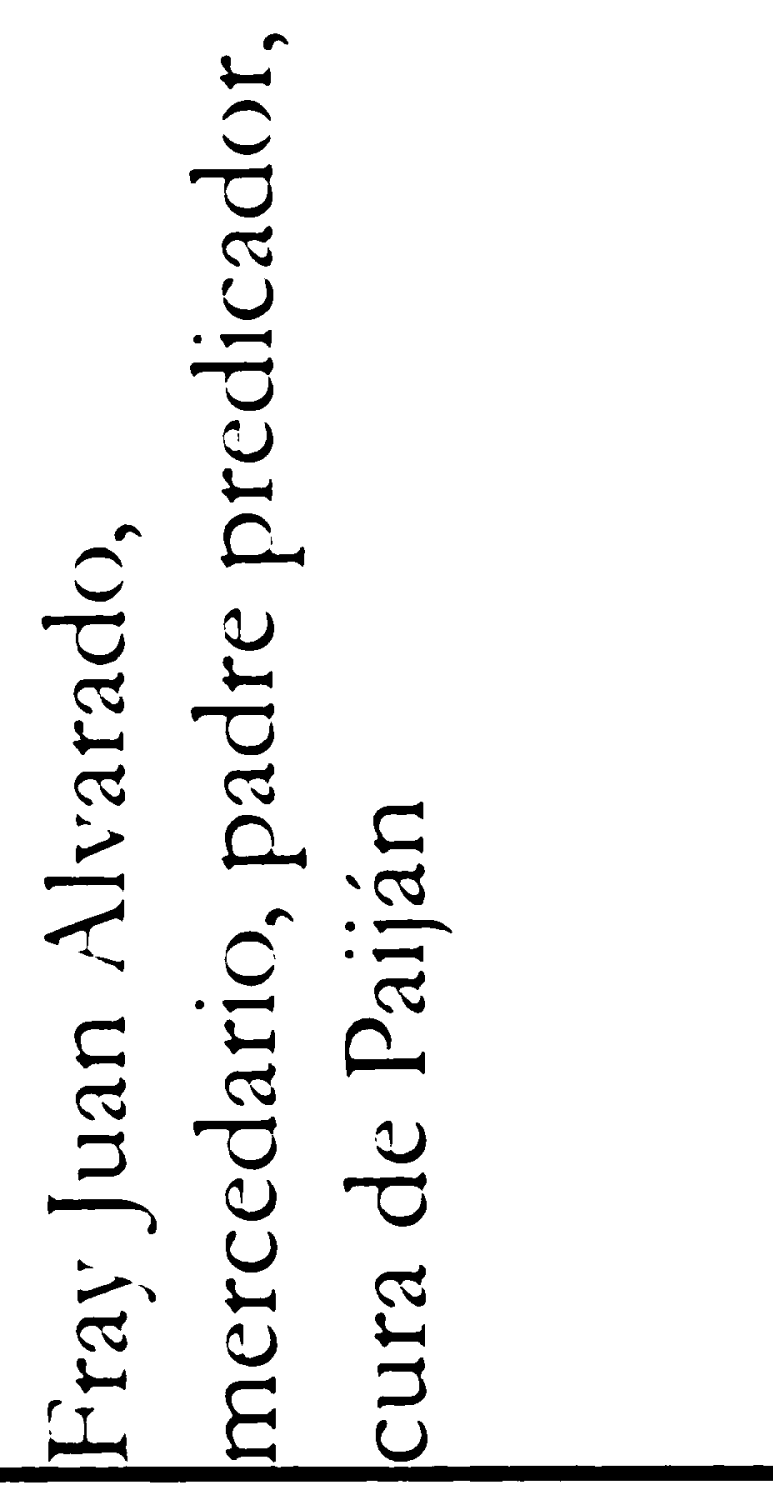 \\
\hline$\frac{8}{2}$ & 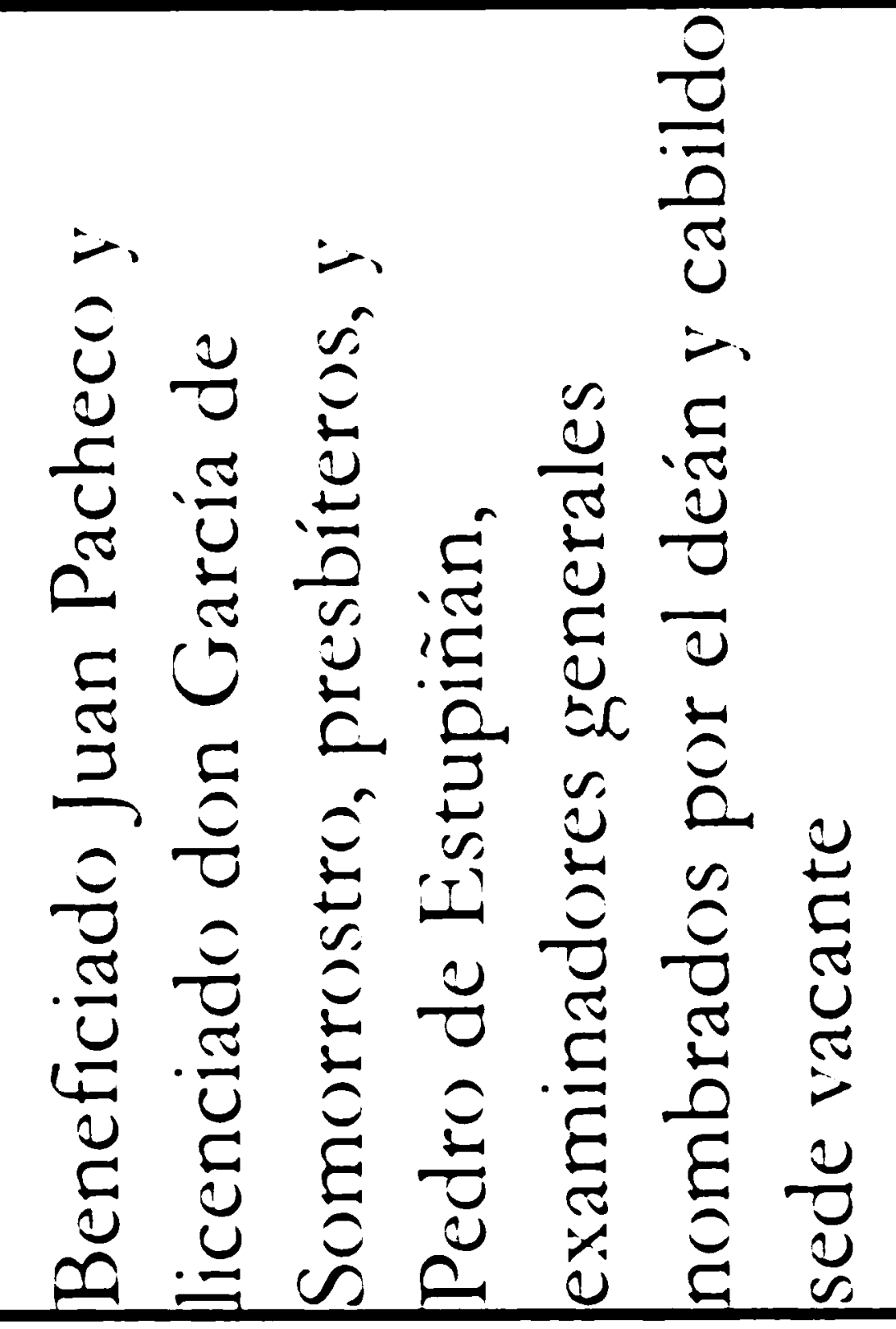 & 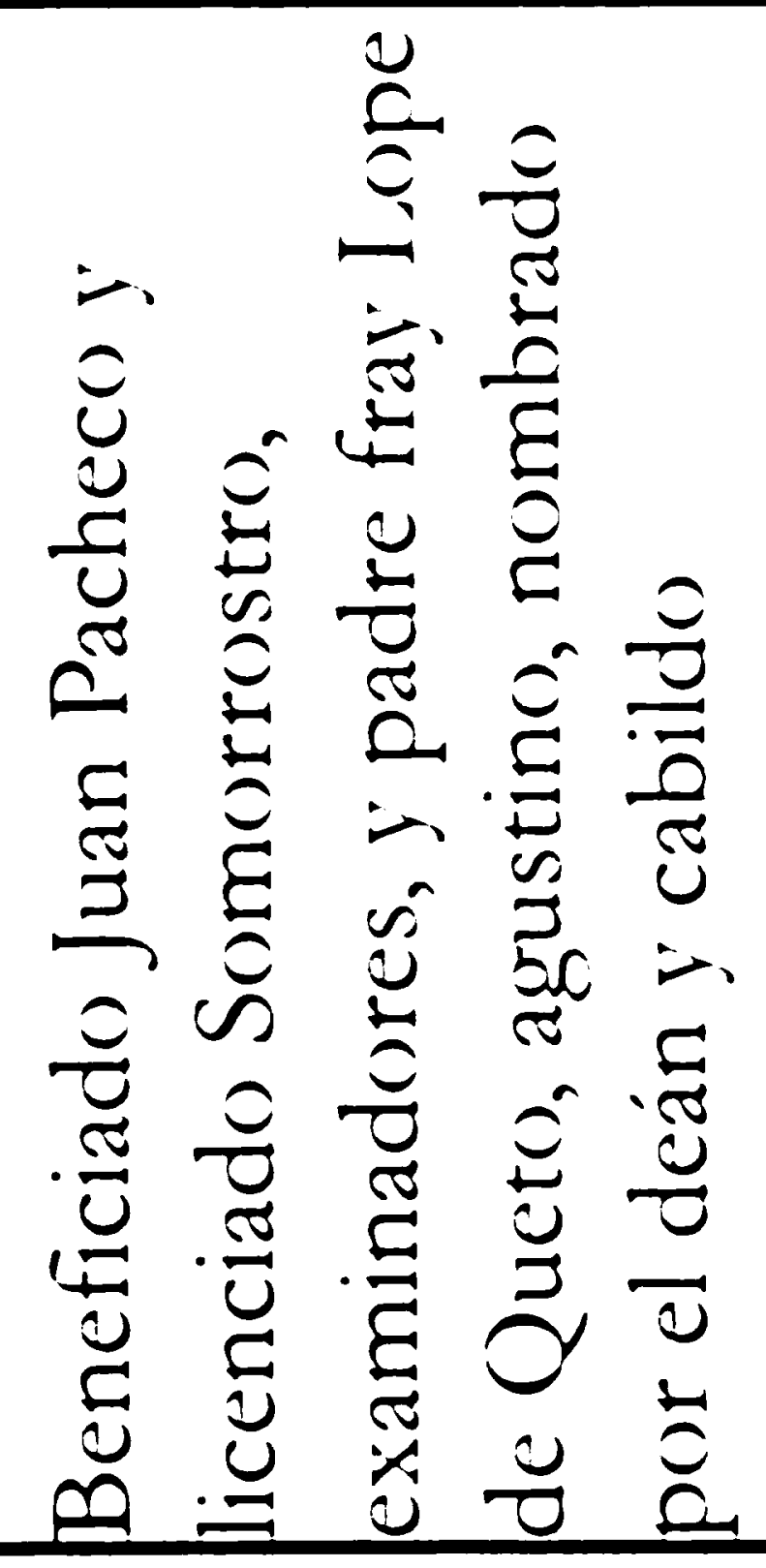 & 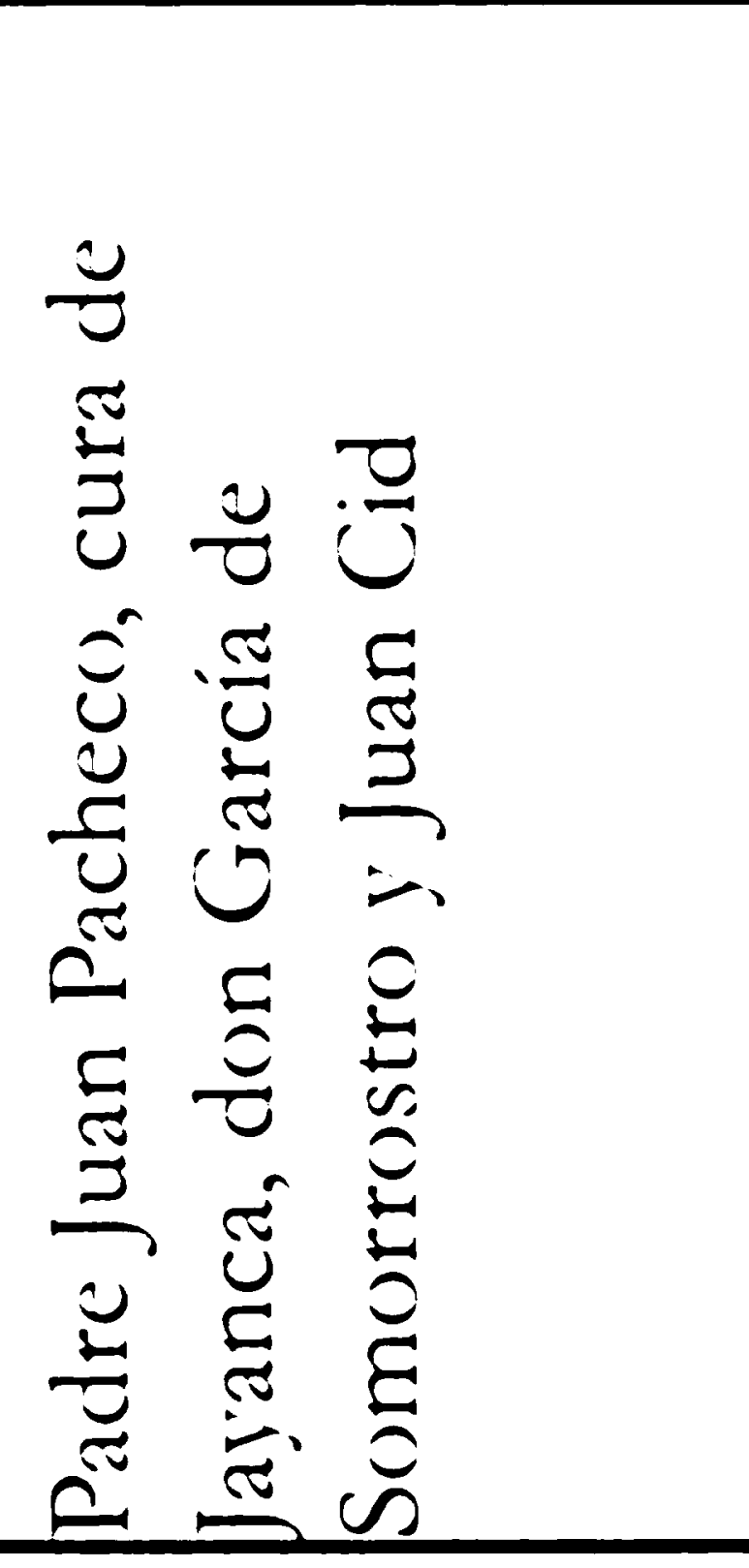 \\
\hline$\underset{\substack{I \\
I}}{S}$ & 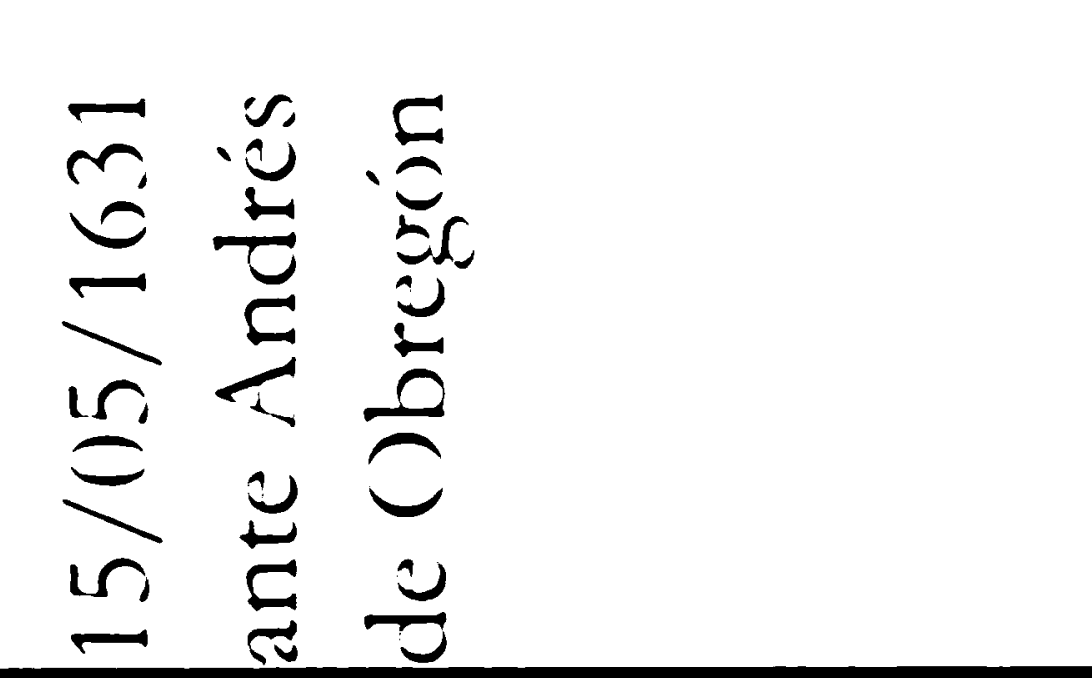 & 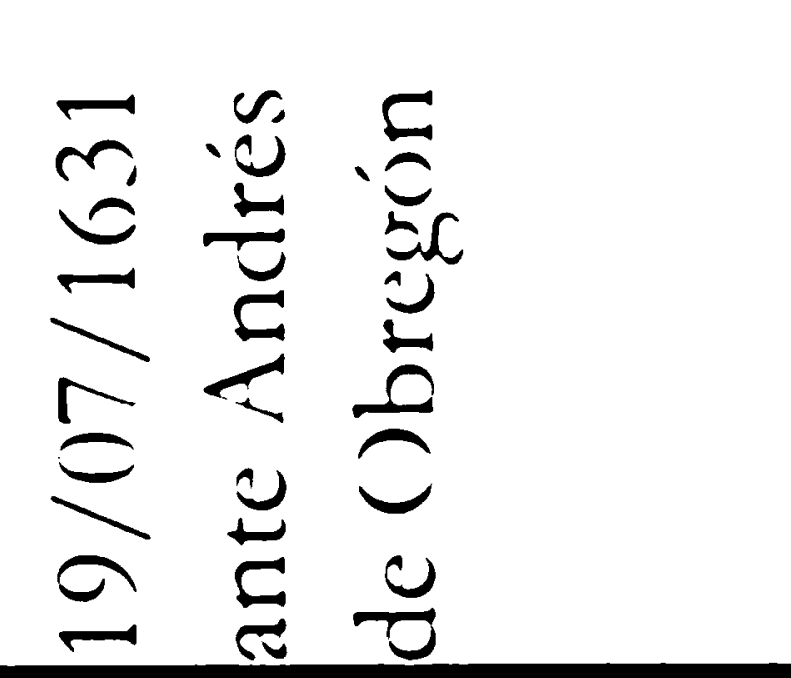 & 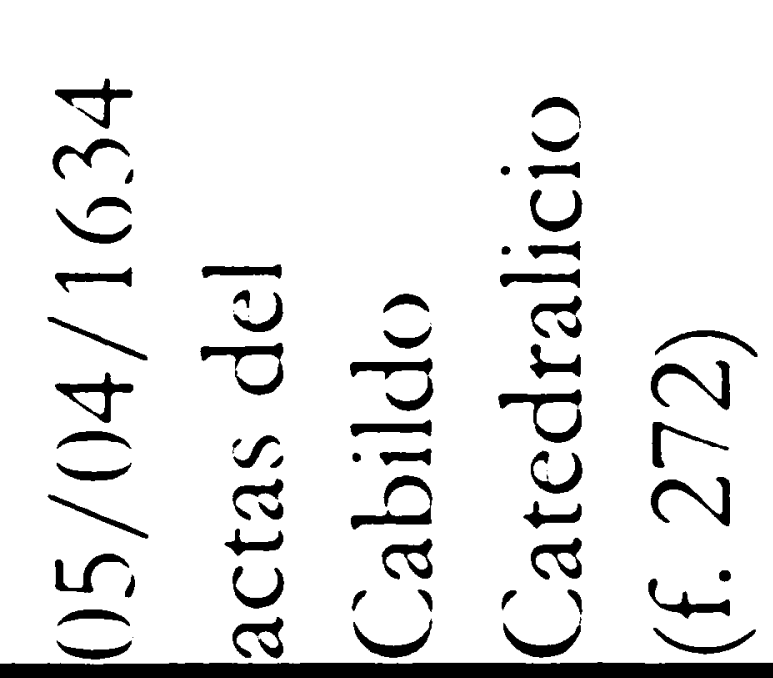 \\
\hline
\end{tabular}


La información proporcionada por Zevallos Quiñones (1996) permite, ciertamente, tener una idea cumplida de quiénes aprendieron el mochica y en qué circunstancia, toda vez que el absolver la prueba oral de los examinadores suponía que el sacerdote podía optar por alguno de los curatos que hablaban dicho idioma. Zevallos Quiñones brinda la siguiente información acerca de la evolución de los exámenes curales: «Al acabar el siglo XVII llegó a ser suficiente para las pruebas un Examinador General, cesando así los jurados escogidos; al promediar el XV'III desapareció la división previamente enunciada de lengua de los llanos y lenguas de la sierra. De 1765 a 1776 el Cabildo no elige sino mantiene por costumbre al titular anterior. En 1779, tan solo se pone a 6 examinadores para los curatos quechuas de la sierra y ninguno para los llanos. La lengua mochica había muerto» (1996: 14).

Ahora bien, siguiendo lo establecido por el Concilio de Trento, se realizó el tercer Concilio Limense, que hacia 1584 publica la Doctrina christiana en las lenguas quechua y aimara. En la epístola sobre la traducción que se encuentra al comienzo de dicha obra (en una página sin numerar), ${ }^{2}$ se lee que solamente deben usarse para estas lenguas las traducciones aprobadas por el concilio provincial y se añade: «[...] en las de mas lenguas que ay muchas, y muy diversas, esta proueydo $\tilde{q}$ los Prelados en sus Synodos diocesanos, o cõ la mejor comodidad que les parezca, hagã junta de lenguas de personas doctas y religiosas, para que de cõformidad se haga la traducciõ de este mismo Catecismo, y hecha assi cõ la

2. Era una costumbre en las ediciones de la época que las primeras páginas de las obras no se numerasen. 
dicha auctoridad se publique, y nadie vse otra alguna en aquella lẽgua. Y no por esto se quita, que los que tuuieren talento, no ayuden con su lengua y predicaciõ a la doctrina de los Indios».

En 1607, Oré publica la traducción de la Doctrina cbristiana al mochica. Sobre los autores de la traducción dice: «La Mochica fue traduzida por Sacerdotes seculares, y regulares approbada por el Illustrissimo Arçobispo de los Reyes» (Oré 1607: 385). Estos textos, sin embargo, parece que no tuvieron la difusión requerida, por las experiencias que relata Fernando de la Carrera. En efecto, De la Carrera menciona que los indios confundían a Dios con el patrón del pueblo San Martín de Reque, además de persistir en antiguas prácticas religiosas de origen precolombino. Cierto día, hablando con el cacique del pueblo, este le dijo: «que quiere v[uestra] $m$ [erced] si nos hablan en lengua Castellana? que aunque la entendemos, no es mas, que lo necessario, para la comunicacion de los Españoles» (Carrera 1644: sin numeración).

Estas circunstancias motivaron a Fernando de la Carrera a escribir su ya clásica obra. En ella, no solamente trata sobre las cuestiones gramaticales, sino que también traduce - nuevamente- las oraciones de la Doctrina christiana y adiciona algunos textos religiosos que no aparecían en ella. Una de esas oraciones es la fórmula para administrar el sacramento de la comunión. El texto no tiene traducción al castellano, pues De la Carrera nunca imaginó que la lengua iba a desaparecer. A lo largo de su gramática da a entender que quien quiera aprender esta lengua la "perfeccionará con el uso entre los Indios». Hoy no existe ningún hablante materno de mochica. El propósito del presente artículo es ofrecer una traducción razonada de esta fórmula. 


\section{Corpus}

Dicho texto no aparece en la obra de Luis Jerónimo de Oré de 1607. Así, bajo el título «Para administrar el Santissimo Sacramento del Altan», Fernando de la Carrera (1644: 257) brinda el siguiente texto, encabezado por la frase latina «Domine non sum dignus, etc.»:

«Mollpæc mæiñ çiec Iesu Christo, inoiñca moixll tæpæco mæiñ polenic, tzhango mæiñ çiec ñop xlloco, santaio tzhæng ssap mæn maiñ, epaca ixllæss, aieçæn mæiñ moix echæm peño, peiñna ixllæssen quich efædo».

\section{Metodología}

Con el propósito de analizar la fórmula, la transcribiremos segmentándola correctamente de acuerdo con los siguientes criterios: (a) la división entre palabras se hará teniendo en cuenta los lexemas que existen en la frase; a guisa de ejemplo, la frase nominal <moixll> compuesta de mo 'determinante' + ixll 'pecado' irá separada: mo ixll "este pecado"; (b) los morfemas que puedan ser analizados dentro de la palabra se segmentarán por medio de un guión. Por ejemplo, en el lexema <ixllass> se distingue una raíz de lexema ixll 'pecado' y un morfema de posesión ass. De ahí que lo transcribamos como ixll-ass; (c) los clíticos y las frases posposicionales se transcribirán con subraya; de esta manera, lo que aparece como <inoiñca > será segmentado como ino_iñ-ca "no seré", donde ino es la negación, iñ es la primera persona del verbo 'ser', que se adjunta a la negación como clítico, y ca es el futuro. Nótese que entre iñ y ca hay un guión, 
José Antonio SALAS García

pues ambos elementos forman parte del mismo verbo. Con estas precisiones, el texto nuevamente trascrito queda como sigue:

Mollpæc mæiñ çiec Iesu Christo, ino_iñ-ca mo ixll tæ-pæco mæiñ pol-e_nic, tzhango mæiñ çiec ñop xlloco, santaio tzhæng ssap_mæn ma-iñ, epaca ixll-æss, aie-çæn mæiñ moix e-chæm peño, peiñ-na ixll-æss-e_nqu-ich ef-ædo.

\section{Abreviaturas}

Antes del análisis es necesario presentar una serie de abreviaturas gramaticales que serán empleadas en la traducción de los textos mochicas:

$\begin{array}{lll}1 .^{\mathrm{a}} & = & \text { primera persona } \\ 2 .^{\mathrm{a}} & = & \text { segunda persona } \\ 3 .^{\mathrm{a}} & = & \text { tercera persona } \\ \mathrm{ABL} & = & \text { ablativo } \\ \mathrm{ADV} & = & \text { adverbializador } \\ \mathrm{COP} & = & \text { copulativo } \\ \mathrm{DET} & = & \text { determinante } \\ \text { FUT } & = & \text { futuro } \\ \mathrm{G} & = & \text { genitivo } \\ \mathrm{LOC} & = & \text { locativo } \\ \mathrm{NEG} & = & \text { negación } \\ \mathrm{OBJ} & = & \text { objeto } \\ \mathrm{PA} & = & \text { participio activo } \\ \mathrm{PP} & = & \text { participio pasivo }\end{array}$




$\begin{array}{lll}\mathrm{PS} & = & \text { posesión } \\ \neg \mathrm{PS} & = & \text { no posesión } \\ \mathrm{S} & = & \text { singular } \\ \mathrm{SUBJ} & = & \text { subjuntivo } \\ \text { (V) } & = & \text { vocal }\end{array}$

El signo ø se interpreta como un morfema que no tiene realización fónica pero es relevante para el análisis. Lo que va escrito entre los paréntesis angulados $<>$ refiere a las formas ortográficas tal. Lo que aparece escrito entre comillas simples ' corresponde a los significados de las palabras aisladas, y lo escrito entre comillas inglesas dobles " " corresponde a los significados inferidos de los textos.

\section{ANÁlisis}

Analizaremos este pasaje en cuatro frases determinando cada uno de los elementos gramaticales que las componen. Primero presentaremos la frase en mochica; luego ofreceremos una traducción palabra por palabra detallando la información gramatical de cada vocablo. Separaremos mediante un línea oblicua $(/)$ cada uno de los términos para que pueda ser más fácil seguir la traducción. Finalmente, brindaremos una traducción libre que recogerá el sentido general del texto en cuestión.

La primera es una frase vocativa:

1) Mollpæc mæiñ çiec-ø Iesu Christo señor/ 1. ${ }^{a}-\mathrm{S}-\mathrm{G} /$ señor-PS/ Jesucristo

Señor, mi señor Jesucristo. 
Era usual en mochica hacer la aposición a $<$ Mollpac $>$ 'señor', reiterando esto con la frase posesiva <maiñ çiec $>$ "mi señor". El mochica carecía de pronombres posesivos, por lo que empleaba el pronombre personal en genitivo. Una traducción absolutamente literal sería "de mí, señor" en vez de "mi señor".

La siguiente frase es una oración negativa:

2) ino_iñ-ca mo ixll-ø tæ-pæco mæiñ pol-e_nic, tzhango mæiñ çiec-ø ñop xlloco

NEG/1. ${ }^{a}-S-F U T / D E T /$ pecado- $\neg P S /$ ir-PA/1. ${ }^{a}-\mathrm{S}-\mathrm{G} /$ vientreG_LOC/2. ${ }^{a}-S-O B J / 1 .{ }^{a}-S-G /$ señor-PS/recibir/digno

(Yo) que llevo este pecado en mi vientre no seré digno de recibirte, mi señor.

La partícula negativa <ino> la traducimos como 'no'. El verbo copulativo aparece como $\langle$ iñca $>$. Al adjuntarse el verbo como clítico a la partícula negativa, entonces hace caer su vocal inicial, pues la forma canónica sería * eiñca. Entre iñ y ca no hay dificultad para establecer la segmentación. En el primer caso, estamos ante el morfema de primera persona singular, y en el segundo, ante el morfema de futuro. Así, la frase ino_iñ-ca se traduce por "no seré". El sujeto de esta frase es tácito, pero es correferente con el participio <tapaco $>$.

Luego del verbo principal, viene un complemento circunstancial de lugar que termina en una coma: mo ixll tapaco maiñ polenic, que tiene dos frases bien definidas: la frase participial <mo ixll tapaco $>$ y la frase posposicional <maiñ pol-e_nic $>$. En este fragmento, la frase participial es complemento de la frase posposicional. ¿Cómo lo sabemos? El participio del mochica se 
formaba adjuntando a la raíz del verbo el morfema de participio -(V)pac, pero en este caso particular hay una o al final del participio: mo ixll tapaco maiñ.polenic. En mochica, esa o se insertaba entre el núcleo y su complemento. Así, tapaco resulta cumplir el rol de complemento.

La frase posposicional <maiñ pol-e_nic> es de fácil análisis. El pronombre maiñ es de primera persona y está en genitivo, haciendo las veces de lo que en castellano sería un pronombre posesivo. El nombre pol es la forma posesiva para 'vientre', la -e corresponde al genitivo que es exigido por la posposición nic. La traducción "en mi vientre" corresponde a lo que la oración cristiana nombra "en mi casa». ${ }^{3}$ Esta frase posposicional rige gramaticalmente a la siguiente frase participial.

La frase participial $<$ mo ixll tapaco $>$ tiene como núcleo al participio activo $\langle$ tapaco $>$, que corresponde al verbo irregular tac 'ir'. Ahora, el hecho de que tapaco gobierne la frase mo ixll "este pecado", que no está regida por ninguna otra partícula, nos hace pensar que mo ixll es el objeto de tapaco. Si esto es así, entonces requerimos de otra acepción para tapaco, en tanto verbo transitivo, de modo tal que lo hemos traducido como participio de 'llevar', más que de 'ir'. Tanto 'llevar' como 'ir' son verbos de movimiento, solo que el primero puede tener un objeto, y el segundo, no.

$\mathrm{El}$ análisis descubre una mayor riqueza en la estructura del verbo tac. El participio tapaco está en tercera persona, y el verbo copu-

3. En este caso usamos comillas latinas por no tratarse de un significado inferido. 
lativo de la oración principal, en primera. Anotamos arriba que el sujeto tácito de la oración principal compartía referencia con el participio activo. Esto hace que el participio tapaco sea correferente con el sujeto tácito que traducimos entre paréntesis como (yo). El participio activo de 'llevar' en castellano sería stricto sensu *llevante, que no es un término en uso. Por ese motivo, nuestra traducción final optó por una oración subordinada al sujeto tácito: "yo, que llevo". Tenemos, pues, que la oración «ino_iñ-ca mo ixll tæ-pæco mæiñ pol-e_nic», se traduce: "Yo, que llevo este pecado en mi vientre no seré". Como puede verse, se requiere de un objeto para el verbo principal.

La frase <tzhango maiñ çiec ñop xlloco> es la más interesante. La palabra $<\tilde{n} o p>$ corresponde al verbo 'recibir'. Si recordamos la oración empleada en castellano, ella reza: «no soy digno de recibirte en mi casas. El término $\langle x$ lloco $>$ no se encuentra documentado, pero podemos inferir que su significado es 'digno'. Lo curioso es que la raíz del verbo ñop 'recibir', carece de flexión. Por hipótesis, pensamos que el adjetivo <xlloco $>$ 'digno' podía regir la raíz del verbo ñop 'recibir' sin flexión, otorgándole un sentido de verbo no finito. De este modo, ñop xlloco significaría "digno de recibir". Si este análisis es correcto, entonces, el pronombre <tzhango $>$ de segunda persona singular sería el objeto del verbo ñop 'recibir' y la frase posesiva $\langle$ maiñ çiec $>$, una aposición del pronombre de segunda persona. Así, <ţ̧hango maiñ çiec $\tilde{n} o p>$ se traduciría como "recibirte mi señor", mientras que $<$ trhango maiñ çiec ñop xlloco> se traduciría como "digno de recibirte mi señor". Otra posibilidad es que <iñca> no sea un verbo copulativo, sino más bien, la flexión del verbo ñop 'recibir'. Esta alternativa de análisis tiene, sin embargo, una serie de problemas. 
En primer lugar, la distribución de las flexiones y sus raíces verbales ordena que estos elementos aparezcan juntos, lo cual no es el caso. En segundo lugar, la ausencia de un verbo copulativo haría difícil que el adjetivo $<x$ lloco $>$ 'digno' se integre en la frase. Quizá lo podría hacer como un adverbio, pero no se observa la partícula na que adverbializa adjetivos. Por estas razones descartamos dicha hipótesis.

Ahora bien, algo que vale la pena señalar es el papel que juega la o final en palabras como <tapaco> 'participio activo de llevar' o tzhango 'pronombre de segunda persona'. De la Carrera menciona que la $o$ es un adjetivador. En este caso, <tapaco $>$ hace las veces de complemento de una frase posposicional, que además cuenta con la misma referencia que el sujeto tácito de la oración principal, $y<t z h a n g o>$ es un objeto directo. En este caso, ni el participio activo ni el pronombre de segunda persona se comportan como adjetivos. No estamos de acuerdo con el análisis hecho por Fernando de la Carrera. Determinar la distribución y funciones que cumple la o final es un trabajo que requiere examinar con profundidad una mayor cantidad de textos.

La tercera frase es una oración copulativa, cuyo verbo se encuentra en modo subjuntivo, pues expresa un deseo:

3) santaio tzhæng ssap-ø_mæn ma-iñ, epaca ixll-æss

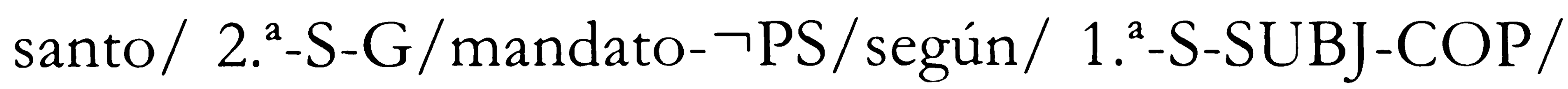
aconsejado/ pecado-PS sea, según tu santo mandato, mi pecado aconsejado o reconvenido La frase santaio tzhang ssap_man se traduce "según tu santo mandato", aun cuando, literalmente, signifique: "según tu santa 
boca". Es curioso que se haya elegido la forma femenina 'santa' como préstamo, para luego adjuntarle la sílaba io. Quizá la elección de la forma femenina del adjetivo santa se haya hecho porque se tenía en mente la traducción de ssap como 'boca', que en castellano es un nombre femenino. En esta frase, la sílaba io cumple con la distribución, en la que había de adjuntarse al adjetivo cuando este era regido por un nombre, máxime si se considera que entre el adjetivo $<$ santaio $>$ y el nombre $\langle$ ssap $>$ está el pronombre en genitivo de segunda persona $<$ tzhang $>$. El subjuntivo está dado por la sílaba ma de <maiñ > y es como una suerte de imperativo. Hemos traducido la palabra epaca como ‘aconsejado' o 'reconvenido' porque por su distribución ocupa la posición de adjetivo del nombre ixllass 'pecado' y, a su vez, porque en Middendorf (1892: 63) aparece epkässäk con el significado de 'consejo' o 'estímulo'. La coma (,) que separa <main̄> de <epaca $>$ confirma que esta última palabra formaba un constituyente con ixllass, en tanto adjetivo. La forma de epkässäk de Middendorf es la de un nombre derivado de verbo, mientras que epaca parece ser el adjetivo de dicho verbo. En epkässäk hay una probable caída de vocal. Finalmente, el nombre ixll-ass se puede analizar como ixll 'pecado' + ass 'morfema de posesión'.

La última frase del texto se encuentra regida por un verbo copulativo que está en un tiempo futuro de obligación:

4) aie-çæn mæiñ moix-ø e-chæm peño, peiñ-na ixll-æss-e_nquich ef-ædo.

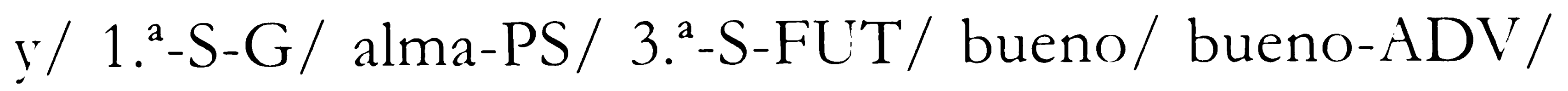
pecado-PS-G-LOC-ABL/ librar-PP.

y mi alma ha de ser buena, buenamente liberada de mis pecados. 
La oración posee dos cláusulas que se dividen por una coma (,). En la primera, que está encabezada por la conjunción copulativa aieçan, hay un nombre <moix> 'alma', en su forma poseída determinado por un pronombre de primera persona en genitivo $<$ maiǹ>. De esta manera, <aieçan maiñ moix> significaría "y mi alma". Este nombre es calificado por el adjetivo <peñ> 'bueno' que se encuentra dentro de una oración con verbo copulativo. Aquí la flexión de tercera persona $<_{e}>$ está unida al morfema de futuro de obligación $<$ cham $>$. Por eso, hemos traducido esta forma verbal por una construcción perifrástica: 'ha de ser'. La primera cláusula, formada por aieçan maiñ moix echam peño se traduce, pues, como "y mi alma ha de ser buena".

La segunda cláusula tiene un carácter adverbial. El adjetivo peiñ 'bueno' es adverbializado por la partícula na. Este adverbio modifica al verbo de la otra cláusula dando un cierto sentido condicional. Esta segunda cláusula tiene un participio pasivo efado 'liberado', el cual rige la frase posposicional ixll-ass-e_nquich 'de (mis) pecados'. Adaptamos este participio a la forma femenina en la traducción al castellano para que haga concordancia con el nombre moix 'alma' de la primera cláusula. El significado de peiñ-na ixll-ass-e_nqu-ich ef-ado sería "buenamente liberada de mis pecados".

\section{Conclusiones}

En este pequeño texto acontece lo que ya es una constante en las interpretaciones que venimos haciendo de los textos mochicas (Salas García 2008). Sucede que las oraciones en mochica no son traducciones estrictas de los textos cristianos. Más bien, se ob- 
serva una enorme libertad en la traducción. Sobre la base de los argumentos arriba expuestos, proponemos la siguiente traducción del texto para administrar el sacramento de la comunión:

Señor, mi señor Jesucristo, yo, que llevo este pecado en mi vientre no seré digno de recibirte, mi señor. Sea, según tu santo mandato, mi pecado aconsejado, y mi alma ha de ser buena, buenamente liberada de mis pecados.

La traducción nos comprueba que se requiere de análisis exhaustivos de los textos para poder de traducirlos, máxime si el propio autor del Arte de la lengua yunga no ofreció los significados de un idioma que pensó que iba a durar por siempre.

\author{
ANEXo 1 \\ Facsímil del texto analizado
}

\title{
Para alminifrar el Sanii) simo Sacramento del Altar. Demirse ronfun dignas, coss
}

soll pæe mxiñ çicc Iclu Chrifo, inoiñca msixllexpxco mxiń polenic, zahango mxin çicc nop xlloco, fancoio tahreng ssap $m x n$ main, epacaixllxss, ajeçæn mæiñ moix $e$. chæn peño, peiñna ixllassen quich efædo. 


\section{REFERENCIAS}

Carrera DAzA, Fernando de la $1644 \quad$ Arte de la lengua yunga de los valles del Obispado de Truxillo del Peru, con un Confessonario, y todas las Oraciones Christianas, traducidas en la lengua, y' otras cosas. Lima: Ioseph de Contreras.

FERNÁNDEZ DE OVIEDO Y' VALDÉS, Gonzalo

1851-1855 [1535-1557] Historia general y natural de las Indias, islas y tierra firme del mar océano. Madrid: Real Academia de la Historia.

JESLITA ANÓNIMO

1968 [¿1594?] «Relación de las costumbres antiguas de los naturales del Pirú». En: Francisco Esteve Barba (ed.). Crónicas peruanas de interés indigena. Madrid: Atlas, pp. 151-189.

MidDENDORF, Ernst Wilhelm

1892 Das Muchik oder die Chimu-Sprache (= Die einheimischen Sprachen Perus, sechster Band). Leipzig: F. A. Brockhaus.

ORÉ, Luis Jerónimo de

1607 Rituale, seu manuale peruanum, et forma brevis administrandi apud Indos sacrosancta Baptismi, Pcenitentia, Eucharistia, Matrimonii et Extrema unctionis Sacramenta. Nápoles: Apud Io. Iacobum Carlinum et Constantinum Vitalem.

Salas García, José Antonio

2008 «La señal de la cruz en la lengua mochica». Lexis, vol. XXXII, n. ${ }^{\circ}$, pp. 321-345. 
JoSE. ANToNio Sal.as Garcia

Concilio Limense, Tercer

1984 [1584] Doctrina christiana, y catecismo para instrucción de los Indios, $y$ de las de mas personas, que han de ser enseñadas en nuestra sancta Fé. Con un confessionario, $y$ otras cosas necessarias para los que doctrinan. Edición facsimilar de la de Antonio Ricardo. Lima: Copé.

Zevallos QuiÑones, Jorge

1948 «Los gramáticos de la lengua yunga». Cuadernos de Estudios del Instituto de Investigaciones Históricas de la Universidad Católica del Perú. III, n. ${ }^{\circ}$ 6, pp. 40-67.

1996 «Exámenes curales de las lenguas yungas en el siglo XVII». Boletin de la Academia Peruana de la Lengua, n. ${ }^{\circ}$ 26, pp. 9-21. 